\title{
Data Summary Report for the 1997 Semiannual Tritium Survey for Fourmile Branch and the F- and H-Area Seeplines
}

by

J. W. Koch II

Westinghouse Savannah River Company

Savannah River Site

Aiken, South Carolina 29808

Exploration Resources

This paper was prepared in connection with work done under the above contract number with the U.S. Department of Energy. By acceptance of this paper, the publisher and/or recipient acknowledges the U. S. Government's right to retain a nonexclusive, royalty-free license in and to any copyright covering this paper, along with the right to reproduce and to authorize others to reproduce all or part of the copyrighted paper.

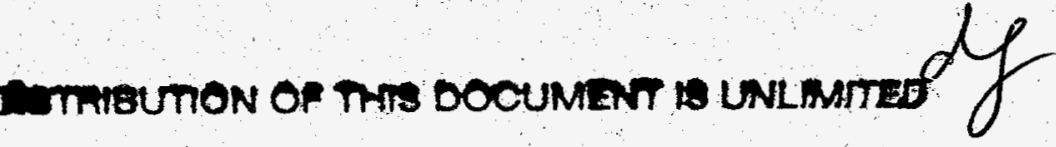




\section{DISCLAIMER}

This report was prepared as an account of work sponsored by an agency of the United States Government. Neither the United States Government nor any agency thereof, nor any of their employees, make any warranty, express or implied, or assumes any legal liability or responsibility for the accuracy, completeness, or usefulness of any information, apparatus, product, or process disclosed, or represents that its use would not infringe privately owned rights. Reference herein to any specific commercial product, process, or service by trade name, trademark, manufacturer, or otherwise does not necescarily constitute or imply its endorsement, recommendation, or favoring by the United States Government or any agency thereof. The views and opinions of authors expressed herein do not necessarily state or reflect those of the United States Government or any agency thereof. 


\section{DISCLAIMER}

Portions of this document may be illegible electronic image products. Images are produced from the best available original document. 
THE ENVIRONMENTAL PROTECTION DEPARTMENT WSRC-TR-97-00414 ENVIRONMENTAL MONITORING SECTION

\title{
Data Summary Report for the 1997 Semiannual Tritium Survey for Fourmile Branch and the F- and H-Area Seeplines
}

(U)

\author{
Prepared by: \\ Environmental Protection Department \\ Environmental Geochemistry Group \\ Westinghouse Savannah River Company \\ Aiken, SC \\ and \\ Exploration Resources, Inc. \\ Athens, GA
}

January 5,1998

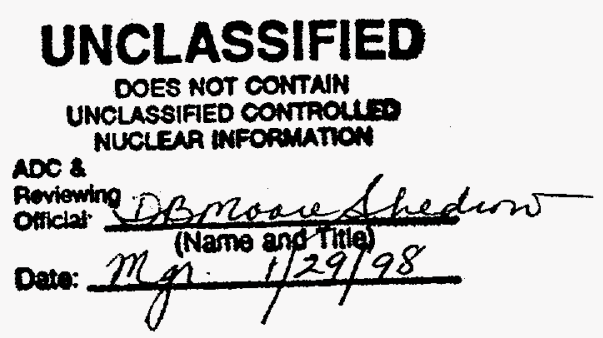




\section{DISCLAIMER}

This report was prepared as an account of work sponsored by an agency of the United States Government. Neither the United States Government nor any agency thereof, nor any of their employees, makes any warranty, express or implied, or assumes any legal liability or responsibility for the accuracy, completeness, or usefulness of any information, apparatus, product, or process disclosed, or represents that its use would not infringe privately owned rights. Reference herein to any specific commercial product, process, or service by trade name, trademark, manufacturer, or otherwise does not necessarily constitute or imply its endorsement, recommendation, or favoring by the United States Government or any agency thereof. The views and opinions of authors expressed herein do not necessarily state or reflect those of the United States Government or any agency thereof.

This report has been reproduced directly from the best available copy.

Available to DOE and DOE contractors from the Office of Scientific and Technical Information, P.O. Box 62, Oak Ridge, TN 37831; prices available from (615) 576-8401.

Available to the public from the National Technical Information Service, U.S. Department of Commerce; 5285 Port Royal Road, Springfield, VA 22161.

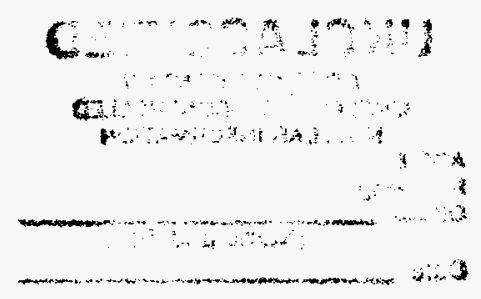




\section{Table of Contents}

List of Tables

List of Acronyms and Abbreviations .......................................................................... vi

Figure

Figure 1. Sampling Locations for Fourmile Branch and the F- and H-Area Seeplines...................................................................... xi

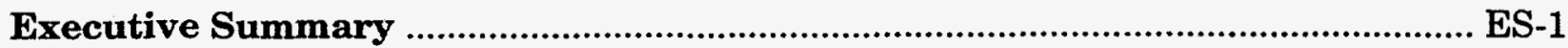

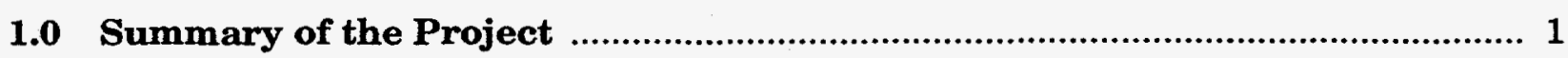

1.1 Objectives ......................................................................................................... 1

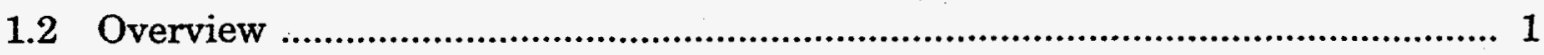

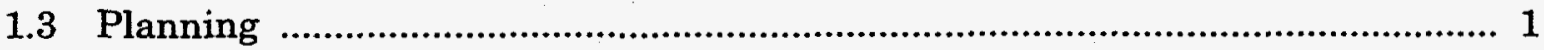

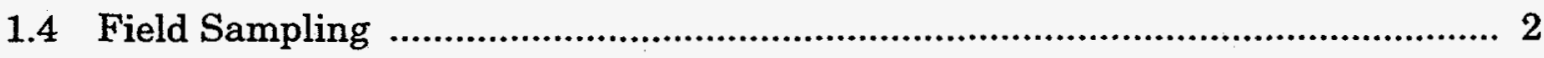

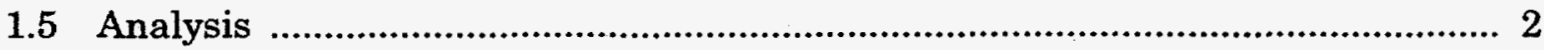

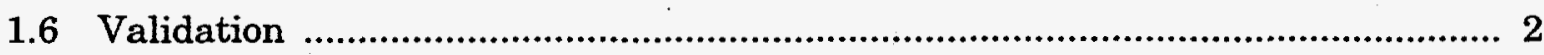

2.0 Data Quality Issues Overview ........................................................................... 3

2.1 Vital Statistics ……........................................................................................ 3

2.2 Program Description ......................................................................................... 4

2.2.1 Verification and Validation Objectives .................................................... 4

2.2.2 Verification and Validation Functions ..................................................... 5

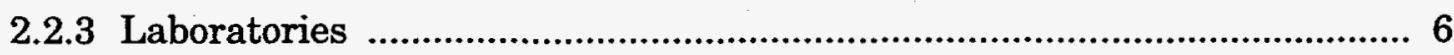

2.3 Data Quality Issues Summary …………........................................................ 7

2.3.1 Missing Data .......................................................................................... 7

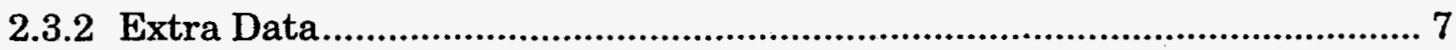

2.3.3 Sample Documentation ............................................................................. 7

2.3.4 Holding Times and Preservation ………..................................................... 7

2.3.5 Analytical Issues .................................................................................. 8

2.3.6 Rejected Data …................................................................................. 8 


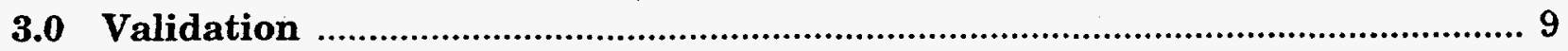

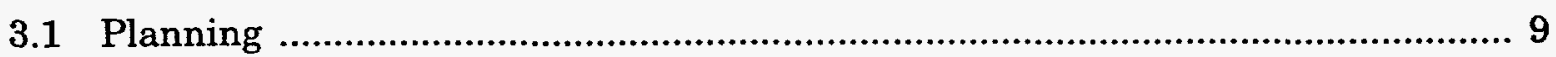

3.1.1 Planned Work ....................................................................................... 9

3.1.2 Production of Chain-of-Custody Forms ............................................ 9

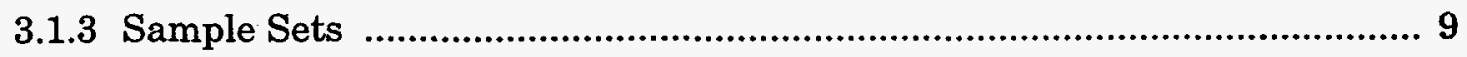

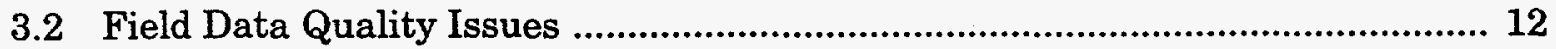

3.2.1 Discrepancies from the Planned Work ......................................... 12

3.2.2 Field Data Sets ......................................................................... 13

3.2.3 Sample Logbook Observations ...................................................... 16

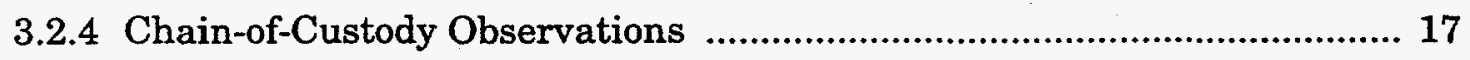

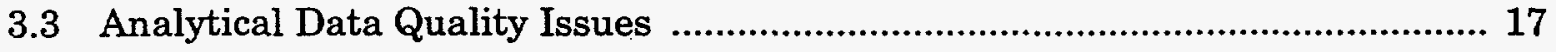

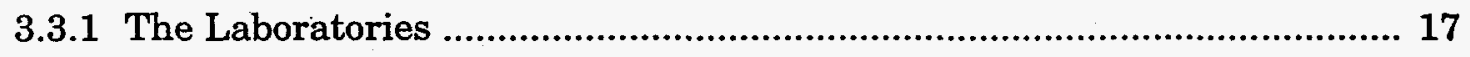

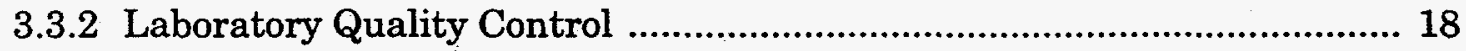

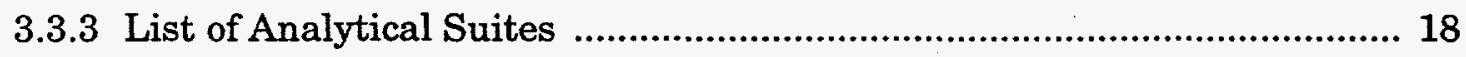

3.3.4 Analytical Data Observations ........................................................ 18

3.4 Verification and Validation Issues .................................................. 18

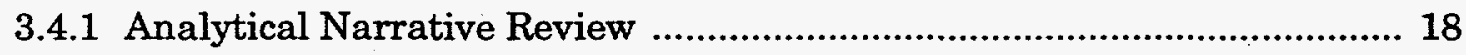

3.4.2 Laboratory Data Records Review ................................................... 19

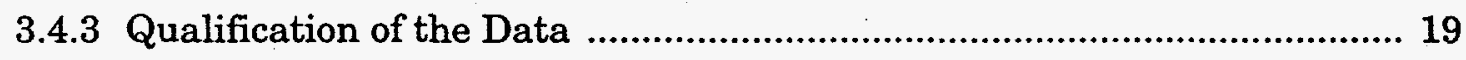

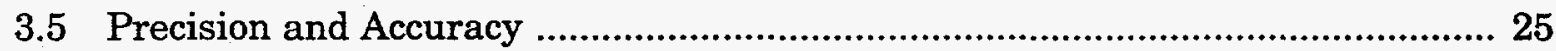

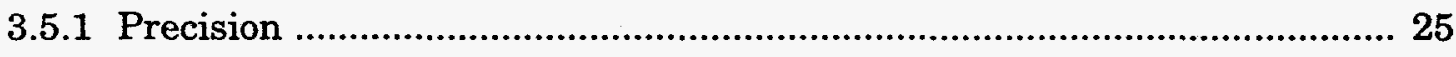

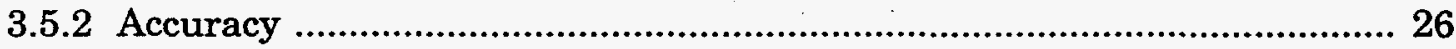

3.5.3 Contamination in Quality Control Samples ...................................... 28

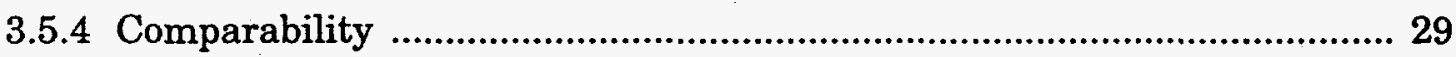

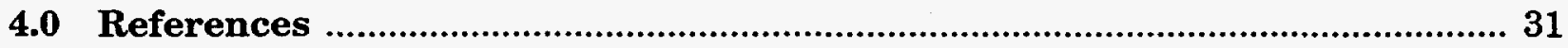

Appendix A: Analytical Methods and Quantitation Limits .............................. A-1

Data Summary Report for the 1997 Semiannual Tritium Survey for Fourmile Branch and the F- and H-Area Seeplines (WSRC-TR-97-00414) 
Appendix B: Laboratory Performance Evaluation Results

B-1

B.1 EPA Performance Evaluation Study Results .................................................... B-1

B.2 EMS Quality Control Standards Results …….................................................. B-2

B.3 Mixed Analyte Evaluation Program ………..................................................... B-2

B.4 EPA Radiological Performance Evaluation Studies............................................. B-3

Appendix C: Formats of the Data Files ...................................................................... C-1

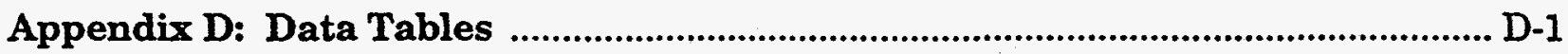

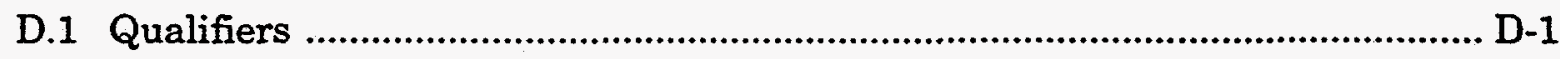

D.2 Number of Qualified Samples ...................................................................... D-4

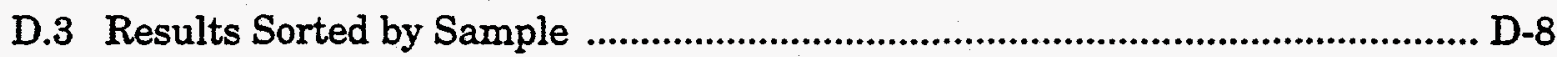

D.4 Results Sorted by Analyte ............................................................................. D-31

Appendix E: Data Management/Administrative Files …........................................ E-1

Appendix F: Glossary ................................................................................................. F-1 
Table $2.1 \quad$ Number of Records With Result Qualifiers for FHST3 .............................. 3

Table 2.2 Number of Records With Result Qualifiers for FHST4 .............................. 3

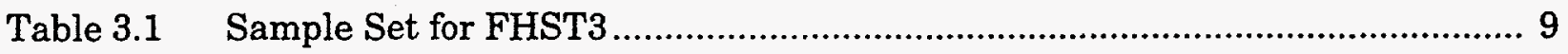

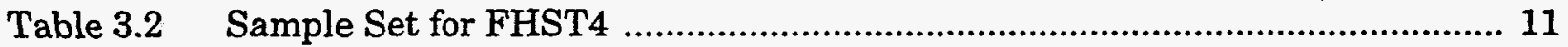

Table 3.3 Planned vs. Actual Stations for FHST3 ............................................... 13

Table 3.4 Planned vs. Actual Stations for FHST4 ................................................... 13

Table 3.5 . Field Data for FHST3 ….................................................................... 13

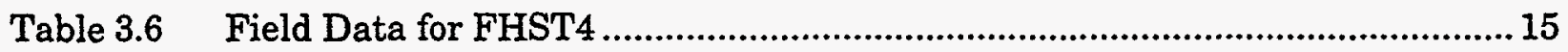

Table 3.7 Matrix Spikes With Sample Concentrations 4 Times Higher Than Nominal Concentration for Samples by EP ................................................ 24

Table 3.8 Relative Percent Differences of Field Duplicates for Water Samples by

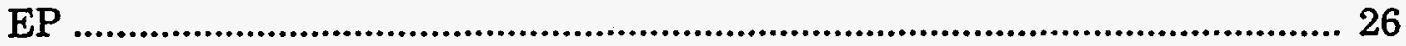

Table 3.9 Laboratory Control Sample Recoveries for Tritium in Water Samples ........ 27

Table 3.10 Matrix Spike Recoveries for Tritium in Water Samples ............................... 28

Table 3.11 Frequency of Detection in Method Blanks for Water Samples by EP ......... 28

Table 3.12 Frequency of Detection in Method Blanks for Water Samples by EM .......... 29

Table 3.13 Split Sample Results for Water Samples. ............................................... 29

Table A.1 Analytical Methods and Mean Quantitation Limits.................................. A-1

Table B.1 Mixed Analyte Performance Evaluation Program Results for MAPEP. 96-S3 for EP and TNU ..................................................................... B-3

Table B.2 Blind-A Results for EP and QR (10/15/96) ............................................. B-4

Table B.3 Blind-B Results for EP and QR (10/15/96) ........................................ B-4

Table B.4 Gamma in Water Results for EP and QR (11/8/96) .............................. B-4

Table B.5 Strontium in Water Results for EP and QR (1/17/97) ............................ B-4

Table B.6 Gross Alpha-Beta in Water Results for EP and QR (1/31/97) ................. B-5

Table B.7 Uranium-Radium in Water Results for EP and QR (2/14/97) ................... B-5

Table C.1 Sample Data Format SAM93 …............................................................. C-1

Table C.2 Sample Bottle Data Format SAM93A .................................................... C-3

Table C.3 Survey Station Data Format STA93 ….............................................. C-3

iv Data Summary Report for the 1997 Semiannual Tritium Survey for Fourmile Branch and the F- and H-Area Seeplines (WSRC-TR-97-00414) 
Table C.4 Chain-of-Custody Data Format COC93 C-4

Table C.5 Analytical Data Format AN95 C-4

Table C.6 Analytical Data Format AN95-R1.B C-7

Table C.7 Analytical Data Format AN95-R2.B C.8

Table C.8 Codes for Laboratory Replicates. C-9

Table C.9 Codes for Fractions. C.9

Table C.10 WSRC Identifier for Groundwater Samples. C-10

Table D.1 Result Qualifiers D-1

Table D.2 Analysis Qualifiers D-1

Table D.3 Bias Qualifiers D-3

Table D.4 Number of Qualified Samples for FHST3 ....................................... D-5

Table D.5 Number of Qualified Samples for FHST4 ............................................ D-5

Table D.6 Number of Analytical Records by Method and Type of Record for FHST3.

Table D.7 Number of Analytical Records by Method and Type of Record for FHST4

Table D.8 Analytes Detected in Environmental Samples for FHST3 D-7

Table D.9 Analytes Detected in Environmental Samples for FHST4 D-7

Table D.10 Results Sorted by Sample for FHST3 D-8

Table D.11 Results Sorted by Sample for FHST4 D-22

Table D.12 Sample Results Sorted by Analyte for FHST3 D-31

Table D.13 Sample Results Sorted by Analyte for FHST4 D-33 
The following acronyms and abbreviations may appear in this Data Summary Report:

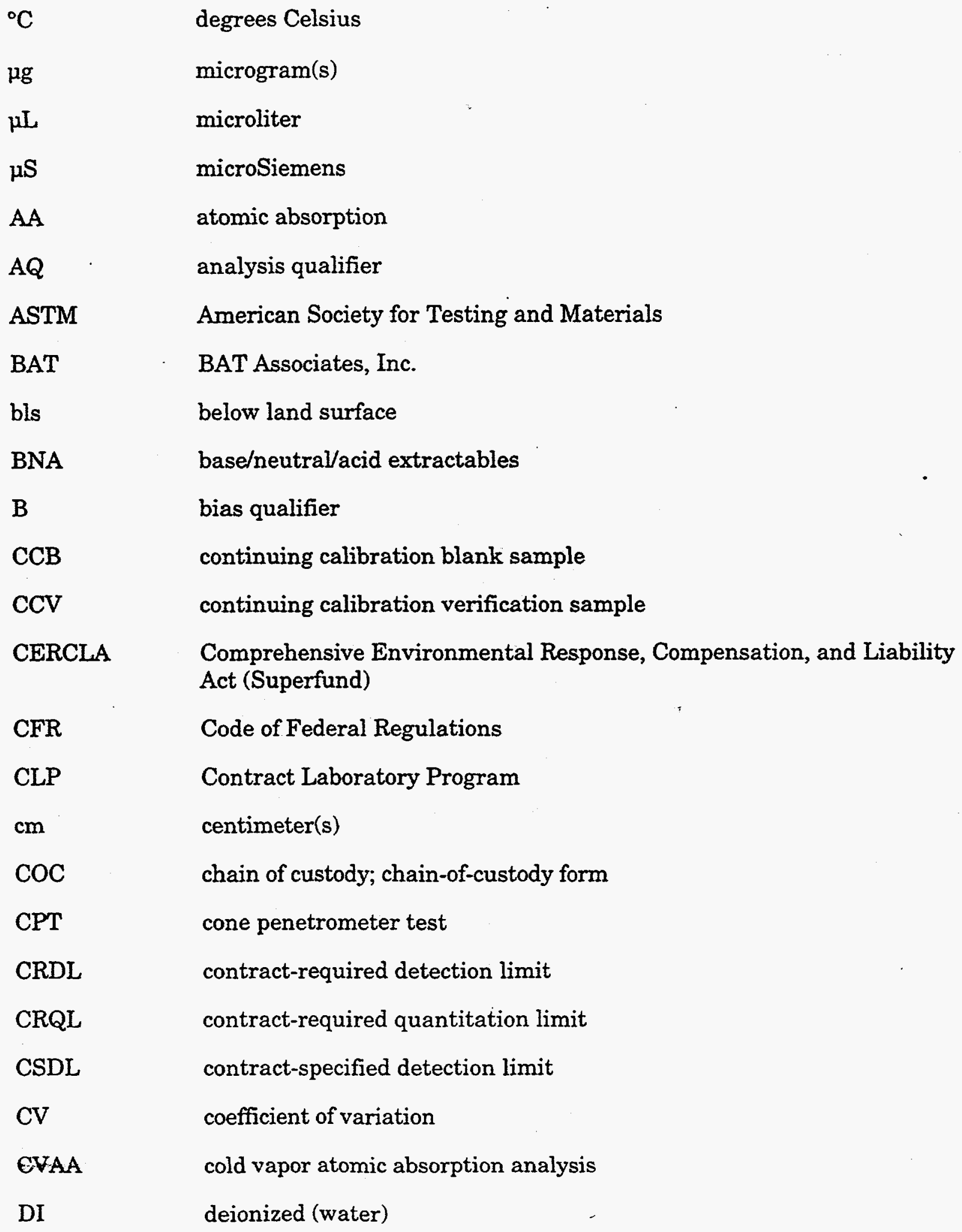




\begin{tabular}{ll} 
DOE & United States Department of Energy \\
dpm & disintegrations per minute \\
DPT & direct push technology \\
DQOs & data quality objectives \\
EDD & electronic data deliverable \\
EGG & Environmental Geochemistry Group \\
Eh & oxidation-reduction potential \\
EM-PPM & parts per million methane equivalent \\
EMSL & EPA's Environmental Monitoring and Support Laboratory \\
EP & Environmental Physics, Inc. \\
EPA & United States Environmental Protection Agency \\
EPD/EMS & Environmental Protection Department/Environmental Monitoring \\
EQL & Section \\
ERA & estimated quantitation limit (for non-radiochemistry analyses) \\
ERD & Environmental Resource Associates \\
ESC & Environmental Restoration Department \\
ExR & expedited site characterization \\
FID & Exploration Resources, Inc. \\
ft & flame ionization detector \\
g & feet \\
FHSR & gram(s) \\
FHST3 & F- and H-Area Seeplines, Radionuclides \\
FHST4 & Third sampling event at the F- and H-Area Seeplines (first quarter 1997) \\
GC & Fourth sampling event at the F- and H-Area Seeplines (third quarter \\
GC/MS & gag) \\
GE & gas chromatography \\
GFAA & gas chromatography/mass spectrometry \\
& \\
\hline
\end{tabular}


GIMS

GMP

GPC

GPR

ICB

ICP

ICS

ICV

ID

IDL

ISA

ISB

kg

$\mathrm{km}$

L

LCS

LDRR

LIMS

LPQL

$\max$.

MCL

MDA

MDL

meq

mg

$\min$.

$\mathrm{mL}$

MRD
Geochemical Information Management System

Groundwater Monitoring Program

gel permeation chromatography

ground penetrating radar

initial calibration blank

inductively coupled plasma (metals analysis)

interference check sample

initial calibration verification

identification

instrument detection limit

ICP interference check sample - interferents only

ICP interference check sample - interferents plus analytes

kilogram

kilometer

liter

laboratory control sample(s)

laboratory data records review

laboratory information management system

lowest practical quantitation limit

maximum

maximum contaminant level

minimum detectable activity

method detection limit

milliequivalents

milligram(s)

minimum

milliliter(s)

mean relative difference 
matrix spike

MSA

method of standard addition

MSD

matrix spike duplicate

MSL

mean sea level

NA

not applicable

NAPL

non-aqueous phase liquid

ng

nanogram(s)

NIST

National Institute of Standards and Technology

NTU

nephelometric turbidity unit

OVA

organic vapor analyzer

PAH

polynuclear aromatic hydrocarbons

PAL

performance acceptance limit

PCB

polychlorinated biphenyl

$\mathrm{pCi}$

picoCurie

PE

performance evaluation

PHA

pulse-height analysis; e.g., gamma PHA

PID

photoionization detector

$\mathrm{ppb}$

parts per billion

ppm

parts per million

QA/QC

quality assurance/quality control

$\mathbf{r}$

correlation coefficient

$\mathrm{RCO}$

Radiological Control Officer

RCRA

Resource Conservation and Recovery Act

Recra

Recra LabNet Philadelphia (formerly Roy F. Weston, Inc., Analytics Division)

RFI/RI

RCRA Facility Investigation/Remedial Investigation

RPD

relative percent difference

$\mathrm{RQ}$

result qualifier

RRT

relative retention time 
RSD

RTW

SAIC

SCDHEC

SGS

SMC

SOP

SOW

SQL

SRS

SRTC

SSC

ssEQL

std. dev.

SW-846

TAL

TCL

TCLP

TIC

TNU

$\mathrm{U}$

USEPA

UTM

VOA

VOC

WHC

WSRC relative standard deviation

retention time window

Science Applications International Corporation

South Carolina Department of Health and Environmental Control

Site Geotechnical Services

sample/method combination

standard operating procedure

statement of work

sample quantitation limit

Savannah River Site

Savannah River Technology Center

site-specific contaminant

sample-specific estimated quantitation limit

standard deviation

EPA's Test Methods for Evaluating Solid Waste

target analyte list

target compound list

toxicity characteristic leaching procedure

tentatively identified compound

Thermo Nutech

unclassified

see EPA

Universal Transverse Mercator Zone 17 Coordinate System

volatile organic analyses

volatile organic compound

Westinghouse Hanford Company

Westinghouse Savannah River Company 


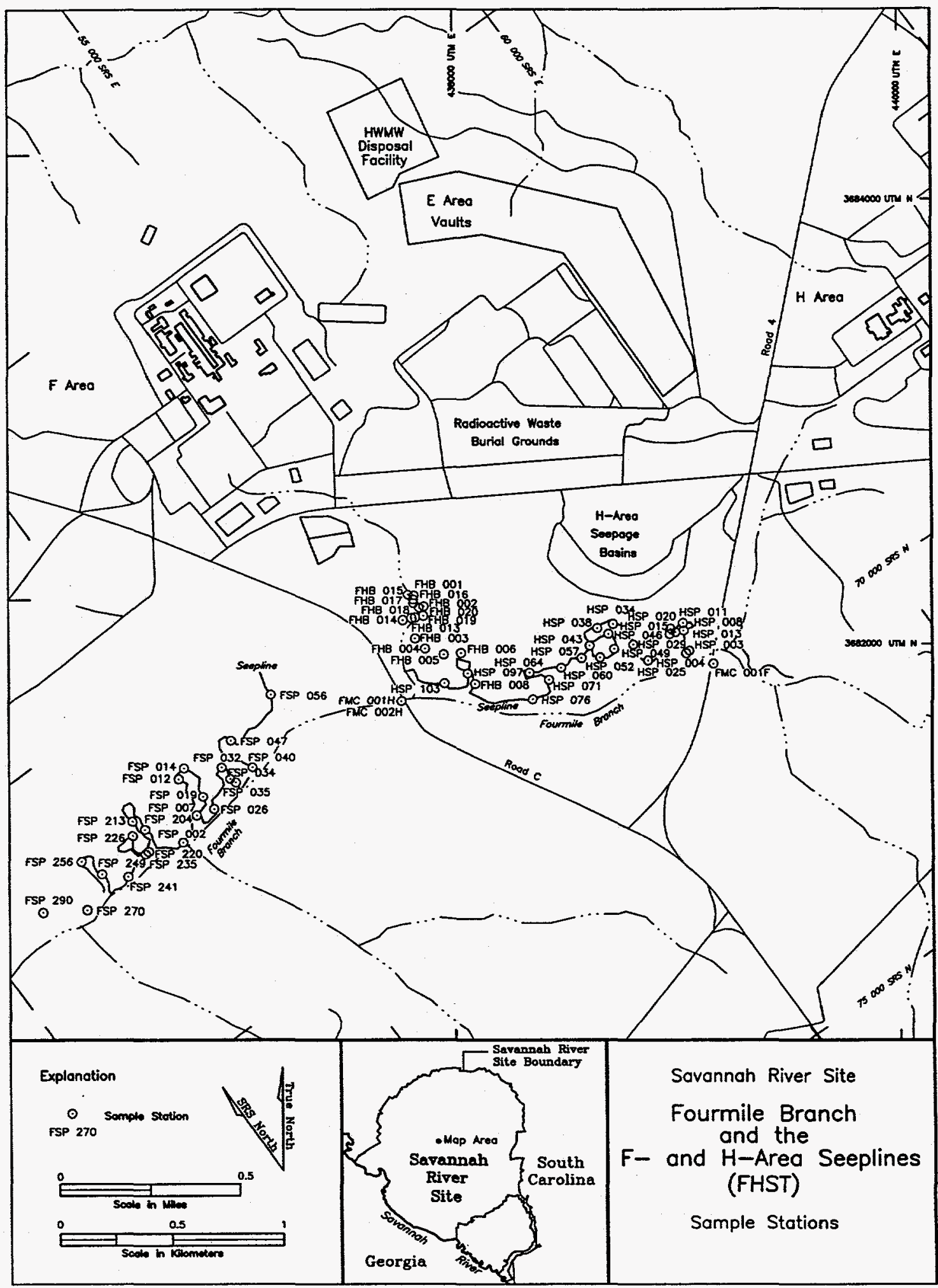

Figure 1. Sampling Locations for Fourmile Branch and the F- and H-Area Seeplines 


\section{Executive Summary}

\section{Purpose}

This report presents a summary of the definitive data validation and verification for the 1997 RFI $^{2}{ }^{1}$ semiannual tritium survey for Fourmile Branch and the F- and H-Area Seeplines. The RFI/RI was performed under the direction of WSRC ESS/Ecology. This report was prepared under the direction of EPD/EMS.

\section{Scope of the Project}

ExR of Athens, GA, validated and verified sample collection, shipping, and laboratory information compiled for this project. The information compiled, reviewed, and maintained includes the following:

- sample documentation

- $\mathrm{COC}$ forms

- sample holding times

- initial and continuing instrument calibration

- analyte identification

- analyte quantitation

- analytical error

- analysis of blanks

- laboratory performance evaluations

- quantitation limits

The validation process began with project mobilization and continued through the delivery of EDDs and this report.

\section{Process and Documentation}

Sample documentation and maintenance of COC were examined by reviewing the field logs and COC forms. See section 3.1.2, Production of Chain-of-Custody Forms, of this report for more information about the COC forms.

1 All acronyms and abbreviations used in this report are defined in the List of Acronyms and Abbreviations (pp. vii-xi). 
Sample holding times were checked by comparing the time between sample collection and analysis with a look-up table of maximum holding times. Analytical instrument calibration was reviewed as part of the LDRR. See section 3.4.2, Laboratory Data Records Review, of this report for more information about the LDRR.

Analyte identification and analyte quantitation were verified as part of the computerized checking of the EDDs, during review of the analytical narratives, and as part of the LDRR. Anomalies were clarified with the laboratories wherever possible, and records not meeting criteria were qualified. See section 3.4, Verification and Validation Issues, of this report for further information.

In evaluating analytical error, percent recoveries for QC samples were reviewed, and the QC sample and associated project sample data were qualified where necessary. Relative percent differences between duplicate sample analyses were calculated. The criteria for qualification are described in section 3.4.3, Qualification of the Data, of this report.

Field-generated blanks (i.e., field blanks, rinsate blanks, and trip blanks) and laboratorygenerated blanks (i.e., method blanks) were examined if included in the sampling plan. See section 3.1, Planning, of this report for an overview of the sampling plan. Laboratorygenerated blanks were analyzed in ratios of more than one for every 20 samples.

Laboratory performance evaluations are detailed in Appendix B of this report.

\section{Semiannual Tritium Survey for Fourmile Branch and the F- and H-Area Seeplines Affiliates}

The project was completed by the following persons and/or organizations:

- Jim Koch, WSRC-ESS/Ecology, Aiken, SC, was the project manager.

- C. Dan Rogers, WSRC-EPD/EMS, Aiken, SC, was the project technical lead.

- Jim Koch, WSRC-ESS/Ecology, Aiken, SC, collected the water samples.

- GE of Charleston, SC, and WSRC's EM Laboratory of Aiken, SC, prepared the definitive-level analytical data.

- ExR of Athens, GA, validated the data and prepared this report. 


\subsection{Summary of the Project}

\subsection{Objective}

The objective of this project is to provide validated data for the semiannual tritium sampling events in Fourmile Branch and the F- and H-Area Seeplines.

\subsection{Overview}

Seepage basins in the $\mathrm{F}$ and $\mathrm{H}$ Areas received low-level radioactive waste effluent from the chemical separation processes in the General Separations Area. The basins retained the effluent to delay its release to the environment. The waste effluent consisted principally of sodium hydroxide, nitric acid, low levels of various radionuclides, and some metals.

Discharges of tritiated water to the seepage basins account for most of the radioactivity.

In 1988 and 1989, the Savannah River Laboratory (now the Savannah River Technology Center) conducted an extensive study aimed at characterizing the shallow groundwater outcropping into Fourmile Branch and its associated seeplines. Researchers measured low $\mathrm{pH}$ values, elevated conductivity, and tritium along the seeplines and determined that contaminants leaching from the F- and H-Area seepage basins were impacting the area.

Discharges to the seepage basins were stopped in 1988, and the basins were capped and sealed in 1990 to minimize the release of contaminants to the environment. Scientists hypothesized that after eliminating the contaminant source, annual rainfall amounts and natural groundwater flow would, over time, dilute and flush the remaining contaminant plume out of the shallow groundwater, which would allow recovery of the wetland systems below the basins.

Quarterly sampling of Fourmile Branch and the F- and H-Area seeplines began in May 1992. Results from the quarterly tritium surveys, in which $\mathrm{pH}$, specific conductance, and tritium are measured, have shown a significant decrease in tritium activities and specific conductance values, and $\mathrm{pH}$ values have increased to more natural ranges ( $\mathrm{pH} 5-6$ ) when compared with 1989.

Prior to 1996, the tritium analyses were conducted by the EMS laboratory. Data validation was required, so the tritium analyses began to be performed by an independent outside laboratory on a semiannual basis.

\subsection{Planning}

Sampling events took place on March 5,6, and 11, 1997, and on September 8, 10, 11, and 17, 1997. One hundred six samples were collected, including duplicates and splits. Concurrent with the sample collection, $\mathrm{pH}$, specific conductance, and water temperatures were measured in the field and recorded in the sample logbooks. 


\subsection{Field Sampling}

During the first sampling event, a total of 63 samples, duplicates, and splits were collected. Forty-three samples were collected during the second sampling event, including duplicates and splits. Tritium results for two additional samples, part of the FHSR project collected on March 10 and 18, 1997, are also reported here.

\subsection{Analysis}

The samples were analyzed for tritium to meet the requirements for definitive-level data.

\subsection{Validation}

Validation and verification activities, using definitive data requirements (EPA, 1993), assessed the quality of the definitive level data for the following issues:

- sample documentation

- maintenance of chain of custody

- adherence to sample holding time requirements

- achievement of contract-required quantitation limits

- analytical instrument calibration

- analyte identification

- analyte quantitation

Evaluation of each laboratory's performance in analyte identification and quantitation included examination of the following:

- analytical error

- contamination of blanks

- laboratory performance evaluation samples

- quantitation limit determination, if applicable 


\subsection{Data Quality Issues Overview}

This section provides a summary of the major points affecting the quality of the data for this project.

\subsection{Vital Statistics}

Of the 138 COCs generated for this project, 108 were used. Twenty-five of the 30 unused COCs were for routine samples that were not utilized, and five were for QC samples (splits or duplicates).

For the FHST3 sampling event, 63 COCs were received from GE. COC forms were not returned for the two split samples sent to the EMS laboratory. Three samples were not taken because the locations were dry, and one sample was voided.

For the FHST4 sampling event, 40 COCs were received from GE. COC forms were not returned for the three split samples sent to the EMS laboratory. Twenty-five samples were not taken because the locations were dry.

Tables 2.1 and 2.2 list the number of sample and $\mathrm{QC}$ records that were assigned $U, J$, or $U J$ result qualifiers after verification and validation were performed.

Table 2.1 Number of Records With Result Qualifiers for FHST3

\begin{tabular}{|l|l|l|l|}
\hline Data Validation Records & $\begin{array}{l}\text { Sample } \\
\text { Records }\end{array}$ & $\begin{array}{l}\text { QC } \\
\text { Records }\end{array}$ & Total \\
\hline Total Number of Analytical Records & 65 & 17 & 82 \\
\hline Qualified Data & \multicolumn{2}{|l|}{} \\
\hline Rejected Analytical Records & 0 & 1 & 1 \\
\hline Result Qualifier $U$ & 0 & 7 & 7 \\
\hline Result Qualifier $J$ & 0 & 0 & 0 \\
\hline Result Qualifier $U J$ & 0 & 0 & 0 \\
\hline
\end{tabular}

Table 2.2 Number of Records With Result Qualifiers for FHST4

\begin{tabular}{|c|c|c|c|}
\hline Data Validation Records & $\begin{array}{l}\text { Sample } \\
\text { Records }\end{array}$ & $\begin{array}{l}\text { QC } \\
\text { Records }\end{array}$ & Total \\
\hline Total Number of Analytical Records & 43 & 22 & 65 \\
\hline \multicolumn{4}{|l|}{ Qualified Data } \\
\hline Rejected Analytical Records & 0 & 1 & 1 \\
\hline Result Qualifier $U$ & 0 & 8 & 8 \\
\hline Result Qualifier $J$ & 1 & 0 & 1 \\
\hline Result Qualifier $U_{J}$ & 0 & 0 & 0 \\
\hline
\end{tabular}




\subsection{Program Description}

This section discusses the validation of the data and gives a brief overview of the laboratories.

\subsubsection{Verification and Validation Objectives}

\section{Data Quality Objectives}

Definitive data (EPA, 1993), have been determined as most appropriate to meet the DQOs of this investigation. Validation and verification activities assessed the data in relation to these standards, especially with regard to the following issues:

- sample documentation

- maintenance of COC

- adherence to sample holding time and preservation requirements

- achievement of contract-required detection limits

- analytical instrument calibration

- analyte identification

- analyte quantitation

Evaluation of each laboratory's performance for analyte identification and quantitation included examination of analytical error, blank contamination, and laboratory performance in the analysis of independent standards.

Each analytical record in the computer data files contains three qualifier fields: result qualifier, analysis qualifier, and bias qualifier. The result qualifier describes the analytical result. The analysis qualifier describes issues arising during the analytical process. The bias qualifier describes whether the result is biased high or low. The laboratories use these fields in reporting the data. During validation and verification of the analytical data, additional qualifiers may be applied to provide additional information about data quality.

\section{Data Quality Levels}

Definitive-level data are used for data collection activities that require a high degree of qualitative and quantitative accuracy for all findings. Rigorous methods of analysis and quality assurance are used for those samples considered essential in making a decision. This data level is intended to give the decision maker a level of confidence to make decisions regarding the following:

- treatment

- disposal

- site remediation and/or removal of pollutants

- health risk or environmental impact

- cleanup verification, pollutant source identification, delineation of contaminants

- other significant decisions where an action level is of concern 
Only analyte-specific methods can be used for definitive-level data.

\subsubsection{Verification and Validation Functions}

The data verification process confirms that the required samples were collected and documented, the required analyses were performed on the samples, and the analytical results were reported correctly. The information evaluated during this process includes the sampling plan, delivery order, sample lists, analyte/compound lists, field logbooks, $\mathrm{COC}$ forms, and analytical results files.

Data reviewers use computer programs and look-up tables to review the computer data files of sample collection, shipping, and analytical data. The data were examined as follows:

- The following fields were checked to ensure that they were not blank: WSRC sample identification number, sample collection date, laboratory receipt date, analysis date, analysis time, analytical method, laboratory code, laboratory sample identification number, analyte code, result units, nominal concentration, number of dilutions, dilution factor, instrument, instrument batch, and analyst's initials.

- The following fields were checked to ensure that the data were within an acceptable range of values: WSRC sample identification number, sample collection date, laboratory receipt date, analysis date, analysis time, analytical result, accuracy, residual weight, number of dilutions, nominal concentration, and bottle number.

- The following fields were checked against a look-up table or a list of valid codes: laboratory code, laboratory duplicate code, analyte code (test name), analytical method, result qualifier, analysis qualifier, analysis bias, result unit, and sample fraction.

The data validation process determines the usefulness of each analytical result based on $\mathrm{QC}$ and method requirements. The information evaluated during this process includes $\mathrm{COC}$ forms, analytical narrative summaries, analytical result data files, and raw result and calibration data.

Data validation involves evaluating requirements in the following QC categories: holding times, sample preservation, instrument calibration, analyte identification/quantitation, blanks (trip, method, and field), laboratory control samples, duplicates (field and laboratory), matrix spikes, surrogates, and internal standards.

Data validation and qualification policies were developed from the following sources: EPA, 1986; EPA, 1988a; EPA, 1988b; EPA, 1990; EPA, 1991b; contract-specific WSRC requirements; and discussions with laboratory personnel.

\section{Data Qualifiers}

When analytical data are validated, the analytical results and the associated QC information are reviewed using criteria specific to the analysis performed. Data qualifiers are used during the data validation process to classify sample data as conforming to $\mathrm{QC}$ requirements.

The qualifiers used for data associated with this project are defined in Appendix $D$. 


\section{Precision}

Precision measures the reproducibility of measurements under a given set of conditions. It is a quantitative measure of the variability of a group of measurements compared to its average value. Precision is reported in terms of the relative percent difference. The analytical results from the field replicate samples provide data on overall measurement precision; analytical results from the laboratory duplicates provide data on analytical precision.

\section{Accuracy}

Accuracy measures the bias in a measurement system; it is difficult to measure for the entire data collection activity. Sources of error are the sampling process, field contamination, preservation, handling, sample matrix, sample preparation, and sample analysis techniques. Sampling accuracy may be assessed by evaluating the results of field blanks and trip blanks. Analytical accuracy may be assessed through the use of known and unknown QC samples, matrix spikes, and method blanks.

\section{Representativeness}

Representativeness expresses the degree to which sample data accurately and precisely represent a characteristic of a population, parameter variations at a sampling point, or an environmental condition. Representativeness is a qualitative parameter that is most concerned with the proper design of the sampling program and is best satisfied by making certain that sampling locations are selected properly and that a sufficient number of samples are collected.

The project support request form states that 63 locations were to be sampled for each event, including six QC samples. For the first event 60 locations were sampled, and an additional five QC samples were taken. Three locations were dry. During the second event, samples were taken from 38 locations plus five QC samples. There were 25 dry locations. Tritium results for two samples from the FHSR project are also reported here.

\section{Completeness}

Completeness is defined as the percentage of measurements made that are judged to be valid measurements. It is important that critical samples are identified and that plans are made to achieve valid data for them. Completeness was not determined for this report.

\section{Comparability}

Comparability is a qualitative parameter expressing the confidence with which one data set can be compared with another. Sample data should be comparable with other measurement data for similar samples and sample conditions. This goal is achieved through using standard techniques to collect and analyze representative samples and through reporting analytical results in appropriate units.

\subsubsection{Laboratories}

The following laboratories generated the analytical data for this project: 
- GE of Charleston, SC, the primary laboratory, provided definitive-level radiological analyses under contract AA07208N.

- EMS/SRS of Aiken, SC, the QC laboratory, provided definitive-level radiological analyses.

\subsection{Data Quality Issues Summary}

This section provides a summary of the major data quality issues identified during the verification and validation process.

\subsubsection{Missing Data}

All planned data for environmental samples were collected and received except from the dry locations. The dry stations for each event are listed below:

$\begin{array}{lll}\text { FHST3 } & \text { FHB-015 } & \text { HSP-064 } \\ \text { FHB-015 } & \text { FHB-016 } & \text { HSP-043 } \\ \text { HSP-038 } & \text { FHB-019 } & \text { HSP-046 } \\ \text { HSP-034 } & \text { FHB-004 } & \text { HSP-011 } \\ \text { FHST4 } & \text { FHB-003 } & \text { HSP-034 } \\ \text { FSP-235 } & \text { FHB-005 } & \text { HSP-038 } \\ \text { FSP-014 } & \text { FHB-001 } & \text { HSP-020 } \\ \text { FSP-032 } & \text { FHB-006 } & \text { HSP-003 } \\ \text { FSP-034 } & \text { FHB-008 } & \text { HSP-004 } \\ \text { FHB-002 } & \text { HSP-060 } & \text { HSP-057 }\end{array}$

\subsubsection{Extra Data}

Tritium results for two samples from the FHSR project (FMC $001 \mathrm{H02}$ and FMC 002H02) are also reported here, at the project manager's request.

\subsubsection{Sample Documentation}

COCs were not available for the two split samples sent to the EMS laboratory during the first sampling event nor for the three split samples sent to the EMS laboratory during the second sampling event.

\subsubsection{Holding Times and Preservation}

No holding times were exceeded for this project.

No cooler temperatures exceeded standards. 


\subsubsection{Analytical Issues}

No significant analytical issues were encountered during verification and validation of the analytical data.

\subsubsection{Rejected Data}

No environmental sample records associated with this project were rejected. One matrix spike was rejected from each sampling event due to high analyte concentration in the environmental samples. See Table 3.8. No environmental sample records required qualification on the basis of these rejected $\mathrm{QC}$ samples. 


\subsection{Planning}

SAIC generated the COCs for this project according to a memo from Jim Koch to Dan Rogers dated December 9, 1996.

\subsubsection{Planned Work}

Samples were to be collected from 63 sampling locations during each of two sampling events, one conducted during first quarter 1997 (FHST3) and one during third quarter 1997 (FHST4).

Sample splits were planned at a frequency of approximately one per 10 samples, to be analyzed for the same parameter as the associated sample.

Samples were to be analyzed for tritium only. The data were validated as definitive-level data.

\subsubsection{Production of Chain-of-Custody Forms}

$\mathrm{COC}$ forms containing the list of requested analyses for each planned sample were printed on waterproof paper. A tear-off stub attached to the $\mathrm{COC}$ form stipulated the sample collection location. Information completed on the COC forms included the following:

- EMS sample identification number from the logbook page for that sample

- laboratory sample identification number (to be completed by the laboratory)

- sample collection date

- shipping information (including the signature of each person handling the sample and the date it was handled)

- cooler number and temperature upon arrival at the analytical laboratory

Sixty-nine COC forms were generated for each sampling event of this project (FHST3 and FHST4).

\subsubsection{Sample Sets}

The following tables list the sample identifiers, sample type, and sample date and time for samples sent to the laboratories. Tritium was the only analysis requested. $A$ in the Station ID indicates a duplicate, and $D$ indicates a split sample.

Table 3.1 Sample Set for FHST3

\begin{tabular}{|l|l|l|l|l|}
\hline Survey Station ID & Sample ID & Laboratory ID & Sample Type & Sample Date and Time \\
\hline FSP 29003 & 110500 & $9703471-01$ & Water & $03 / 05 / 97,09: 00$ \\
\hline FSP 29003A & 110501 & $9703471-45$ & Duplicate & $03 / 05 / 97,09: 05$ \\
\hline FSP 27003 & 110502 & $9703471-03$ & Water & $03 / 05 / 07,09: 10$ \\
\hline
\end{tabular}

Data Summary Report for the 1997 Semiannual Tritium Survey 
Table 3.1 Sample Set for FHST3 (cont.)

\begin{tabular}{|c|c|c|c|c|}
\hline Survey Station ID & Sample W & Laboratory ID & Sample Type & Sample Date and Time \\
\hline FSP 24103 & 110503 & 9703471-04 & Water & $03 / 05 / 97,09: 45$ \\
\hline FSP 24903 & 110504 & 9703471-05 & Water & 03/05/97, 09:55 \\
\hline FSP 25603 & 110505 & $9703471-13$ & Water & $03 / 05 / 97,10: 05$ \\
\hline FSP 21303 & 110506 & $9703471-06$ & Water & $03 / 05 / 97,10: 45$ \\
\hline FSP 22603 & 110507 & 9703471-07 & Water & $03 / 05 / 97,10: 50$ \\
\hline FSP 23503 & 110508 & $9703471-08$ & Water & 03/05/97, 11:00 \\
\hline FSP 20403 & 110509 & $9704590-08$ & Water & $03 / 05 / 97,12: 05$ \\
\hline FSP 00203 & 110510 & 9703471-09 & Water & $03 / 05 / 97,12: 10$ \\
\hline FSP 00703 & 110511 & 9704590-02 & Water & $03 / 05 / 97,12: 15$ \\
\hline FSP 01203 & 110512 & $9703471-10$ & Water & 03/05/97, 12:30 \\
\hline FSP 01403 & 110513 & 9703471-11 & Water & $03 / 05 / 97,12: 45$ \\
\hline FSP 01903 & 110514 & 9704590-09 & Water & 03/05/97, 12:55 \\
\hline FSP 02603 & 110515 & $9704590-10$ & Water & 03/05/97, 13:05 \\
\hline FSP 03203 & 110516 & $9703471-12$ & Water & $03 / 05 / 97,13: 10$ \\
\hline FSP 03403 & 110518 & $9704590-11$ & Water & 03/05/97, 13:15 \\
\hline FSP 04003 & 110519 & $9704590-12$ & Water & $03 / 05 / 97,13: 35$ \\
\hline FSP 03503 & 110520 & 9704590-13 & Water & 03/05/97, 13:35 \\
\hline FSP 04703 & 110521 & $9703471-14$ & Water & $03 / 05 / 97,14: 00$ \\
\hline HSP 07603 & 110522 & $9703471-15$ & Water & $03 / 06 / 97,09: 00$ \\
\hline HSP 07603D & 110523 & 9708776202 & Split & 03/06/97, 09:01 \\
\hline HSP 07103 & 110524 & 9703471-16 & Water & 03/06/97, 09:05 \\
\hline HSP 06003 & 110525 & 9704590-03 & Water & $03 / 06 / 97,09: 15$ \\
\hline HSP 05703 & 110526 & $9703471-17$ & Water & $03 / 06 / 97,09: 25$ \\
\hline HSP 04303 & 110529 & 9704590-04 & Water & $03 / 06 / 97,10: 10$ \\
\hline HSP 05203 & 110530 & $9704590-05$ & Water & $03 / 06 / 97,10: 15$ \\
\hline FSP 22003 & 110531 & $9703471-18$ & Water & $03 / 05 / 97,11: 05$ \\
\hline HSP 04903 & 110532 & 9704590-06 & Water & $03 / 06 / 97,10: 25$ \\
\hline HSP 04603 & 110533 & 9703471-19 & Water & $03 / 06 / 97,10: 30$ \\
\hline HSP 02503 & 110534 & $9703471-20$ & Water & $03 / 06 / 97,10: 50$ \\
\hline HSP 02903 & 110535 & 9703471-21 & Water & $03 / 06 / 97,12: 05$ \\
\hline HSP 02003 & 110536 & 9703471-22 & Water & $03 / 06 / 97,12: 15$ \\
\hline HSP 01503 & 110537 & 9703471-23 & Water & $03 / 06 / 97,12: 30$ \\
\hline HSP 01303 & 110538 & $9703471-24$ & Water & 03/06/97, 12:40 \\
\hline HSP 00803 & 110540 & $9703471-44$ & Water & $03 / 06 / 97,12: 45$ \\
\hline HSP 01103 & 110541 & $9703471-25$ & Water & $03 / 06 / 97,12: 50$ \\
\hline HSP 00303 & 110542 & 9703471-26 & Water & $03 / 06 / 97,13: 00$ \\
\hline HSP 00403 & 110543 & $9703471-27$ & Water & $03 / 06 / 97,13: 05$ \\
\hline HSP 10303 & 110544 & $9703471-28$ & Water & 03/06/97, 13:35 \\
\hline HSP 09703 & 110545 & 9704590-07 & Water & $03 / 06 / 97,13: 40$ \\
\hline FHB 00203 & 110546 & 9703471-29 & Water & $03 / 11 / 97,08: 06$ \\
\hline
\end{tabular}

Data Summary Report for the 1997 Semiannual Tritium Survey for Fourmile Branch and the F- and H-Area Seeplines (WSRC-TR-97-00414) 
Table 3.1 Sample Set for FHST3 (cont.)

\begin{tabular}{|l|l|l|l|l|}
\hline Survey Station W & Sample I & Laboratory ID & Sample Type & Sample Date and Time \\
\hline FHB 00103 & 110547 & $9703471-30$ & Water & $03 / 11 / 97,08: 14$ \\
\hline FHB 01603 & 110548 & $9703471-31$ & Water & $03 / 11 / 97,08: 23$ \\
\hline FHB 01703 & 110550 & $9704590-15$ & Water & $03 / 11 / 97,08: 32$ \\
\hline FHB 01803 & 110551 & $9704590-14$ & Water & $03 / 11 / 97,08: 39$ \\
\hline FHB 02003 & 110552 & $9703471-32$ & Water & $03 / 11 / 97,08: 42$ \\
\hline FHB 01903 & 110553 & $9704590-16$ & Water & $03 / 11 / 97,08: 47$ \\
\hline FHB 01303 & 110554 & $9704590-17$ & Water & $03 / 11 / 97,08: 51$ \\
\hline FHB 01403 & 110555 & $9703471-33$ & Water & $03 / 11 / 97,08: 58$ \\
\hline FHB 01203 & 110556 & $9704590-18$ & Water & $03 / 11 / 97,09: 00$ \\
\hline FHB 00403 & 110557 & $9703471-34$ & Water & $03 / 11 / 97,09: 10$ \\
\hline FHB 00303 & 110558 & $9703471-35$ & Water & $03 / 11 / 97,09: 21$ \\
\hline FHB 00303D & 110559 & 9708776302 & Split & $03 / 11 / 97,09: 23$ \\
\hline FHB 00603 & 110560 & $9703471-36$ & Water & $03 / 11 / 97,09: 50$ \\
\hline FHB 00503 & 110561 & $9703471-37$ & Water & $03 / 11 / 97,09: 55$ \\
\hline FHB 00803 & 110562 & $9703471-38$ & Water & $03 / 11 / 97,10: 08$ \\
\hline FMC 001F03 & 110563 & $9703471-39$ & Water & $03 / 11 / 97,10: 59$ \\
\hline FSP 05603 & 110574 & $9703471-40$ & Water & $03 / 06 / 97,08: 20$ \\
\hline FSP 05603A & 110575 & $9703471-46$ & Duplicate & $03 / 06 / 97,08: 40$ \\
\hline HSP 06403 & 110576 & $9703471-43$ & Water & $03 / 06 / 97,08: 45$ \\
\hline HSP 06403A & 110577 & $9703471-47$ & Duplicate & $03 / 11 / 97,08: 46$ \\
\hline FMC 001H02 & 110609 & $9703289-02$ & Water & $03 / 10 / 97,14: 15$ \\
\hline FMC 002H02 & 110613 & $9703474-01$ & Water & $03 / 18 / 97,15: 00$ \\
\hline
\end{tabular}

Table 3.2 Sample Set for FHST4

\begin{tabular}{|l|l|l|l|l|}
\hline Survey Station ID & Sample ID & Laboratory ID & Sample Type & Sample Date and Time \\
\hline FSP 29004 & 111700 & $9710234-01$ & Water & $09 / 08 / 97,08: 56$ \\
\hline FSP 29004A & 111701 & 9780867502 & Split & $09 / 08 / 97,09: 00$ \\
\hline FSP 27004 & 111702 & $9710234-02$ & Water & $09 / 08 / 97,09: 21$ \\
\hline FSP 25604 & 111703 & $9710234-03$ & Water & $09 / 08 / 97,10: 05$ \\
\hline FSP 24904 & 111704 & $9710234-04$ & Water & $09 / 08 / 97,10: 24$ \\
\hline FSP 24104 & 111705 & $9710234-05$ & Water & $09 / 08 / 97,10: 40$ \\
\hline FSP 22004 & 111707 & $9710234-06$ & Water & $09 / 08 / 97,11: 04$ \\
\hline FSP 22604 & 111708 & $9710234-07$ & Water & $09 / 08 / 97,11: 20$ \\
\hline FSP 21304 & 111709 & $9710880-01$ & Water & $09 / 08 / 97,11: 25$ \\
\hline FSP 20404 & 111710 & $9710880-02$ & Water & $09 / 08 / 97,12: 03$ \\
\hline FSP 00204 & 111711 & $9710234-08$ & Water & $09 / 08 / 97,12: 15$ \\
\hline FSP 00704 & 111712 & $9710234-09$ & Water & $09 / 08 / 97,12: 25$ \\
\hline FSP 01204 & 111713 & $9710234-10$ & Water & $09 / 08 / 97,12: 42$ \\
\hline FSP 01904 & 111715 & $9710880-03$ & Water & $09 / 08 / 97,13: 07$ \\
\hline
\end{tabular}

Data Summary Report for the 1997 Semiannual Tritium Survey for Fourmile Branch and the F- and H-Area Seeplines (WSRC-TR-97-00414) 
Table 3.2 Sample Set for FHST4 (cont.)

\begin{tabular}{|c|c|c|c|c|}
\hline Survey Station ID & Sample ID & Laboratory ID & Sample Type & Sample Date and Time \\
\hline FSP 02604 & 111716 & $9710880-04$ & Water & $09 / 08 / 97,13: 26$ \\
\hline FSP 03504 & 111719 & $9710880-05$ & Water & 09/08/97, 14:07 \\
\hline FSP 04004 & 111720 & $9710880-06$ & Water & $09 / 08 / 97,14: 15$ \\
\hline FSP 04704A & 111721 & $9710234-11$ & Duplicate & 09/10/97, 11:26 \\
\hline FSP 04704 & 111722 & 9780876802 & Split & 09/10/97, 11:25 \\
\hline FSP 05604 & 111723 & 9710234-12 & Water & $09 / 10 / 97,11: 40$ \\
\hline FHB 02004 & 111724 & 9710234-13 & Water & $09 / 10 / 97,12: 10$ \\
\hline FHB 01804 & 111726 & 9710880-07 & Water & $09 / 10 / 97,12: 25$ \\
\hline FHB 01704 & 111727 & $9710880-08$ & Water & $09 / 10 / 97,12: 31$ \\
\hline FHB 01304 & 111730 & 9710880-09 & Water & $09 / 10 / 97,12: 59$ \\
\hline FHB 01204 & 111731 & 9710880-10 & Water & 09/10/97, 13:03 \\
\hline HSP 10304 & 111735 & $9710234-14$ & Water & $09 / 11 / 97,09: 00$ \\
\hline HSP 07604 & 111740 & $9710234-15$ & Water & $09 / 11 / 97,10: 19$ \\
\hline HSP 07104 & 111741 & 9710234-16 & Water & $09 / 11 / 97,10: 34$ \\
\hline HSP 05204 & 111743 & $9710880-11$ & Water & 09/11/97, 11:06 \\
\hline HSP 04904 & 111744 & 9710399-02 & Water & $09 / 11 / 97,11: 15$ \\
\hline FMC 00104 & 111746 & 9710234-19 & Water & $09 / 11 / 97,12: 18$ \\
\hline HSP 00804 & 111747 & 9710399-03 & Water & $09 / 11 / 97,12: 40$ \\
\hline HSP 01504 & 111749 & $9710234-17$ & Water & 09/11/97, 12:56 \\
\hline HSP 01304 & 111750 & 9710234-18 & Water & $09 / 11 / 97,13: 07$ \\
\hline HSP 09704 & 111751 & $9710234-20$ & Water & 09/17/97, 09:00 \\
\hline HSP 09704A & 111752 & 9710399-01 & Duplicate & 09/17/97, 09:02 \\
\hline HSP 02504 & 111756 & $9710234-21$ & Water & $09 / 17 / 97,10: 02$ \\
\hline HSP 02904 & 111757 & $9710234-22$ & Water & 09/17/97, 10:10 \\
\hline FMC 00204 & 111759 & 9710234-23 & Water & 09/17/97, 11:20 \\
\hline FMC 001F04 & 111760 & $9710234-24$ & Water & $09 / 17 / 97,12: 17$ \\
\hline FHB 01404 & 111762 & $9710234-25$ & Water & 09/17/97, 13:35 \\
\hline HSP 10304A & 111763 & 9780867602 & Split & 09/11/97, 09:00 \\
\hline FMC 001F04A & 111764 & $9710234-26$ & Duplicate & $09 / 17 / 97,12: 18$ \\
\hline
\end{tabular}

\subsection{Field Data Quality Issues}

\subsubsection{Discrepancies from the Planned Work}

\section{FHST3}

Samples were not taken for sample IDs 110527, 110528, and 110549 (sampling locations HSP-034, HSP-038, and FHB-015, respectively) during the first sampling event because the holes were dry. Samples 110501, 110575, and 110577 were scheduled to be sent to the EMS laboratory to be analyzed as splits but instead were sent to GE and analyzed as duplicates. Sample 110523 was scheduled to be analyzed at GE as a duplicate but instead was sent to the EMS laboratory as a split.

Data Summary Report for the 1997 Semiannual Tritium Survey for Fourmile Branch and the F- and H-Area Seeplines (WSRC-TR-97-00414) 
During the first sampling event, samples 110501, 110559, 110575, and 100577 were taken from locations other than those planned, as shown in Table 3.3.

Table 3.3. Planned vs. Actual Stations for FHST3

\begin{tabular}{|l|l|l|}
\hline Sample ID & Planned Station & Actual Station \\
\hline 110501 & FSP-002D & FSP-290A \\
\hline 110559 & FMC-002 & FHB-003D \\
\hline 110575 & FSP-204D & FSP-056A \\
\hline 110577 & FHB-001D & HSP-064A \\
\hline
\end{tabular}

\section{FHST4}

Samples were not taken for sample IDs 111706 (FSP-235), 111714 (FSP-014), 111717 (FSP032), 111718 (FSP-034), 111725 (FHB-002), 111728 (FHB-015 and FHB-016), 111729 (FHB-019), 111732 (FHB-004 and FHB-003), 111733 (FHB-005), 111734 (FHB-001), 111736 (FHB-006), 111737 (FHB-008), 111738 (HSP-060), 111739 (HSP-064), 111742 (HSP-043), 111745 (HSP-046), 111748 (HSP-011), 111753 (HSP-034), 111754 (HSP-038), 111755 (HSP-020), 111758 (HSP-003 and HSP-004), and 111761 (HSP-057) because the holes were dry.

For sample ID 111744, the actual station was written incorrectly in the field logbook as FSP-049; it should have been HSP-049. Samples 111752 and 111763 were taken from locations other than those planned, as shown in Table 3.4.

Table 3.4. Planned vs. Actual Stations for FHST4

\begin{tabular}{|l|l|l|}
\hline Sample ID & Planned Station & Actual Station \\
\hline 111752 & HSP-008A & HSP-097A \\
\hline 111763 & FHB-034A & HSP-103A \\
\hline
\end{tabular}

\subsubsection{Field Data Sets}

The following tables list the sample identifiers, sample date and time, and the $\mathrm{pH}$, turbidity, and conductivity readings taken at the time of sampling. $A$ in the Station ID indicates a duplicate, and $D$ indicates a split sample.

Table 3.5 Field Data for FHST3

\begin{tabular}{|l|l|l|l|l|l|}
\hline $\begin{array}{l}\text { Survey } \\
\text { Station ID }\end{array}$ & $\begin{array}{l}\text { Sample } \\
\mathbf{W}\end{array}$ & $\begin{array}{l}\text { Sample Date and } \\
\text { Time }\end{array}$ & $\mathbf{p H}$ & $\begin{array}{l}\text { Conductivity } \\
(\boldsymbol{\mu m h o s})\end{array}$ & $\begin{array}{l}\text { Water } \\
\text { Temperature }\left({ }^{\circ} \mathbf{C}\right)\end{array}$ \\
\hline FSP 29003 & 110500 & $03 / 05 / 97,09: 00$ & 4.19 & 52 & 14 \\
\hline FSP 29003A & 110501 & $03 / 05 / 97,09: 05$ & 4.19 & 52 & 14 \\
\hline FSP 27003 & 110502 & $03 / 05 / 07,09: 10$ & 4.34 & 137 & 14.1 \\
\hline FSP 24103 & 110503 & $03 / 05 / 97,09: 45$ & 5.52 & 128 & 15.1 \\
\hline FSP 24903 & 110504 & $03 / 05 / 97,09: 55$ & 5.20 & 64 & 14.6 \\
\hline FSP 25603 & 110505 & $03 / 05 / 97,10: 05$ & 5.42 & 48 & 14.8 \\
\hline
\end{tabular}

Data Summary Report for the 1997 Semiannual Tritium Survey for Fourmile Branch and the F- and H-Area Seeplines (WSRC-TR-97-00414) 
Table 3.5 Field Data for FHST3 (cont.)

\begin{tabular}{|c|c|c|c|c|c|}
\hline $\begin{array}{l}\text { Survey } \\
\text { Station ID }\end{array}$ & $\begin{array}{l}\text { Sample } \\
\text { D }\end{array}$ & $\begin{array}{l}\text { Sample Date and } \\
\text { Time }\end{array}$ & $\mathbf{p H}$ & $\begin{array}{l}\text { Conductivity } \\
\text { (pmhos) }\end{array}$ & $\begin{array}{l}\text { Water } \\
\text { Temperature }\left({ }^{\circ} \mathrm{C}\right)\end{array}$ \\
\hline FSP 21303 & 110506 & $03 / 05 / 97,10: 45$ & 5.42 & 39 & 14.4 \\
\hline FSP 22603 & 110507 & $03 / 05 / 97,10: 50$ & 5.46 & 210 & 15.7 \\
\hline FSP 23503 & 110508 & $03 / 05 / 97,11: 00$ & 5.73 & 62 & 14.7 \\
\hline FSP 20403 & 110509 & $03 / 05 / 97,12: 05$ & 4.55 & 443 & 19.4 \\
\hline FSP 00203 & 110510 & $03 / 05 / 97,12: 10$ & 6.39 & 81 & 19.1 \\
\hline FSP 00703 & 110511 & $03 / 05 / 97,12: 15$ & 6.28 & 236 & 22.3 \\
\hline FSP 01203 & 110512 & $03 / 05 / 97,12: 30$ & 5.74 & 42 & 15.5 \\
\hline FSP 01403 & 110513 & $03 / 05 / 97,12: 45$ & 5.24 & 21 & 16.9 \\
\hline FSP 01903 & 110514 & $03 / 05 / 97,12: 55$ & 4.26 & 901 & 16.0 \\
\hline FSP 02603 & 110515 & 03/05/97, 13:05 & 4.53 & 1350 & 14.7 \\
\hline FSP 03203 & 110516 & 03/05/97, 13:10 & 5.36 & 31 & 15.7 \\
\hline FSP 03403 & 110518 & $03 / 05 / 97,13: 15$ & 4.40 & 416 & 15.1 \\
\hline FSP 04003 & 110519 & $03 / 05 / 97,13: 35$ & 4.54 & 1137 & 14.9 \\
\hline FSP 03503 & 110520 & $03 / 05 / 97,13: 35$ & 4.42 & 842 & 16.4 \\
\hline FSP 04703 & 110521 & $03 / 05 / 97,14: 00$ & 5.22 & 46 & 16.3 \\
\hline HSP 07603 & 110522 & $03 / 06 / 97,09: 00$ & 6.26 & 110 & 15.2 \\
\hline HSP 07603D & 110523 & $03 / 06 / 97,09: 01$ & $N_{R}^{a}$ & NR & NR \\
\hline HSP 07103 & 110524 & $03 / 06 / 97,09: 05$ & 6.45 & 92 & 13.6 \\
\hline HSP 06003 & 110525 & 03/06/97, 09:15 & 6.01 & 164 & 13.4 \\
\hline HSP 05703 & 110526 & $03 / 06 / 97,09: 25$ & 6.08 & 99 & 14.2 \\
\hline HSP 04303 & 110529 & $03 / 06 / 97,10: 10$ & 6.49 & 104 & 13.1 \\
\hline HSP 05203 & 110530 & $03 / 06 / 97,10: 15$ & 5.87 & 308 & 13.7 \\
\hline FSP 22003 & 110531 & 03/05/97, 11:05 & 5.03 & 180 & 14.6 \\
\hline HSP 04903 & 110532 & $03 / 06 / 97,10: 25$ & 6.00 & 100 & 14.2 \\
\hline HSP 04603 & 110533 & $03 / 06 / 97,10: 30$ & 6.10 & 136 & 13.4 \\
\hline HSP 02503 & 110534 & $03 / 06 / 97,10: 50$ & 5.41 & 43 & 14.0 \\
\hline HSP 02903 & 110535 & 03/06/97, 12:05 & 5.39 & 45 & 13.7 \\
\hline HSP 02003 & 110536 & $03 / 06 / 97,12: 15$ & 5.69 & 63 & 14.7 \\
\hline HSP 01503 & 110537 & $03 / 06 / 97,12: 30$ & 5.69 & 91 & 14.3 \\
\hline HSP 01303 & 110538 & $03 / 06 / 97,12: 40$ & 6.38 & 119 & 13.9 \\
\hline HSP 00803 & 110540 & $03 / 06 / 97,12: 45$ & 6.56 & 125 & 13.8 \\
\hline HSP 01103 & 110541 & 03/06/97, 12:50 & 5.65 & 33 & 14.2 \\
\hline HSP 00303 & 110542 & 03/06/97, 13:00 & 6.64 & 184 & 15.1 \\
\hline HSP 00403 & 110543 & 03/06/97, 13:05 & 6.57 & 96 & 14.7 \\
\hline HSP 10303 & 110544 & 03/06/97, 13:35 & 5.45 & 68 & 14.8 \\
\hline HSP 09703 & 110545 & $03 / 06 / 97,13: 40$ & 6.10 & 87 & 16.3 \\
\hline FHB 00203 & 110546 & 03/11/97, 08:06 & 4.98 & 32 & 14.5 \\
\hline
\end{tabular}

a NR - not recorded. Data should be identical to that of parent sample.

Data Summary Report for the 1997 Semiannual Tritium Survey for Fourmile Branch and the F- and H-Area Seeplines (WSRC-TR-97-00414) 
Table 3.5 Field Data for FHST3 (cont.)

\begin{tabular}{|l|l|l|l|l|l|}
\hline $\begin{array}{l}\text { Survey } \\
\text { Station ID }\end{array}$ & $\begin{array}{l}\text { Sample } \\
\text { ID }\end{array}$ & $\begin{array}{l}\text { Sample Date and } \\
\text { Time }\end{array}$ & pH & $\begin{array}{l}\text { Conductivity } \\
(\boldsymbol{\mu} \text { mhos })\end{array}$ & $\begin{array}{l}\text { Water } \\
\text { Temperature }\left({ }^{\circ} \mathrm{C}\right)\end{array}$ \\
\hline FHB 00103 & 110547 & $03 / 11 / 97,08: 14$ & 5.63 & 38 & 14.3 \\
\hline FHB 01603 & 110548 & $03 / 11 / 97,08: 23$ & 5.72 & 53 & 13.7 \\
\hline FHB 01703 & 110550 & $03 / 11 / 97,08: 32$ & 5.35 & 42 & 13.7 \\
\hline FHB 01803 & 110551 & $03 / 11 / 97,08: 39$ & 6.12 & 73 & 14.3 \\
\hline FHB 02003 & 110552 & $03 / 11 / 97,08: 42$ & 6.13 & 26 & 14.6 \\
\hline FHB 01903 & 110553 & $03 / 11 / 97,08: 47$ & 4.86 & 41 & 14.1 \\
\hline FHB 01303 & 110554 & $03 / 11 / 97,08: 51$ & 4.98 & 27 & 14.4 \\
\hline FHB 01403 & 110555 & $03 / 11 / 97,08: 58$ & 4.98 & 31 & 15.9 \\
\hline FHB 01203 & 110556 & $03 / 11 / 97,09: 00$ & 4.75 & 32 & 15.7 \\
\hline FHB 00403 & 110557 & $03 / 11 / 97,09: 10$ & 5.11 & 31 & 14.5 \\
\hline FHB 00303 & 110558 & $03 / 11 / 97,09: 21$ & 5.15 & 27 & 14.2 \\
\hline FHB 00303D & 110559 & $03 / 11 / 97,09: 23$ & 5.15 & 27 & 14.2 \\
\hline FHB 00603 & 110560 & $03 / 11 / 97,09: 50$ & 5.58 & 34 & 14.5 \\
\hline FHB 00503 & 110561 & $03 / 11 / 97,09: 55$ & 5.47 & 37 & 13.7 \\
\hline FHB 00803 & 110562 & $03 / 11 / 97,10: 08$ & 5.27 & 20 & 14.6 \\
\hline FMC 001F03 & 110563 & $03 / 11 / 97,10: 59$ & 6.57 & 55 & 19.2 \\
\hline FSP 05603 & 110574 & $03 / 06 / 97,08: 20$ & 5.47 & 71 & 14.1 \\
\hline FSP 05603A & 110575 & $03 / 06 / 97,08: 40$ & 5.47 & 71 & 14.1 \\
\hline HSP 06403 & 110576 & $03 / 06 / 97,08: 45$ & 5.12 & 28 & 14.2 \\
\hline HSP 06403A & 110577 & $03 / 06 / 97,08: 46$ & NR & NR & NR \\
\hline FMC 001H & 110609 & $03 / 10 / 97,14: 15$ & 7.73 & 34 & $70.3^{\circ} \mathrm{F}$ \\
\hline FMC 002H & 110613 & $03 / 18 / 97,15: 00$ & 6.5 & 53 & $\mathrm{~F}$ \\
\hline
\end{tabular}

\section{Table 3.6 Field Data for FHST4}

\begin{tabular}{|l|l|l|l|l|l|}
\hline $\begin{array}{l}\text { Survey } \\
\text { Station ID }\end{array}$ & $\begin{array}{l}\text { Sample } \\
\text { WD }\end{array}$ & $\begin{array}{l}\text { Sample Date and } \\
\text { Time }\end{array}$ & $\mathbf{p H}$ & $\begin{array}{l}\text { Conductivity } \\
(\boldsymbol{\mu m b o s})\end{array}$ & $\begin{array}{l}\text { Water } \\
\text { Temperature }\left({ }^{\circ} \mathbf{C}\right)\end{array}$ \\
\hline FSP 29004 & 111700 & $09 / 08 / 97,08: 56$ & 4.94 & 29 & 19.4 \\
\hline FSP 29004A & 111701 & $09 / 08 / 97,09: 00$ & NRb & NR & NR \\
\hline FSP 27004 & 111702 & $09 / 08 / 97,09: 21$ & 4.98 & 35 & 17.4 \\
\hline FSP 25604 & 111703 & $09 / 08 / 97,10: 05$ & 6.13 & 156 & 18.7 \\
\hline FSP 24904 & 111704 & $09 / 08 / 97,10: 24$ & 5.42 & 39 & 23.6 \\
\hline FSP 24104 & 111705 & $09 / 08 / 97,10: 40$ & 5.91 & 254 & 21.7 \\
\hline FSP 22004 & 111707 & $09 / 08 / 97,11: 04$ & 5.91 & 146 & 21.7 \\
\hline FSP 22604 & 111708 & $09 / 08 / 97,11: 20$ & 5.85 & 79 & 22.8 \\
\hline FSP 21304 & 111709 & $09 / 08 / 97,11: 25$ & 4.02 & 477 & 21.5 \\
\hline FSP 20404 & 111710 & $09 / 08 / 97,12: 03$ & 4.49 & 138 & 22.6 \\
\hline
\end{tabular}

b NR - not recorded. Data should be identical to that of parent sample.

Data Summary Report for the 1997 Semiannual Tritium Survey for Fourmile Branch and the F- and H-Area Seeplines (WSRC-TR-97-00414) 
Table 3.6 Field Data for FHST4 (cont.)

\begin{tabular}{|c|c|c|c|c|c|}
\hline $\begin{array}{l}\text { Survey } \\
\text { Station ID }\end{array}$ & $\begin{array}{l}\text { Sample } \\
\text { ID }\end{array}$ & $\begin{array}{l}\text { Sample Date and } \\
\text { Time }\end{array}$ & $\mathbf{p H}$ & $\begin{array}{l}\text { Conductivity } \\
\text { ( } \mu \text { mhos) }\end{array}$ & $\begin{array}{l}\text { Water } \\
\text { Temperature }\left({ }^{\circ} \mathrm{C}\right)\end{array}$ \\
\hline FSP 00204 & 111711 & $09 / 08 / 97,12: 15$ & 6.8 & 78.3 & 22.9 \\
\hline FSP 00704 & 111712 & $09 / 08 / 97,12: 25$ & 6.13 & 535 & 20.1 \\
\hline FSP 01204 & 111713 & $09 / 08 / 97,12: 42$ & 5.6 & 36 & 24.7 \\
\hline FSP 01904 & 111715 & 09/08/97, 13:07 & 4.02 & 816 & 22.2 \\
\hline FSP 02604 & 111716 & 09/08/97, 13:26 & 6.44 & 686 & 23.4 \\
\hline FSP 03504 & 111719 & 09/08/97, 14:07 & 3.99 & 1261 & 22.6 \\
\hline FSP 04004 & 111720 & $09 / 08 / 97,14: 15$ & 4.16 & 716 & 24.5 \\
\hline FSP 04704A & 111721 & 09/10/97, 11:26 & 5.28 & 39.3 & 22.4 \\
\hline FSP 04704 & 111722 & 09/10/97, 11:25 & NR & NR & NR \\
\hline FSP 05604 & 111723 & $09 / 10 / 97,11: 40$ & 3.1 & 45 & 22.1 \\
\hline FHB 02004 & 111724 & $09 / 10 / 97,12: 10$ & 5.29 & 43 & 22.2 \\
\hline FHB 01804 & 111726 & $09 / 10 / 97,12: 25$ & 4.99 & 34 & 21.1 \\
\hline FHB 01704 & 111727 & $09 / 10 / 97,12: 31$ & 5.05 & 42 & 22.4 \\
\hline FHB 01304 & 111730 & 09/10/97, 12:59 & 4.58 & 51 & 22.3 \\
\hline FHB 01204 & 111731 & 09/10/97, 13:03 & 5.31 & 42 & 20.5 \\
\hline HSP 10304 & 111735 & 09/11/97, 09:00 & 5.01 & 119 & 21.4 \\
\hline HSP 07604 & 111740 & 09/11/97, 10:19 & 6.20 & 65 & 20.4 \\
\hline HSP 07104 & 111741 & $09 / 11 / 97,10: 34$ & 6.42 & 151 & 21.2 \\
\hline HSP 05204 & 1.11743 & 09/11/97, 11:06 & 6.24 & 380 & 21.6 \\
\hline HSP 04904 & 111744 & 09/11/97, 11:15 & 5.75 & 84 & 22.0 \\
\hline FMC 00104 & 111746 & $09 / 11 / 97,12: 18$ & 6.53 & 64 & 25.3 \\
\hline HSP 00804 & 111747 & $09 / 11 / 97,12: 40$ & 5.96 & 93 & 21.9 \\
\hline HSP 01504 & 111749 & 09/11/97, 12:56 & 5.73 & 147 & 22.8 \\
\hline HSP 01304 & 111750 & 09/11/97, 13:07 & 5.98 & 79 & 22.7 \\
\hline HSP 09704 & 111751 & $09 / 17 / 97,09: 00$ & 6.09 & 137 & 20.7 \\
\hline HSP 09704A & 111752 & 09/17/97, 09:02 & NR & NR & $\mathrm{NR}$ \\
\hline HSP 02504 & 111756 & 09/17/97, 10:02 & 6.27 & 117 & 22.6 \\
\hline HSP 02904 & 111757 & 09/17/97, 10:10 & 6.27 & 47 & 22.4 \\
\hline FMC 00204 & 111759 & 09/17/97, 11:20 & 6.10 & 66 & 24.1 \\
\hline FMC 001F04 & 111760 & 09/17/97, 12:17 & 6.84 & 62 & 24.4 \\
\hline FHB 01404 & 111762 & 09/17/97, 13:35 & 3.48 & 33 & 20.7 \\
\hline HSP 10304A & 111763 & 09/11/97,09:00 & NR & NR & NR \\
\hline FMC 001F04A & 111764 & 09/17/97, 12:18 & NR & NR & NR \\
\hline
\end{tabular}

\subsubsection{Sample Logbook Observations}

\section{FHST3}

During the first sampling event, no entry was made for sampling location FMC-002.

Sample ID 110517 was not used; the field logbook pages were crossed out as omitted.

Pages in the field logbook for sample ID 110539 (station HSP-011) were voided, and that

Data Summary Report for the 1997 Semiannual Tritium Survey for Fourmile Branch and the F- and H-Area Seeplines (WSRC-TR-97-00414) 
station was sampled as sample ID 110541. Sample logbook pages for sample ID 110573 were used to record calibration of $\mathrm{pH}$ and conductivity meters.

Sample logbook entries for sample IDs 110500, 110501, and 110506 note that the sample was taken by dipping with the sample bottle. The entry for sample 110556 (FHB-012) notes that it is a stream location.

There were no sample logbook observations that affected data quality.

\section{FHST4}

For sample ID 111708, the sampler noted that it was not very wet in the seepline, much dryer than usual.

The sampler noted for sample ID 111710 that a bucket was present.

The observations that the bucket and seepline were dry were made for sample ID 111717.

For sample ID 111755, the sampler noted that the sampling location was damp, but no water was seeping into the augered hole.

For sample ID 111727, the sampler noted that the first location where an attempt was made to obtain field measurements was dry. The location was moved $20 \mathrm{ft}$, and field measurements were obtained.

The sampler noted for sample ID 111735 that there was lots of water in the bucket.

For sample ID 111761, the sampler noted that the sampling location was moist.

There were no sample logbook observations that affected data quality.

\subsubsection{Chain-of-Custody Observations}

\section{FHST3}

Chains of custody for samples 110523 and 110559, split samples from the first sampling event that were sent to EMS, were not returned from the laboratory.

\section{FHST4}

Chains of custody for samples 111701,111722 , and 111763, split samples from the second sampling event that were sent to EMS, were not returned from the laboratory.

\subsection{Analytical Data Quality Issues}

\subsubsection{The Laboratories}

The samples were analyzed by GE under contract AA07208N. The laboratory has been certified by SCDHEC. The splits were analyzed by the EMS laboratory. 


\subsubsection{Laboratory Quality Control}

The laboratories follow their own QA/QC plans, which are designed to measure and document the accuracy and precision for the various sample control and analytical methods it performs. The laboratories are guided by published method-specific $\mathrm{QC}$ requirements as well as other regulatory and contract-required $\mathrm{QC}$ procedures.

\subsubsection{List of Analytical Suites}

Tritium was the only analyte requested in both sampling events. See Appendix $A$ for a listing of the analytical methods and the lab's reporting of MDAs.

\subsubsection{Analytical Data Observations}

The data are final and complete except as noted in this subsection. Data validation is also complete.

Some of the data did not meet all the criteria listed in EPA, 1993, as noted below:

- Field measurements are designed to meet the criteria for screening-level data and they are not analyte specific. Therefore, definitive data criteria are not applicable.

- Analytical error determination (a measurement of method precision) was not calculated; however, precision can be evaluated by referring to the tables in section 3.5, Precision and Accuracy, of this report.

- Total measurement error determination (measurement of overall precision from sample acquisition through analysis) was not performed because it requires independently collected samples from the same location, and this practice does not fit into the scope of the project work plan.

- No adjustments to sample values were made for bias or precision.

- Using the criteria defined in EPA, 1993, matrix spike recoveries for an entire project are averaged, and all associated sample data are qualified on the basis of this average. Matrix spike-based qualification for this project, however, was done on a sample-bysample basis, using the criteria in subsection 3.4.3, Qualification of the Data.

- Two of four matrix spikes could not be evaluated due to high concentration of the analyte in the sample.

- No matrix spikes were provided for the split samples from the first event.

\subsection{Verification and Validation Issues}

\subsubsection{Analytical Narrative Review}

The EDDs and analytical narratives arrive from the laboratories and are logged in together. If the analytical narrative is missing, it is requested from the analytical laboratory. The narratives are reviewed and used as a reference throughout the data validation process. Discrepancies between the narratives and the analytical data must be resolved by the analytical laboratory. The analytical narratives contain summaries of the following problems encountered by the laboratory:

Data Summary Report for the 1997 Semiannual Tritium Survey for Fourmile Branch and the F- and H-Area Seeplines (WSRC-TR-97-00414) 
- QC samples that do not meet the criteria specified by the analytical method

- matrix interfèrence problems

- sample-specific adjustments to the method caused by high concentration of some analytes

- sample preservation and holding time problems

- instrument calibration problems

- contaminated blanks

- other laboratory QC issues

Additional information about the chain-of-custody data and analytical data is often found in the analytical narratives. Copies of the COC forms attached to the analytical narratives are used for data review.

\subsubsection{Laboratory Data Records Review}

On May 19-21, 1997, laboratory data records were reviewed at EP for selected analyses associated with this project. Tom Coffey of ExR conducted the review.

The purpose of the review is to investigate technical validation issues discussed in EPA, 1993, that are not adequately addressed by computer checking of the EDDs, by review of the analytical narratives, or by review of the COC forms. These technical issues include instrument calibration, analyte identification, and analyte quantitation. The issues are addressed by comparing the instrument printouts associated with particular analyses against validation checklists and the reviewer's professional judgment. The checklist for tritium contains 8 questions and was prepared from four sources: EPA, 1993; WHC (not dated), EP's standard operating procedures, and discussions with laboratory personnel.

Eight samples, approximately $10 \%$ of the total, were chosen for review. Samples identified as critical to the investigation were included in the review. Eight worksheets were completed, each representing one sample reviewed for one analyte for one analytical method, EPA 906.0, tritium by liquid scintillation spectrometry.

\section{Scoring}

The analysis date and time for one sample did not match the WSRC database.

\section{Qualification of Analyses}

No qualification was required. The analysis date and time are correct in the data provided with this report.

No LDRR was performed for the second sampling event.

\subsubsection{Qualification of the Data}

Each sample was evaluated on the following issues during validation:

- holding time

- sample preservation 
- instrument calibration

- analyte identification and quantitation

- method blanks

- laboratory control samples

- rinsates, field blanks, and field duplicates

- laboratory duplicates

- matrix spikes

- instrument readings

- additional information

\section{Holding Time}

\section{Criteria}

Each analysis was evaluated according to the 6-month holding time limit for radionuclides.

Action

When holding times were exceeded, the following qualifiers were applied:

Analysis Qualifier: $Q$

Result Qualifier: $\quad J$-for detects $\quad U J$-for nondetects

\section{Findings}

No environmental sample records from either sampling event were qualified based on holding times.

\section{Discussion}

Most methods specify limits on the time that can pass between sample collection and extraction or analysis. When holding times are exceeded, sample integrity may be compromised due to chemical and/or physical effects that can bias sample results either positively or negatively.

\section{Sample Preservation}

\section{Criteria}

Sample preservation requirements are determined by regulatory guidance, method specifications, and laboratory protocols.

\section{Findings}

No environmental sample records from either sampling event were qualified based on sample preservation. 


\section{Instrument Calibration}

\section{Criteria}

The calibration criteria specific to each method was used to evaluate instrument calibration during the LDRR.

Action

When calibration criteria were not met, the following qualifiers were assigned:

Analysis Qualifier: $L$

Result Qualifiers: $\quad J$ or $R$-detects $\quad U J$-for nondetects

\section{Findings}

No environmental sample records from either sampling event were qualified based on instrument calibration.

\section{Discussion}

Instrument calibration ensures that the instrument is capable of producing acceptable quantitative results. Initial calibration demonstrates that the instrument is capable of acceptable performance at the beginning of the analysis run. Continuing calibration verification documents that the initial calibration is still valid. After initial calibration, a continuing calibration standard and blank should be analyzed after every ten samples.

\section{Analyte Identification and Quantitation}

This issue was examined during the LDRR. The findings are presented in section 3.4.2, Laboratory Data Records Review.

\section{Trip Blanks}

\section{Criteria}

Trip blanks are used to determine the existence and magnitude of contamination from shipping activities.

\section{Action}

When an analyte is detected in a trip blank, an analysis qualifier is assigned to that analyte in the blank and to all samples that are shipped in the same cooler as the trip blank having positive results. If the analyte concentration in a sample is less than five times that in the blank (less than 10 times for the common laboratory contaminants acetone, dichloromethane [methylene chloride], and methyl ethyl ketone), assign a result qualifier to that analyte in the sample.

The following qualifiers may be assigned:

Analysis Qualifier: 8

Result Qualifier: $U$ 


\section{Findings}

There were no trip blanks associated with this project.

Discussion

Volatile organic contamination can be introduced into a trip blank in three ways: during blank preparation at the laboratory; during storage of the trip blank in the cooler; or by cross-contamination from other samples. The contamination can cause false positives in the trip blank and in the samples exposed to contamination.

\section{Method Blanks}

\section{Criteria}

Method blanks are used to determine the existence and magnitude of contamination from laboratory activities. Method blanks with analytical results greater than zero are considered to be contaminated. The CLP $5 \times / 10 \times$ rule is used for data qualification.

\section{Action}

When an analyte is detected in a method blank, an analysis qualifier is assigned to that analyte in the blank and to every sample of the preparation batch having positive results. If the analyte concentration in a sample is less than five times that in the blank (less than 10 times for common laboratory contaminants), assign a result qualifier to that analyte in the sample. A bias qualifier should be used only if the laboratory believes the sample is contaminated and has assigned the qualifier.

The following qualifiers may be assigned:

Analysis Qualifier: $\quad V$

Result Qualifier: $\quad U$

Bias Qualifier: $\quad H$

\section{Findings}

No environmental sample records from either sampling event were qualified based on method blank contamination.

\section{Discussion}

Laboratory contamination of samples during preparation and/or analysis is monitored through the method blank. Laboratory procedures may cause false positive results in the method blanks for common laboratory contaminants.

\section{Laboratory Control Samples}

\section{Criteria}

- Dioxins/furans: $40-120 \%$ recovery (EPA, 1986) 
- Inorganics: 80-120\% recovery except EPA6020 and EPA6020A, which have 70-130\% recovery

- Pesticides: Page D-61 PEST (EPA, 1991b)

- Radiologicals: 80-120\% (WHC, not dated)

- Semivolatiles: Table 7, page D-59 SV (EPA, 1991b)

- Volatiles: Table 7, page D-55 VOA (EPA, 1991b)

Action

When the percent recovery for an analyte in the LCS was outside the QC limits, that analyte in the LCS was qualified with an analysis qualifier. That analyte in each sample of the preparation batch was qualified. If an LCS was not included in the preparation batch, all spike compounds for the associated samples were qualified with an analysis and a results qualifier.

LCS recovery below lower QC limit:

Analysis Qualifier: $C$

Result Qualifiers: $J$-for detects $\quad U J$-for nondetects

LCS recovery above upper QC limit:

Analysis Qualifier: $C$

Result Qualifiers: $J$-for detects

Findings

For first quarter samples, none of the 65 environmental sample records was qualified. For third quarter samples, one of 43 environmental sample records was qualified because one of six LCSs was out of range. The preparation batch was used to correlate the samples with the spikes.

\section{Discussion}

LCS percent recoveries that exceed the upper QC limit could indicate a high bias for samples with positive results. Percent recoveries that are less than the lower QC limit could indicate a low bias for samples with positive results, and nondetect results should be considered questionable.

Rinsates, Field Blanks, and Field Duplicates

No qualification is performed based on rinsates, field blanks, and field duplicates.

\section{Laboratory Duplicates}

\section{Criteria}

- Inorganics: Page 10 (EPA, 1988a)

- Organics: No qualification is done on this basis. 
- Radiologicals: (WHC, not dated)

Findings

No environmental sample records from either sampling event were qualified based on RPDs.

\section{Matrix Spikes}

\section{Criteria}

- Dioxins: 40-120\% (EPA, 1986)

- Inorganics: Page 11 (EPA, 1988a)

- Pesticides: Page D-61 PEST (EPA, 1991b)

- Semivolatiles: Table 7, page D-59 SV (EPA, 1991b)

- Volatiles: Table 7, page D-55 VOA (EPA, 1991b)

\section{Action}

1. MS recovery limits do not apply when the spike concentration is less than $25 \%$ of the sample concentration. When this occurred, the MS record only was qualified as follows:

Analysis Qualifier: 5

Result Qualifier: $\quad R$

2. If the laboratory did not perform matrix spikes for nonradiological analyses, the following qualifier was used:

\section{Analysis Qualifier: I}

\section{Findings}

For first quarter, two of 65 environmental sample records were qualified with AQ.I because no matrix spike analyses were performed. For third quarter, 0 of 43 environmental sample records were qualified. The following table lists the frequency with which matrix spikes were rejected because the sample concentration was 4 times higher than the nominal concentration.

Table 3.7 Matrix Spikes With Sample Concentrations 4 Times Higher Than Nominal Concentration for Samples by EP

\begin{tabular}{|l|l|l|}
\hline Quarter & Analyte & Rejection Frequency \\
\hline $1 Q 97$ & Tritium & $1 / 2$ \\
\hline $3 Q 97$ & Tritium & $1 / 2$ \\
\hline
\end{tabular}

\section{Discussion}

When the matrix spike percent recovery for an analyte is high, the results for associated data may be biased positively. When the matrix spike percent recovery for an analyte is 
low, the results for associated data may be biased negatively, and the nondetected results should be considered questionable.

\section{Instrument Readings}

\section{Criteria}

For radiologicals, nondetected parameters reported from an instrument reading require a result qualifier.

\section{Action}

The result qualifier was as follows:

Result Qualifier: $\quad U I$-for nondetects

\section{Findings}

No environmental sample records from either sampling event were qualified.

\section{Discussion}

For radiological analyses, the laboratory instrumentation and data management software calculate the MDA, result, and accuracy. If the reported result was less than the MDA and/or the accuracy, a $U I$ result qualifier was assigned.

\subsection{Precision and Accuracy}

This section discusses the analytical data in terms of the precision and accuracy indicators of data quality. Precision is determined from the field and laboratory duplicate analyses and indicates the consistency of field and laboratory techniques. Accuracy is determined from the laboratory control samples, matrix spikes, and the results of the method, field, trip, and equipment blanks or rinsates and indicates the ability of the laboratory to generate correct results.

\subsubsection{Precision}

Precision is a measure of the repeatability of a measurement and is evaluated from the results of field and laboratory duplicate samples. Field duplicates measure the repeatability for the sampling and analytical techniques, and laboratory duplicates measure the ability of the laboratory to reproduce a result. Low precision can be caused by poor instrument performance, poor operator technique, inconsistent application of method protocols, laboratory environment, time between analyses, or by a difficult, heterogeneous sample matrix. Precision is especially important when the action limit approaches the quantitation limit. At least $5 \%$ of the samples are collected in duplicate. The laboratory performs duplicate analyses on at least $10 \%$ of the samples received.

Precision is expressed in terms of the relative percent difference as follows:

$$
R P D=\frac{|x-y|}{\left(\frac{x+y}{2}\right)} \times 100,
$$


where $x$ is the original sample result and $y$ is the duplicate sample result. When one result of a duplicate pair is below the MDL, the ssEQL is used for that result in the calculation. When both results are below the MDL, the RPD cannot be calculated.

The RPD should be less than $20 \%$ for water samples and less than $35 \%$ for soil samples when results are above the ssEQL. In the case where results are between the ssEQL and the MDL, the RPD should be less than $100 \%$ for water samples and less than $200 \%$ for soil samples.

The RPDs for the laboratory and field duplicates are listed in the following tables. The frequency out of range is the number of duplicates that had RPDs greater than the acceptance limit compared to the total number analyzed; the other columns provide the mean RPD, standard deviation, and the minimum and maximum RPDs.

Table 3.8 Relative Percent Differences of Field Duplicates for Water Samples by EP

\begin{tabular}{|c|c|c|c|c|c|c|}
\hline Quarter & Analyte & $\begin{array}{l}\text { Frequency } \\
\text { Out of } \\
\text { Range }\end{array}$ & $\begin{array}{l}\text { Mean } \\
\text { RPD }(\%)\end{array}$ & $\begin{array}{l}\text { Std. } \\
\text { Dev. }\end{array}$ & $\begin{array}{l}\text { Minimum } \\
\text { RPD (\%) }\end{array}$ & $\begin{array}{l}\text { Maximum } \\
\text { RPD (\%) }\end{array}$ \\
\hline \multicolumn{7}{|c|}{ Radionuclides } \\
\hline $1 Q 97$ & Tritium & $0 / 3$ & 6.64 & 0.567 & 6.23 & 7.29 \\
\hline 3Q97 & Tritium & $0 / 2$ & 3.82 & 3.62 & 1.26 & 6.38 \\
\hline
\end{tabular}

\subsubsection{Accuracy}

Accuracy is defined as the closeness of agreement between an observed value and an accepted reference value. Accuracy is especially important when the concentration of concern approaches the quantitation limit and/or the action limit. When the concentration is underestimated near the quantitation limit, the analyte may be present but reported as not detected. When the concentration is underestimated near the action limit, the analyte may be at a concentration that would require remediation, but the remediation would not be performed. When the concentration is overestimated near the quantitation limit, the analyte may not be present but reported as detected. When the concentration is overestimated near the action limit, the analyte may not be at a concentration that would require remediation, but the remediation would be performed. The sample types used to evaluate accuracy are performance evaluation studies (see Appendix B), LCS/BSs, surrogate spikes, and matrix spikes.

\section{Laboratory Control Samples}

LCSs monitor the performance of all steps in the analysis process, including sample preparation, and are used to identify problems with the analytical procedure. LCSs for inorganic analyses are DI water that is spiked with the target analyte, digested, and analyzed with the regular samples. LCSs for organic analyses are DI water that is spiked with selected target analytes, extracted, and analyzed with the regular samples. The LCS spiking solutions or solid LCSs are obtained from EPA or a third-party supplier or are prepared in the laboratory from chemicals from a different source than the calibration standards. The QC limits for radionuclide LCS are 80-120\%. 
The following table lists the statistical information for the percent recovery for LCSs by analyte. The frequency out of range is the number of LCSs that had percent recoveries outside the acceptance limits compared to the total number analyzed; the other columns provide the mean percent recovery, standard deviation, and the minimum and maximum percent recoveries.

The percent recovery is calculated as

$$
\% R=\frac{S R}{S A} \times 100
$$

where $\% \mathrm{R}=$ percent recovery

$\mathrm{SR}=\mathrm{LCS}$ sample result

$\mathrm{SA}=$ spike-added result

Table 3.9 Laboratory Control Sample Recoveries for Tritium in Water Samples

\begin{tabular}{|l|l|l|l|l|l|l|}
\hline Laboratory & Quarter & $\begin{array}{l}\text { Frequency } \\
\text { Out of } \\
\text { Range }\end{array}$ & $\begin{array}{l}\text { Mean } \\
\text { Recovery } \\
(\%)\end{array}$ & $\begin{array}{l}\text { Std. } \\
\text { Dev. }\end{array}$ & $\begin{array}{l}\text { Minimum } \\
\text { Recovery } \\
(\%)\end{array}$ & $\begin{array}{l}\text { Maximum } \\
\text { Recovery } \\
(\%)\end{array}$ \\
\hline Radionuclides & $1 \mathrm{Q} 97$ & $0 / 5$ & 98.3 & 4.76 & 93.2 & 103 \\
\hline EP & $3 Q 97$ & $1 / 6$ & 92.7 & 8.27 & 77.2 & 99.9 \\
\hline EP & $3 Q 97$ & $0 / 2$ & 94.9 & 0.636 & 94.4 & 95.3 \\
\hline EM &
\end{tabular}

\section{Matrix Spikes}

Matrix spikes are used to evaluate the effect of the sample matrix on the analytical procedure. Matrix spikes for at least $5 \%$ of the samples are prepared by adding a known quantity of the target analyte to the samples prior to sample preparation. All target analytes are spiked for the inorganic analyses. Selected target analytes are used in the spiking solution for the organic analyses. Results from the matrix spikes are used to evaluate the extent of matrix interference.

The QC limits for matrix spikes are the same as those for LCSs except for inorganics, which have limits of 75-125\%. Matrix spikes are rejected if the concentration of the analyte in the sample is more than four times the amount of the spike.

The following tables list the percent recovery for the matrix spikes. The frequency out of range is the number of matrix spikes that had percent recoveries outside the acceptance limits compared to the total number analyzed; the other columns provide the mean percent recovery, standard deviation, and the minimum and maximum percent recoveries. 
Table 3.10 Matrix Spike Recoveries for Tritium in Water Samples

\begin{tabular}{|l|l|l|l|l|l|l|}
\hline $\begin{array}{l}\text { Lab- } \\
\text { oratory }\end{array}$ & Quarter & $\begin{array}{l}\text { Frequency } \\
\text { Out of Range }\end{array}$ & $\begin{array}{l}\text { Mean } \\
\text { Recovery (\%) }\end{array}$ & $\begin{array}{l}\text { Std. } \\
\text { Dev. }\end{array}$ & $\begin{array}{l}\text { Minimum } \\
\text { Recovery (\%) }\end{array}$ & $\begin{array}{l}\text { Maximum } \\
\text { Recovery (\%) }\end{array}$ \\
\hline EP & $1 Q 97$ & $0 / 1$ & 91.7 & - & 91.7 & 91.7 \\
\hline EP & $3 Q 97$ & $0 / 3$ & 94.8 & 1.85 & 93.6 & 96.9 \\
\hline EM & $3 Q 97$ & $0 / 1$ & 97 & - & 96.96 & 96.96 \\
\hline
\end{tabular}

\subsubsection{Contamination in Quality Control Samples}

\section{Field Blanks}

Field blanks are used to identify possible sources of contamination from the processing and shipping of samples. Field blanks consist of DI water or dry quartz sand sealed in sample bottles prior to sampling, opened in the field during sampling, resealed, and shipped to the laboratory with the samples. Positive results from field blanks can result from contaminated sample bottles, contaminated DI water or quartz sand, vapors in the air during sampling, contamination during shipping or analysis, or analytical bias. The results from all samples in the sample delivery group are evaluated to determine the cause of the contamination and the corrective action to be taken.

No field blanks were associated with this project.

\section{Method Blanks}

Method blanks are used to determine the existence and magnitude of contamination resulting from the analytical process. Method blanks are analyte-free matrices (DI water for aqueous samples and sodium sulfate for solid samples) that are prepared in the same manner and at the same time as the samples. When method blanks have detectable concentrations of analytes, the laboratory must determine the cause and take corrective action to eliminate the contamination.

The following tables list the statistical information for the method blanks. The frequency detected column gives the number of method blanks analyzed for each analyte that had detectable concentrations compared to the total number analyzed. The other columns list the mean result, standard deviation, minimum and maximum results, and reporting unit. When the the analyte is not detected, the mean and minimum and maximum results are the ssEQLs for the method blanks.

Table 3.11 Frequency of Detection in Method Blanks for Water Samples by EP

\begin{tabular}{|l|l|l|l|l|l|l|}
\hline Analyte & Quarter & $\begin{array}{l}\text { Frequency } \\
\text { Detected }\end{array}$ & $\begin{array}{l}\text { Mean } \\
\text { Result }\end{array}$ & $\begin{array}{l}\text { Std. } \\
\text { Dev. }\end{array}$ & $\begin{array}{l}\text { Min/Max. } \\
\text { Result }\end{array}$ & Unit \\
\hline Tritium & $1 \mathrm{Q} 97$ & $0 / 5$ & 0.0012 & 0.095 & $-0.125 / 0.131$ & $\mathrm{pCi} / \mathrm{mL}$ \\
\hline Tritium & $3 \mathrm{Q} 97$ & $0 / 6$ & -0.0652 & 0.167 & $-0.267 / 0.216$ & $\mathrm{pCi} / \mathrm{mL}$ \\
\hline
\end{tabular}


Table 3.12 Frequency of Detection in Method Blanks for Water Samples by EM

\begin{tabular}{|l|l|l|l|l|l|l|}
\hline Analyte & Quarter & $\begin{array}{l}\text { Frequency } \\
\text { Detected }\end{array}$ & $\begin{array}{l}\text { Mean } \\
\text { Result }\end{array}$ & $\begin{array}{l}\text { Std. } \\
\text { Dev. }\end{array}$ & $\begin{array}{l}\text { Min.Max. } \\
\text { Result }\end{array}$ & Unit \\
\hline Tritium & $1 \mathrm{Q} 97$ & $0 / 2$ & 0 & 0.566 & $-0.4 / 0.4$ & $\mathrm{pCi} / \mathrm{mL}$ \\
\hline Tritium & $3 \mathrm{Q} 97$ & $0 / 2$ & -0.0005 & 0.216 & $-0.153 / 0.152$ & $\mathrm{pCi} / \mathrm{mL}$ \\
\hline
\end{tabular}

\section{Trip Blanks}

Trip blanks are used to detect contamination by volatile substances during shipping, primarily due to the breaking of the seal on the vial caused by depressurization during air transport. Trip blanks are analyzed for VOAs only. Trip blanks are prepared by the EPD/EMS laboratory for groundwater studies and by the analytical laboratory for other studies. If prepared by the analytical laboratory, trip blanks are shipped to EPD/EMS with the sample containers. The blanks are prepared by adding preservative to a $40-\mathrm{mL}$ vial, filling it completely with DI water (no air bubbles), and sealing the top with a Teflonlined septum cap. If a trip blank is found to be contaminated, the results from all samples shipped in the same cooler are evaluated to determine the extent of the contamination and the corrective action to be taken.

No trip blanks were associated with this project.

\section{Rinsates}

Rinsates are used to determine if sampling equipment that has been cleaned in the field is contaminated. Prior to sampling, DI water is poured over or pumped through portions of the sampling equipment that come in contact with the sample. If the rinsate is contaminated, the field cleaning procedure must be evaluated to determine the cause of the contamination. Results for all samples collected with equipment cleaned in the field must be evaluated to determine if the contamination is isolated or generalized.

No rinsates were associated with this project.

\subsubsection{Comparability}

The comparability of the data from the laboratories is based on the results of the split samples. For at least $10 \%$ of the sample locations, a split sample is collected and sent to the designated QC laboratory. The following table lists the RPDs, sample IDs, results that are greater than the quantitation limit for each analyte, and reporting units.

Table 3.13 Split Sample Results for Water Samples

\begin{tabular}{|l|l|l|l|l|l|l|}
\hline Quarter & RPD & EP Sample ID & EP Result & EM Sample ID & EM Result & Unit \\
\hline $1 \mathrm{Q} 97$ & 21.4 & 110522 & 202 & 110523 & 163 & $\mathrm{pCi} / \mathrm{mL}$ \\
\hline $1 \mathrm{Q} 97$ & 13.8 & 110558 & 101 & 110559 & 116 & $\mathrm{pCi} / \mathrm{mL}$ \\
\hline $3 \mathrm{Q} 97$ & 0.244 & 111700 & 41 & 111701 & 40.9 & $\mathrm{pCi} / \mathrm{mL}$ \\
\hline $3 \mathrm{Q} 97$ & 4.29 & 111721 & 114 & 111722 & 119 & $\mathrm{pCi} / \mathrm{mL}$ \\
\hline $3 \mathrm{Q} 97$ & 1.03 & 111735 & 1940 & 111763 & 1960 & $\mathrm{pCi} / \mathrm{mL}$ \\
\hline
\end{tabular}


This page was left blank intentionally. 
DOE (U.S. Department of Energy), 1992. Environmental Measurements Laboratory Procedures Manual, HASL-300, 27th edition. Environmental Measurements Laboratory, New York, NY.

EPA (U.S. Environmental Protection Agency), 1983. Methods for Chemical Analysis of Water and Wastes, EPA-600/4-79-020. Environmental Monitoring and Support Laboratory, Cincinnati, $\mathrm{OH}$.

EPA (U.S. Environmental Protection Agency), 1986. Test Methods for Evaluating Solid Waste (SW-846), Volume I, including updates. Office of Solid Waste, Washington, DC.

EPA (U.S. Environmental Protection Agency), 1988a. Laboratory Data Validation Functional Guidelines for Evaluating Inorganics Analyses. Hazardous Site Evaluation Division, Washington, DC.

EPA (U.S. Environmental Protection Agency), 1988b. Laboratory Data Validation Functional Guidelines for Evaluating Organics Analyses. Hazardous Site Evaluation Division, Washington, DC.

EPA (U.S. Environmental Protection Agency), 1990. Guidance for Data Usability in Risk Assessment, EPA/540/G-90/008. Office of Emergency and Remedial Response, Washington, DC.

EPA (U.S. Environmental Protection Agency), 1991a. U.S. EPA Contract Laboratory Program, Statement of Work for Organics Analysis, Multi-Media, MultiConcentration, OLM01.0. Washington, DC.

EPA (U.S. Environmental Protection Agency), 1991b. U.S. EPA Contract Laboratory Program, Statement of Work for Inorganics Analysis, Multi-Media, MultiConcentration, ILM03.0. Washington, DC.

EPA (U.S. Environmental Protection Agency), 1991c. Test Method: The Determination of Inorganic Anions in Water by Ion Chromatography-Method 300.0.

Environmental Monitoring and Support Laboratory, Cincinnati, $\mathrm{OH}$.

EPA (U.S. Environmental Protection Agency), 1993. Data Quality Objectives Process for Superfund, EPA 540/R-93/071. Washington, DC.

EPA (U.S. Environmental Protection Agency), 1994a. Guidelines Establishing Test Procedures for the Analysis of Pollutants, Code of Federal Regulations, Title 40, Part 136. Washington, DC.

EPA (U.S. Environmental Protection Agency), 1994b. Identification and Listing of Hazardous Waste, Code of Federal Regulations, Title 40, Part 261. Washington, DC.

WHC (Westinghouse Hanford Company), not dated. Data Validation Procedures for Radiochemical Analyses, WHC-SP-EN-SPP-001, rev. 1. Richland, WA. 


\section{Appendix A: Analytical Methods and Quantitation Limits}

In the following table of radiological analytical methods and quantitation limits, the mean minimum detectable activity (MDA) column reports the minimum activity for each radionuclide/method combination that was reported by each laboratory for this project. Only environmental sample records were used to develop the mean for the primary laboratory (GE, using method EPA906.0); field and laboratory QC samples were not used. Split sample records (only) were used to develop the mean for the QC laboratory (EM, using method ).

Table A.1 Analytical Methods and Mean Quantitation Limits

\begin{tabular}{|l|l|l|l|}
\hline Analyte & Method & Unit & Mean MDA \\
\hline Tritium & EPA906.0 & $\mathrm{pCi} / \mathrm{mL}$ & 5.78 \\
\hline Tritium & WSRC3Q161410 & $\mathrm{pCi} / \mathrm{mL}$ & 1.50 \\
\hline
\end{tabular}




\section{Appendix B: Laboratory Performance Evaluation Results}

This appendix contains recent performance evaluation results for the laboratories that report data for soils and groundwater samples. Not all laboratories report data for each project.

\section{B.1 EPA Performance Evaluation Study Results}

EPA conducts the water pollution (WP) and water supply (WS) performance evaluation studies biannually to certify laboratories for specific analyses. EPA's Environmental Monitoring Systems Laboratory (EMSL) of Cincinnati, OH, distributes water samples spiked with known concentrations of constituents found in polluted waters and potable water and submits them to laboratories seeking certification to analyze wastewater and potable water. EMSL evaluates the results, using limits statistically based on the performance of approximately 100 top-rated laboratories that analyze each constituent by the same procedure as the laboratory being evaluated.

All laboratories reported results for WP036, and EMAX, QST, and Recra reported results for WP037.

For study WP036, the results from EMAX were outside the acceptance limits for chloride, potassium, and sodium. The results for dibromochloro-methane and nonfilterable residue were acceptable but near the acceptance limits; EMAX was instructed to check for error. The results from GE were outside the acceptance limits for fluoride, magnesium, potassium, and total phosphorus. In addition, the results for benzene and methylene chloride were acceptable but near the acceptance limits; GE was instructed to check for error. The results from QST were outside the acceptance limits for chloroform and methylene chloride. In addition, the results for 5-day biochemical oxygen demand, bromodichloromethane, 1,3-dichlorobenzene, and tetrachloroethylene were acceptable but near the acceptance limits; QST was instructed to check for error. The results from Recra for all analytes were within acceptance limits.

For study WP037, the results for EMAX were outside the acceptance limits for fluoride, total phosphorus, and total phenolics. The results for QST were outside the acceptance limits for total beryllium, and total phenolics. The result for carbonaceous biochemical oxygen demand was acceptable but near the acceptance limits; QST was instructed to check for error. The results for Recra were outside the acceptance limits for calcium, total organic carbon, and nonfilterable residue. The results for magnesium and sodium were acceptable but near the acceptance limits; Recra was instructed to check for error.

EMAX and QST reported results for WS037, and EMAX, GE, and QST reported results for WS038.

For WS037, the results for EMAX were outside the acceptance limits for dieldrin, endrin, nitrite, orthophosphate, propachlor, total organic carbon, toxaphene, and trifluralin. The results for QST were outside the acceptance limits for 2,4-D, hardness, nitrate, pentachlorophenol, total organic carbon, and 2,4,5-TP (Silvex). 
For WS038, the results for EMAX were outside the acceptance limits for 2,4-D, propachlor, tetrachloroethylene, and total organic carbon. The results for $\mathrm{GE}$ were outside the acceptance limits for dicamba and zinc. The results for QST were outside the acceptance limits for 2,4-D, cis-1,2-dichloroethylene, and orthophosphate.

\section{B.2 EMS Quality Control Standards Results}

During second quarter 1997, EPD/EMS conducted quality assessments of the laboratories. Each laboratory received a set of certified environmental quality control standards from Environmental Resource Associates (ERA) of Arvada, CO (lot numbers 573, 3218, 3418, 8915, and 9973). Each laboratory's results were compared with the ERA-certified values and performance acceptance limits (PALs). The PALs are listed as guidelines for acceptable analytical results given the limitations of the EPA methods used to determine these parameters. The PALs closely approximate the $95 \%$ confidence interval.

Of the 100 analyses reported by GE, 96 (or 96\%), were within the PALs. Of 99 analyses reported by Recra, 94 (or $95 \%$ ), were within the PALs. Of the 100 analyses reported by QST, 97 (or 97\%) were within the PALs. Of the 98 analyses reported by EMAX, 91 (or 93\%) were within the PALs.

\section{B.3 Mixed Analyte Performance Evaluation Program}

The Department of Energy mixed analyte performance evaluation program provides proficiency samples containing metals, pesticides, and radionuclides. The results from the June 1996 MAPEP-96-S3 study were reported in December 1996. GE and Recra reported only chemical analyses, and EP and TNU reported only radionuclide analyes.

For GE, copper was not acceptable and nickel was reported at $23.4 \mathrm{mg} / \mathrm{kg}$ although it was not included in the original sample. Five of the eight pesticides had a negative bias and were not acceptable; $4,4^{\circ}-\mathrm{DDE}$ and methoxychlor were not reported. For Recra, all the metals were within the acceptance limits. Four of the eight pesticides were not acceptable, three were acceptable, and methoxychlor was not reported.

For Environmental Physics, Inc. (EP), all eight radionuclides were acceptable, but plutonium-238 was close to the upper acceptance limit and given a warning flag. For Thermo NUtech (TNU), seven of eight radionuclides were within the acceptance limits; however the result for strontium-90 was not acceptable. The results for EP and TNU are reported in table B.1.

The results for MAPEP-96-W4 were reported in April 1997. For QST, the results for 4methylphenol and phenol were outside the acceptance limits. 
Table B.1 Mixed Analyte Performance Evaluation Program Results for MAPEP. 96-S3 for EP and TNU

\begin{tabular}{|c|c|c|c|c|}
\hline Analyte & EP Result & TNU Result & $\begin{array}{l}\text { Reference } \\
\text { Value }\end{array}$ & $\begin{array}{l}\text { Acceptance } \\
\text { Limits }\end{array}$ \\
\hline \multicolumn{5}{|c|}{ Radionuclides (Bq/kg) } \\
\hline Americium-241 & 29.0 & 28.7 & 28.7 & $20.09-37.31$ \\
\hline Cesium-137 & 1770 & 1359 & 1531 & $1071.7-1990.3$ \\
\hline Cobalt-60 & 931 & 727 & 812 & $568.4-1055.6$ \\
\hline Plutonium-238 & $20.5^{\mathrm{a}}$ & 17.3 & 15.9 & $11.13-20.67$ \\
\hline Plutonium-239/240 & 22.6 & 18.9 & 19.7 & $13.79-25.61$ \\
\hline Strontium-90 & 540 & $347^{\mathrm{b}}$ & 536.0 & $375.2-696.8$ \\
\hline Uranium-233/234 & 56.6 & 59.7 & 63.9 & $44.73-83.07$ \\
\hline Uranium-238 & 52.9 & 59.7 & 64.0 & $44.80-83.20$ \\
\hline
\end{tabular}

\section{B.4 EPA Radiological Performance Evaluation Studies}

EP and QR participated in the EPA radiological performance evaluation studies administered by the Characterization Research Division-Las Vegas. The studies included in this order are the following:

- Tritium in Water, August 9, 1996

- Blind-A, October 15, 1996

- Blind B, October 15, 1996

- Gamma in Water, November 8, 1996

- Strontium in Water, January 17, 1997

- Gross Alpha-Beta in Water, January 31, 1997

- Iodine in Water, February 7, 1997

- Uranium-Radium in Water, February 14, 1997

For tritium in water (8/9/96), the results were $9,613 \mathrm{pCi} / \mathrm{L}$ for $\mathrm{EP}$ and $10,707 \mathrm{pCi} / \mathrm{L}$ for $\mathrm{QR}$. The EPA reference value was $10,879 \mathrm{pCi} / \mathrm{L}$ and the acceptance limits were 8,991-12,767 $\mathrm{pCi} / \mathrm{L}$.

For iodine in water (2/7/97), both EP and QR reported results of $88.00 \mathrm{pCi} / \mathrm{L}$. The EPA reference value was $86.0 \mathrm{pCj} / \mathrm{L}$ and the acceptance limits were $70.4-101.6 \mathrm{pCi} / \mathrm{L}$.

In the following tables, all results are reported in $\mathrm{pCi} / \mathrm{L}$.

a In cases where a warning was given, the reported values appear in bold italic.

b Reported values that were outside the acceptance limits appear in bold. 
Table B.2 Blind-A Results for EP and QR (10/15/96)

\begin{tabular}{|l|l|l|l|l|}
\hline Analyte & EP Result & QR Result & $\begin{array}{l}\text { Reference } \\
\text { Value }\end{array}$ & $\begin{array}{l}\text { Acceptance } \\
\text { Limits }\end{array}$ \\
\hline Gross Alpha & 65.27 & 48.87 & 59.1 & $33.4-84.8$ \\
\hline Radium-226 & 9.40 & 9.60 & 9.9 & $7.3-12.5$ \\
\hline Radium-228 & 4.67 & 4.57 & 5.1 & $2.8-7.4$ \\
\hline Uranium (natural) & 37.33 & 40.10 & 40.9 & $33.8-48.0$ \\
\hline
\end{tabular}

Table B.3 Blind-B Results for EP and QR (10/15/96)

\begin{tabular}{|l|l|l|l|l|}
\hline Analyte & EP Result & QR Result & $\begin{array}{l}\text { Reference } \\
\text { Value }\end{array}$ & $\begin{array}{l}\text { Acceptance } \\
\text { Limits }\end{array}$ \\
\hline Cesium-134 & 18.00 & 18.00 & 20.0 & $11.3-28.7$ \\
\hline Cesium-137 & 31.33 & 30.67 & 30.0 & $21.3-38.7$ \\
\hline Cobalt-60 & 15.33 & 15.33 & 15.0 & $6.3-23.7$ \\
\hline Gross Beta & $\mathbf{4 3 . 4 3}$ & 119.67 & 111.8 & $82.7-140.9$ \\
\hline Strontium-89 & 11.67 & 16.67 & 10.0 & $1.3-18.7$ \\
\hline Strontium-90 & 24.67 & 21.33 & 25.0 & $16.3-33.7$ \\
\hline
\end{tabular}

Table B.4 Gamma in Water Results for EP and QR (11/8/96)

\begin{tabular}{|l|l|l|l|l|}
\hline Analyte & EP Result & QR Result & $\begin{array}{l}\text { Reference } \\
\text { Value }\end{array}$ & $\begin{array}{l}\text { Acceptance } \\
\text { Limits }\end{array}$ \\
\hline Cobalt-60 & 45.67 & 43.33 & 44.0 & $35.3-52.7$ \\
\hline Zinc-65 & 39.33 & 36.67 & 35.0 & $26.3-43.7$ \\
\hline Cesium-134 & 10.67 & 9.33 & 11.0 & $2.3-19.7$ \\
\hline Cesium-137 & 22.67 & 20.33 & 19.0 & $10.3-27.7$ \\
\hline Barium-133 & 64.67 & 61.00 & 64.0 & $53.6-74.4$ \\
\hline
\end{tabular}

Table B.5 Strontium in Water Results for EP and QR (1/17/97)

\begin{tabular}{|l|l|l|l|l|}
\hline Analyte & EP Result & QR Result & $\begin{array}{l}\text { Reference } \\
\text { Value }\end{array}$ & $\begin{array}{l}\text { Acceptance } \\
\text { Limits }\end{array}$ \\
\hline Strontium-89 & 8.67 & 11.00 & 12.0 & $3.3-20.7$ \\
\hline Strontium-90 & 26.33 & 24.33 & 25.0 & $16.3-33.7$ \\
\hline
\end{tabular}

c Reported values that were out of range appear in bold.

Data Summary Report for the 1997 Semiannual Tritium Survey for Fourmile Branch and the F- and H-Area Seeplines (WSRC-TR-97-00414) 
Table B.6 Gross Alpha-Beta in Water Results for EP and QR (1/31/97)

\begin{tabular}{|l|l|l|l|l|}
\hline Analyte & EP Result & QR Result & $\begin{array}{l}\text { Reference } \\
\text { Value }\end{array}$ & $\begin{array}{l}\text { Acceptance } \\
\text { Limits }\end{array}$ \\
\hline Gross alpha & 4.83 & 4.60 & 5.2 & $0.0-13.9$ \\
\hline Gross beta & 14.23 & 17.40 & 14.7 & $6.0-23.4$ \\
\hline
\end{tabular}

Table B.7 Uranium-Radium in Water Results for EP and QR (2/14/97)

\begin{tabular}{|l|l|l|l|l|}
\hline Analyte & EP Result & QR Result & $\begin{array}{l}\text { Reference } \\
\text { Value }\end{array}$ & $\begin{array}{l}\text { Acceptance } \\
\text { Limits }\end{array}$ \\
\hline Radium-226 & $5: 17$ & 5.90 & 5.9 & $4.3-7.5$ \\
\hline Radium-228 & 7.30 & 8.33 & 8.2 & $4.6-11.8$ \\
\hline Uranium (natural) & 32.07 & 27.8 & 27.0 & $21.8-32.2$ \\
\hline
\end{tabular}




\section{Appendix C: Formats of the Data Files}

The formats presented in this appendix have been established by WSRC-EPD/EMS. When entering data in any of the formats, the following conventions are to be used:

- Alpha and alphanumeric entries must be left justified in the records.

- Numeric entries must be right justified in the records.

- There will be no leading zeros except in dates and times.

Table C.1 describes the sample data format, SAM93, which is used for coding and transmitting sampling data records.

Table C.1 Sample Data Format SAM93

\begin{tabular}{|c|c|c|c|}
\hline Name & Columns & Type & Description \\
\hline Record format & $1-8$ & Alphanumeric & SAM93 (the format of the data record) \\
\hline $\begin{array}{l}\text { Sample } \\
\text { identification } \\
\text { number }\end{array}$ & $9-14$ & Integer & $\begin{array}{l}\text { Number of the sample printed on the page } \\
\text { of the sample logbook }\end{array}$ \\
\hline $\begin{array}{l}\text { Sample collection } \\
\text { date }\end{array}$ & $15-20$ & Numeric & $\begin{array}{l}\text { Sample collection date recorded using the } \\
\text { MMDDYY format }\end{array}$ \\
\hline $\begin{array}{l}\text { Sample collection } \\
\text { time }\end{array}$ & $21-24$ & Integer & $\begin{array}{l}\text { Sample collection time recorded as military } \\
\text { time }\end{array}$ \\
\hline Sample type & 25 & Numeric & $\begin{array}{l}\text { Sample type coded as } \\
1=\text { normal } \\
2=\text { trip blank } \\
3=\text { field blank } \\
4=\text { split } \\
5=\text { rinsate } \\
6=\text { duplicate } \\
7=\text { other }\end{array}$ \\
\hline Sample matrix & 26 & Numeric & $\begin{array}{l}\text { Sample matrix coded as } \\
1=\text { soil } \\
2=\text { rock } \\
3=\text { sludge } \\
4=\text { water } \\
5=\text { sediment } \\
6=\text { other }\end{array}$ \\
\hline Delay check & 27 & Alpha & $\begin{array}{l}\text { Enter a } Y \text { if there was an unusual delay in } \\
\text { bottling samples }\end{array}$ \\
\hline Sampler's initials & $28-30$ & Alpha & Sampler's initials \\
\hline Associated sample & $31-36$ & Integer & $\begin{array}{l}\text { Sample identification of associated sample } \\
\text { if this sample is a duplicate, split, rinsate, } \\
\text { etc. }\end{array}$ \\
\hline
\end{tabular}


Table C.1 Sample Data Format SAM93 (cont.)

\begin{tabular}{|c|c|c|c|}
\hline Name & Columns & Type & Description \\
\hline $\begin{array}{l}\text { Planned sample } \\
\text { name }\end{array}$ & $37-46$ & Alphanumeric & $\begin{array}{l}\text { Identification of the sample as it appears in } \\
\text { the site work plan }\end{array}$ \\
\hline Sample name & $47-56$ & Alphanumeric & $\begin{array}{l}\text { Identification of the actual sample (includes } \\
\text { any modification made in the field) }\end{array}$ \\
\hline $\begin{array}{l}\text { Planned top of } \\
\text { interval }\end{array}$ & $57-62$ & Numeric & $\begin{array}{l}\text { Depth from the ground to the top of the } \\
\text { planned sampling interval to the nearest } \\
0.01 \mathrm{ft}\end{array}$ \\
\hline Top of interval & $63-68$ & Numeric & $\begin{array}{l}\text { Depth from the ground to the top of the } \\
\text { actual sampling interval to the nearest } \\
0.01 \mathrm{ft} \text {. }\end{array}$ \\
\hline $\begin{array}{l}\text { Planned bottom of } \\
\text { interval }\end{array}$ & $69-74$ & Numeric & $\begin{array}{l}\text { Depth from the ground to the bottom of the } \\
\text { planned sampling interval to the nearest } \\
0.01 \mathrm{ft}\end{array}$ \\
\hline Bottom of interval & $75-80$ & Numeric & $\begin{array}{l}\text { Depth from the ground to the bottom of the } \\
\text { actual sampling interval to the nearest } \\
0.01 \mathrm{ft}\end{array}$ \\
\hline Soil moisture ${ }^{a}$ & 81 & Numeric & $\begin{array}{l}\text { Soil moisture coded as } \\
1=\text { dry } \\
2=\text { damp } \\
3=\text { wet } \\
4=\text { sludge } \\
5=\text { liquid }\end{array}$ \\
\hline Munsell color ${ }^{\mathrm{a}}$ & 82-91 & Alphanumeric & Munsell color \\
\hline Soil classification ${ }^{\mathrm{a}}$ & $92-93$ & Alphanumeric & Unified Soil Classification \\
\hline Number of bottles & $94-96$ & Integer & $\begin{array}{l}\text { Number of bottle label numbers used } \\
\text { during collection }\end{array}$ \\
\hline $\begin{array}{l}\text { Insufficient } \\
\text { recovery check }\end{array}$ & 97 & Alpha & $\begin{array}{l}\text { Enter an } R \text { if insufficient material was } \\
\text { recovered to perform all analyses } \\
\end{array}$ \\
\hline $\begin{array}{l}\text { Improper } \\
\text { procedure check }\end{array}$ & 98 & Alpha & $\begin{array}{l}\text { Enter a } P \text { if an improper sampling } \\
\text { procedure was followed }\end{array}$ \\
\hline
\end{tabular}

a No datum is reported for this field. 
Table C.2 is a description of the sample bottle data format, SAM93A, which is used for coding and transmitting sample bottle data records.

Table C.2 Sample Bottle Data Format SAM93A

\begin{tabular}{|l|l|l|l|}
\hline Name & Columns & Type & Description \\
\hline Record format & $1-8$ & Alphanumeric & SAM93A (the format of the data record) \\
\hline $\begin{array}{l}\text { Sample identification } \\
\text { number }\end{array}$ & $9-14$ & Integer & $\begin{array}{l}\text { Number of the sample printed on the } \\
\text { page of the sample logbook }\end{array}$ \\
\hline Bottle label number & $15-23$ & Integer & $\begin{array}{l}\text { Number of the bottle label attached to } \\
\text { the bottle }\end{array}$ \\
\hline
\end{tabular}

Table C.3 is a description of the survey station data format, STA93, which is used for coding and transmitting station data records.

Table C.3 Survey Station Data Format STA93

\begin{tabular}{|l|l|l|l|}
\hline Name & Columns & Type & Description \\
\hline Record format & $1-8$ & Alphanumeric & STA93 (the format of the data record) \\
\hline Station & $9-18$ & Alphanumeric & $\begin{array}{l}\text { Identification of the station (the facility } \\
\text { identification and sampling point) }\end{array}$ \\
\hline SRS north coordinate & $20-27$ & Numeric & $\begin{array}{l}\text { SRS grid north coordinate of the station } \\
\text { reported in feet }\end{array}$ \\
\hline SRS east coordinate & $29-36$ & Numeric & $\begin{array}{l}\text { SRS grid east coordinate of the station } \\
\text { reported in feet }\end{array}$ \\
\hline Ground elevation & $43-48$ & Numeric & $\begin{array}{l}\text { Ground elevation reported in feet above } \\
\text { median sea level }\end{array}$ \\
\hline
\end{tabular}


Table C.4 is a description of the chain-of-custody data format, COC93, which is used for coding and transmitting chain-of-custody data records.

\section{Table C.4 Chain-of-Custody Data Format COC93}

\begin{tabular}{|l|l|l|l|}
\hline Name & Columns & Type & Description \\
\hline Record format & $1-8$ & Alphanumeric & COC93 (the format of the data record) \\
\hline $\begin{array}{l}\text { Sample identification } \\
\text { number }\end{array}$ & $9-18$ & Integer & $\begin{array}{l}\text { Number of the sample printed on the page } \\
\text { of the sample logbook }\end{array}$ \\
\hline $\begin{array}{l}\text { Laboratory sample } \\
\text { identification }\end{array}$ & $19-33$ & Alphanumeric & $\begin{array}{l}\text { Identifier used for the sample by the } \\
\text { analytical laboratory }\end{array}$ \\
\hline Sample collection date & $34-39$ & Numeric & $\begin{array}{l}\text { Sample collection date recorded using the } \\
\text { MMDDYY format }\end{array}$ \\
\hline Shipping date & $40-45$ & Numeric & $\begin{array}{l}\text { Sample shipping date recorded using the } \\
\text { MMDDYY format }\end{array}$ \\
\hline Cooler identification & $46-53$ & Alphanumeric & $\begin{array}{l}\text { Number assigned to the cooler in which the } \\
\text { samples are shipped to the analytical } \\
\text { laboratory }\end{array}$ \\
\hline $\begin{array}{l}\text { Sample temperature } \\
\text { upon receipt }\end{array}$ & $54-57$ & Numeric & $\begin{array}{l}\text { Temperature of the samples upon receipt } \\
\text { at the analytical laboratory in }{ }^{\circ} \mathrm{C}\end{array}$ \\
\hline
\end{tabular}

Table C.5 is a description of the analytical data format, AN95, which is used for coding and transmitting analytical data records.

Table C.5 Analytical Data Format AN95

\begin{tabular}{|l|l|l|l|}
\hline Name & Columns & Type & Description \\
\hline WSRC identifierb & $1-12$ & Alphanumeric & WSRC identifier for the sample \\
\hline COC number & $13-17$ & Alphanumeric & $\begin{array}{l}\text { Identifier of the sample's chain-of-custody } \\
\text { form (Required field for groundwater } \\
\text { samples; not used for soil samples) }\end{array}$ \\
\hline Sample collection date & $18-23$ & Numeric & $\begin{array}{l}\text { Date the sample was collected. Enter the } \\
\text { preparation date for laboratory blanks } \\
\text { and QC samples; enter the date of } \\
\text { completion of TCLP sample generation for } \\
\text { TCLP samples }\end{array}$ \\
\hline Sample collection time & $24-27$ & Numeric & \begin{tabular}{l} 
Time of sample collection or generation \\
\hline Lab receipt date
\end{tabular} \\
\hline $28-33$ & Numeric & $\begin{array}{l}\text { Date the sample was received by the } \\
\text { laboratory; blank for laboratory blanks } \\
\text { and QC samples }\end{array}$ \\
\hline Extraction date & $34-39$ & Numeric & $\begin{array}{l}\text { Date the sample was extracted; blank } \\
\text { unless the holding time is dependent upon } \\
\text { the extraction time }\end{array}$ \\
\hline
\end{tabular}

b This field must have an entry for every record. 
Table C.5 Analytical Data Format AN95 (cont.)

\begin{tabular}{|c|c|c|c|}
\hline Name & Columns & Type & Description \\
\hline Extraction time & $40-43$ & Numeric & $\begin{array}{l}\text { Time the sample extraction was started; } \\
\text { blank unless the holding time is } \\
\text { dependent upon the extraction time }\end{array}$ \\
\hline $\begin{array}{l}\text { Extraction/digestion } \\
\text { method }\end{array}$ & $44-56$ & Alphanumeric & $\begin{array}{l}\text { Coded identifier for the method used to } \\
\text { perform the extraction or digestion (e.g., } \\
\text { EPA\#\#\#.\#) }\end{array}$ \\
\hline Analysis date & $57-62$ & Numeric & $\begin{array}{l}\text { Date the analyte concentration was } \\
\text { determined }\end{array}$ \\
\hline Analysis time ${ }^{a}$ & $63-66$ & Numeric & $\begin{array}{l}\text { Time the analyte concentration was } \\
\text { determined }\end{array}$ \\
\hline Analytical methoda & $67-79$ & Alphanumeric & $\begin{array}{l}\text { Coded identifier for the method used to } \\
\text { perform the analysis (e.g., EPA\#\#\#.\#) }\end{array}$ \\
\hline Preparation batch & $80-87$ & Alphanumeric & $\begin{array}{l}\text { Identification of the sample preparation } \\
\text { batch }\end{array}$ \\
\hline Laboratory ${ }^{\mathrm{a}}$ & $88-89$ & Alphanumeric & $\begin{array}{l}\text { Code assigned by EPD/EMS to identify } \\
\text { the laboratory performing the analysis }\end{array}$ \\
\hline $\begin{array}{l}\text { Laboratory sample } \\
\text { identification }\end{array}$ & $90-104$ & Alphanumeric & $\begin{array}{l}\text { Identifier used for the sample by the } \\
\text { analytical laboratory }\end{array}$ \\
\hline Laboratory replicate & $105-107$ & Alphanumeric & $\begin{array}{l}\text { Indicates that the sample is a non-blind } \\
\text { replicate analysis (see table C.8) }\end{array}$ \\
\hline Analytea & $108-117$ & Alphanumeric & EPD/EMS identifier for the analyte \\
\hline Quantitation limit & $118-125$ & Numeric & $\begin{array}{l}\text { GE and WA report the ssEQL for non- } \\
\text { radiochemistry analyses; all labs report } \\
\text { the MDA for radiochemistry analyses }\end{array}$ \\
\hline Result qualifier & $126-128$ & Alphanumeric & $\begin{array}{l}\text { Coded field used to qualify the analytical } \\
\text { result (see table D.1) }\end{array}$ \\
\hline Analysis qualifier & $129-131$ & Alphanumeric & $\begin{array}{l}\text { Coded field used to qualify the analytical } \\
\text { result (see table D.2) }\end{array}$ \\
\hline Bias of analysis & 132 & Alphanumeric & $\begin{array}{l}\text { Coded field for specifying the expected } \\
\text { bias (see table D.3) }\end{array}$ \\
\hline Analytical result & $133-142$ & Numeric & $\begin{array}{l}\text { Concentration of the analyte. For non- } \\
\text { detects, the ssEQL is reported. Results } \\
\text { are reported on a dry weight basis for all } \\
\text { analyses reported in per mass units }\end{array}$ \\
\hline Result unita & $143-146$ & Alpha & $\begin{array}{l}\text { Unit in which the analytical result is } \\
\text { expressed }\end{array}$ \\
\hline Accuracy & $147-154$ & Numeric & $\begin{array}{l}\text { Statistically determined value, } 95 \% \\
\text { confidence level, representing a plus or } \\
\text { minus value for the result and reported in } \\
\text { the same units as the analytical result. } \\
\text { Required for all radiochemical analyses } \\
\text { above the detection limit, but not } \\
\text { generally reported for non-radiochemical } \\
\text { analyses. Do not report more figures than } \\
\text { are significant }\end{array}$ \\
\hline
\end{tabular}


Table C.5 Analytical Data Format AN95 (cont.)

\begin{tabular}{|c|c|c|c|}
\hline Name & Columns & Type & Description \\
\hline Residual weight & $155-160$ & Numeric & $\begin{array}{l}\text { Weight of material in milligrams on the } \\
\text { planchet after evaporation; used for } \\
\text { radionuclide determinations }\end{array}$ \\
\hline Nominal concentration ${ }^{a}$ & $161-168$ & Numeric & $\begin{array}{l}\text { Concentration of analyte added to the } \\
\text { sample prior to analysis; reported in the } \\
\text { same units as the analytical result. Zero } \\
\text { must be entered if the sample was not } \\
\text { spiked }\end{array}$ \\
\hline Percent recovery & $169-174$ & Numeric & $\begin{array}{l}\text { Recovery of the spiked constituent } \\
\text { reported as a percentage }\end{array}$ \\
\hline Number of dilutions ${ }^{a}$ & 175 & Numeric & $\begin{array}{l}\text { Number of steps required to reach the } \\
\text { final dilution factor. Zero must be entered } \\
\text { if the sample was not diluted }\end{array}$ \\
\hline Dilution factor ${ }^{\mathrm{a}}$ & $176-181$ & Numeric & $\begin{array}{l}\text { Dilution used in the analysis; a value of } \\
\text { one indicates the sample was not diluted }\end{array}$ \\
\hline Instrumenta & $182-189$ & Alphanumeric & $\begin{array}{l}\text { Coded identifier for the instrument used } \\
\text { to perform the analysis; each laboratory } \\
\text { develops its own codes and provides them } \\
\text { to EPD/EMS }\end{array}$ \\
\hline Instrument batch ${ }^{a}$ & $190-197$ & Alphanumeric & $\begin{array}{l}\text { Number assigned by the analytical } \\
\text { laboratory to the analysis batch (group of } \\
\text { samples analyzed together in a single } \\
\text { instrument run along with the associated } \\
\text { QC samples) }\end{array}$ \\
\hline Analyst's initials ${ }^{a}$ & 198-200 & Alpha & Initials of the analyst \\
\hline Percent solids & $201-205$ & Numeric & $\begin{array}{l}\text { Percentage of the sample that is dry } \\
\text { solids; required field if result is reported } \\
\text { in per mass units; not applicable for water } \\
\text { samples }\end{array}$ \\
\hline Bottle label number & $206-215$ & Integer & $\begin{array}{l}\text { Number on the bottle label; required field } \\
\text { if bottle label is numbered }\end{array}$ \\
\hline Sample fraction & 216-219 & Alphanumeric & $\begin{array}{l}\text { EPD/EMS identifier for the fraction of the } \\
\text { sample analyzed (see table C.9) }\end{array}$ \\
\hline Validation status & $220-221$ & Alphanumeric & $\begin{array}{l}0=\text { Unvalidated (used by laboratory) } \\
3=\text { Validated definitive data }\end{array}$ \\
\hline EPD/EMS receipt date & $222-227$ & Numeric & $\begin{array}{l}\text { Date that the analytical data are received } \\
\text { by EPD/EMS from the laboratory. The } \\
\text { laboratory leaves this blank }\end{array}$ \\
\hline ESH-EMS number & $228-234$ & Alphanumeric & $\begin{array}{l}\text { Document number assigned to the project } \\
\text { report }\end{array}$ \\
\hline
\end{tabular}


Table C. 6 is a description of the analytical data format, AN95-R1.B which is used for coding and transmitting a subset of the AN95 analytical data records.

Table C.6 Analytical Data Format AN95-R1.B

\begin{tabular}{|c|c|c|c|}
\hline Name & Columns & Type & Description \\
\hline WSRC identifier & $1-12$ & Numeric & WSRC identifier for the sample \\
\hline Station identifier & $13-23$ & Alphanumeric & $\begin{array}{l}\text { Identification of the actual sample } \\
\text { (includes any modification made in the } \\
\text { field) }\end{array}$ \\
\hline Top of interval & $24-29$ & Numeric & $\begin{array}{l}\text { Depth from the ground to the top of the } \\
\text { actual sampling interval to the nearest } \\
0.01 \mathrm{ft}\end{array}$ \\
\hline Bottom of interval & $30-35$ & Numeric & $\begin{array}{l}\text { Depth from the ground to the bottom of } \\
\text { the actual sampling interval to the } \\
\text { nearest } 0.01 \mathrm{ft}\end{array}$ \\
\hline Sample collection date & $36-42$ & Numeric & $\begin{array}{l}\text { Date sample was collected. Enter the } \\
\text { preparation date for laboratory blanks } \\
\text { and QC samples; enter the date of } \\
\text { completion of TCLP sample generation for } \\
\text { TCLP samples }\end{array}$ \\
\hline Laboratory replicate & $43-45$ & Alphanumeric & $\begin{array}{l}\text { Indicates that the sample is a non-blind } \\
\text { replicate analysis (see table C.8) }\end{array}$ \\
\hline Analyte name & $46-95$ & Alphanumeric & Full analyte name \\
\hline Analytical method & $96-108$ & Alphanumeric & $\begin{array}{l}\text { Coded identifier for the method used to } \\
\text { perform the analysis (e.g., EPA\#\#\#.\#) }\end{array}$ \\
\hline Quantitation limit & $109-116$ & Numeric & $\begin{array}{l}\text { GE and WA report the ssEQL for non- } \\
\text { radiochemistry analyses; all labs report } \\
\text { the MDA for radiochemistry analyses }\end{array}$ \\
\hline Result qualifier & $117-119$ & Alphanumeric & $\begin{array}{l}\text { Coded field used to qualify the analytical } \\
\text { result (see table D.1) }\end{array}$ \\
\hline Result & $120-129$ & Numeric & $\begin{array}{l}\text { Concentration of the analyte. For non- } \\
\text { detects, the ssEQL is reported. Results } \\
\text { were reported on a dry weight basis for all } \\
\text { analyses reported in per mass units } \\
\end{array}$ \\
\hline Analysis qualifier & $130-132$ & Alphanumeric & $\begin{array}{l}\text { Coded field used to qualify the analytical } \\
\text { result (see table D.2) }\end{array}$ \\
\hline Bias of analysis & $133-134$ & Alpha & $\begin{array}{l}\text { Coded field for specifying the expected } \\
\text { bias (see table D.3) }\end{array}$ \\
\hline Result unit & $135-140$ & Alpha & $\begin{array}{l}\text { Unit in which the analytical result is } \\
\text { reported }\end{array}$ \\
\hline Validation status & $141-142$ & Alphanumeric & $\begin{array}{l}0=\text { Unvalidated (used by laboratory) } \\
3=\text { Validated definitive data }\end{array}$ \\
\hline $\begin{array}{l}\text { ESH-EMS document } \\
\text { number }\end{array}$ & $143-149$ & Alphanumeric & $\begin{array}{l}\text { Document number assigned to the project } \\
\text { report }\end{array}$ \\
\hline
\end{tabular}

Data Summary Report for the 1997 Semiannual Tritium Survey for Fourmile Branch and the F- and H-Area Seeplines (WSRC-TR-97-00414) 
Table C.7 is a description of the analytical data format, AN95-R2.B which is used for coding and transmitting a subset of the AN95 analytical data records.

Table C.7 Analytical Data Format AN95-R2.B

\begin{tabular}{|c|c|c|c|}
\hline Name & Columns & Type & Description \\
\hline Station identifier & $1-11$ & Alphanumeric & $\begin{array}{l}\text { Identification of the actual sample } \\
\text { (includes any modification made in the } \\
\text { field) }\end{array}$ \\
\hline Top of interval & $12-17$ & Numeric & $\begin{array}{l}\text { Depth from the ground to the top of the } \\
\text { actual sampling interval to the nearest } \\
0.01 \mathrm{ft}\end{array}$ \\
\hline Bottom of interval & $18-23$ & Numeric & $\begin{array}{l}\text { Depth from the ground to the bottom of } \\
\text { the actual sampling interval to the } \\
\text { nearest } 0.01 \mathrm{ft}\end{array}$ \\
\hline Sample collection date & $24-30$ & Numeric & $\begin{array}{l}\text { Date sample was collected. Enter the } \\
\text { preparation date for laboratory blanks } \\
\text { and QC samples; enter the date of } \\
\text { completion of TCLP sample generation for } \\
\text { TCLP samples }\end{array}$ \\
\hline Laboratory replicate & $31-43$ & Alphanumeric & $\begin{array}{l}\text { Indicates that the sample is a non-blind } \\
\text { replicate analysis (see table C.8) }\end{array}$ \\
\hline Analyte name & $44-83$ & Alphanumeric & Full analyte name \\
\hline Analysis type & $84-93$ & Alphanumeric & Analytical suite \\
\hline Quantitation limit & $95-102$ & Numeric & $\begin{array}{l}\text { GE and WA report the ssEQL for non- } \\
\text { radiochemistry analyses; all labs report } \\
\text { the MDA for radiochemistry analyses }\end{array}$ \\
\hline Result qualifier & $103-105$ & Alphanumeric & $\begin{array}{l}\text { Coded field used to qualify the analytical } \\
\text { result (see table D.1) }\end{array}$ \\
\hline Result & $106-115$ & Numeric & $\begin{array}{l}\text { Concentration of the analyte. For non- } \\
\text { detects, the } s s E Q L \text { is reported. Results } \\
\text { are reported on a dry weight basis for all } \\
\text { analyses reported in per mass units }\end{array}$ \\
\hline Result unit & $116-121$ & Alpha & $\begin{array}{l}\text { Unit in which the analytical result is } \\
\text { reported }\end{array}$ \\
\hline Validation status & $122-123$ & Alphanumeric & $\begin{array}{l}0=\text { Unvalidated (used by laboratory) } \\
3=\text { Validated definitive data }\end{array}$ \\
\hline $\begin{array}{l}\text { ESH-EMS document } \\
\text { number }\end{array}$ & $124-130$ & Alphanumeric & $\begin{array}{l}\text { Document number assigned to the project } \\
\text { report }\end{array}$ \\
\hline
\end{tabular}


When making entries in the laboratory replicate field of the data files, only the codes listed in table C.8 are used.

\section{Table C.8 Codes for Laboratory Replicates}

\begin{tabular}{|l|l|}
\hline Remark & Definition \\
\hline (blank) & Data not remarked; the result is a routine analysis of a sample \\
\hline 1 & Laboratory replicate \\
\hline 2A & Matrix spike \\
\hline 2B & Matrix spike duplicate \\
\hline 2C & Surrogate spike \\
\hline 2D & Blank spike \\
\hline 2E & Blank spike duplicate \\
\hline 3 & Laboratory blank \\
\hline 4 & Re-analysis of a sample at the request of EPD/EMS \\
\hline CCB & Continuing calibration blank \\
\hline CCV & Continuing calibration verification sample \\
\hline ICB & Initial calibration blank \\
\hline ICS & Interference check sample \\
\hline ICV & Initial calibration verification sample \\
\hline
\end{tabular}

When making entries in the sample fraction field of the data files, only the codes listed in table C.9 are used.

\section{Table C.9 Codes for Fractions}

\begin{tabular}{|l|l|}
\hline Code & Description \\
\hline (blank) & Sample was not fractionated prior to analysis \\
\hline A & Ashed fraction \\
\hline D & Dried fraction of a soil or sludge sample; not used with water samples \\
\hline F & Liquid fraction passing through a filter was analyzed \\
\hline SL & Liquid fraction of a sample separated from the solid fraction \\
\hline SS & Suspended soils \\
\hline T & TCLP extraction \\
\hline
\end{tabular}


When entering the identifiers for groundwater samples, the format listed in table C.10 is used for the WSRC identifier entered in the AN95 data file.

Table C.10 WSRC Identifier for Groundwater Samples

\begin{tabular}{|l|l|l|l|}
\hline Name & Columns & Type & Description \\
\hline Well name & & & Alpha \\
\hline Series name & $1-3$ & $\begin{array}{l}\text { Name of the well series (except 241-H) } \\
\text { from which the sample was collected; QC } \\
\text { laboratory deionized water samples have } \\
\text { LB (the first character is blank) as well } \\
\text { series designation }\end{array}$ \\
\hline Cluster number & $4-6$ & Numeric & Number of the cluster (except 241-H) \\
\hline Well within cluster & $7-8$ & Alphanumeric & Blank, if not applicable \\
\hline & $9-10$ & Blank & Unused \\
\hline $\begin{array}{l}\text { Duplicate } \\
\text { identification }\end{array}$ & 11 & Alphanumeric & $\begin{array}{l}\text { Assigned by field personnel to identify } \\
\text { different sampling events occurring in one } \\
\text { day }\end{array}$ \\
\hline Secondary identifier & 12 & Alphanumeric & $\begin{array}{l}\text { Used as an alternate identifier by the } \\
\text { Groundwater Monitoring group of } \\
\text { EPD/EMS }\end{array}$ \\
\hline
\end{tabular}




\section{D.1 Qualifiers}

The following qualifiers were applied to the analytical results during data validation.

\section{Table D.1 Result Qualifiers}

\begin{tabular}{|c|c|}
\hline Qualifier & Description \\
\hline (blank) & Data are not remarked. Value should be interpreted exactly as reported. \\
\hline $\mathrm{Ca}$ & $\begin{array}{l}\text { Calculated. Analytical result reported was not measured directly but was } \\
\text { calculated from other data available. This does not apply to conversions, nor does it } \\
\text { apply to calculations made as part of an analytical procedure. }\end{array}$ \\
\hline $\mathrm{D}^{\mathrm{a}}$ & Field measurement \\
\hline $\mathbf{I}$ & $\begin{array}{l}\text { The value in the result field is the instrument reading, not the sample quantitation } \\
\text { limit. Always used with the result qualifier } U \text {. }\end{array}$ \\
\hline $\mathrm{Jb}$ & The analytical result is an estimated quantity. \\
\hline $\mathrm{L}^{\mathrm{a}}$ & $\begin{array}{l}\text { Off-scale high. The actual value is not known but is known to be greater than value } \\
\text { shown. }\end{array}$ \\
\hline $\mathbf{R}^{\mathbf{a}}$ & $\begin{array}{l}\text { Result was rejected because performance requirements in the sample or associated } \\
\text { quality control analysis were not met. The analyte may or may not be present. }\end{array}$ \\
\hline $\mathrm{U}^{\mathrm{b}}$ & $\begin{array}{l}\text { Material analyzed for but not detected. The analyte concentration is less than the } \\
\text { ssEQL. NOTE: When both the result qualifier } U \text { and the result qualifier } I \text { are } \\
\text { reported, the numerical value in the result field is the instrument reading rather } \\
\text { than the ssEQL. }\end{array}$ \\
\hline
\end{tabular}

Table D.2 Analysis Qualifiers

\begin{tabular}{|l|l|}
\hline Qualifier & Description \\
\hline A & $\begin{array}{l}\text { GC/MS Compound Identification } \\
\text { Relative retention time or mass spectra criteria were not met. } \\
\text { Compound Identification } \\
\text { All anomalies }\end{array}$ \\
\hline B & $\begin{array}{l}\text { The result is below the sample quantitation limit and above or equal to the } \\
\text { instrument detection limit. }\end{array}$ \\
\hline C & $\begin{array}{l}\text { Laboratory Control Sample } \\
\text { Criteria were not met. }\end{array}$ \\
\hline D & $\begin{array}{l}\text { ICP Serial Dilution } \\
\text { Criteria were not met. }\end{array}$ \\
\hline E & $\begin{array}{l}\text { The detected result is between the sSEQL and the method detection limit. Report } \\
\text { the actual result detected. }\end{array}$ \\
\hline
\end{tabular}

a This code is based on the STORET codes from the U.S. EPA.

b This code is based on the CLP Laboratory Data Qualifiers from the U.S. EPA. 
Table D.2 Analysis Qualifiers (cont.)

\begin{tabular}{|c|c|}
\hline Qualifier & Description \\
\hline $\mathbf{F}$ & $\begin{array}{l}\text { Pesticides Compound Identification } \\
\text { Pesticide result has been confirmed by gas chromatography/mass spectrometry. }\end{array}$ \\
\hline G & $\begin{array}{l}\text { Pesticides Instrument Performance } \\
\text { Use for all conditions outside criteria other than those flagged } N \text { (see code } N \text { below). }\end{array}$ \\
\hline $\mathbf{H}$ & $\begin{array}{l}\text { Internal Standards Performance } \\
\text { Criteria not met }\end{array}$ \\
\hline $\bar{I}$ & $\begin{array}{l}\text { Matrix Spike/Matrix Spike Duplicate } \\
\text { Matrix Spike Sample Analysis } \\
\text { Spike recovery was not within control limits. }\end{array}$ \\
\hline $\mathrm{K}$ & $\begin{array}{l}\text { Tentatively Identified Compounds } \\
\text { A tentatively identified compound is a suspected aldol-condensation product. }\end{array}$ \\
\hline $\mathrm{L}$ & $\begin{array}{l}\text { Calibration Criteria Not Met } \\
\text { Calibration criteria (initial or continuing) were not met. See also } Z \text { for inorganics. }\end{array}$ \\
\hline $\mathbf{M}$ & $\begin{array}{l}\text { GC/MS Tuning } \\
\text { Mass calibration criteria not met. }\end{array}$ \\
\hline $\mathbf{N}$ & $\begin{array}{l}\text { Tentatively Identified Compounds } \\
\text { All TIC results }\end{array}$ \\
\hline $\mathrm{O}$ & $\begin{array}{l}\text { Surrogate Recovery } \\
\text { Surrogate spike recovery results are not within control limits. }\end{array}$ \\
\hline $\mathbf{P}$ & $\begin{array}{l}\text { Furnace Atomic Absorption QC } \\
\text { Duplicate injection precision criteria were not met, or post-digestion spike recovery } \\
\text { was not within control limits, but sample absorbance is greater than } 50 \% \text { of post- } \\
\text { digestion spike absorbance. }\end{array}$ \\
\hline $\bar{Q}$ & $\begin{array}{l}\text { Holding Time } \\
\text { Sample held beyond normal holding time. }\end{array}$ \\
\hline $\mathrm{R}$ & $\begin{array}{l}\text { ICP Interference Check Sample } \\
\text { Criteria not met }\end{array}$ \\
\hline $\mathbf{S}$ & The reported value was determined by the method of standard additions. \\
\hline $\mathrm{V}$ & $\begin{array}{l}\text { Method Blank Contamination } \\
\text { Indicates the analyte was detected in both the sample and associated method blank. }\end{array}$ \\
\hline $\mathrm{W}$ & $\begin{array}{l}\text { Furnace Atomic Absorption QC } \\
\text { Post-digestion spike recovery for furnace atomic absorption analysis is not within } \\
\text { control limits while sample absorbance is less than } 50 \% \text { of spike absorbance. }\end{array}$ \\
\hline $\mathrm{X}$ & $\begin{array}{l}\text { Matrix Spike/Matrix Spike Duplicates } \\
\text { Laboratory Duplicate Sample Analysis } \\
\text { Duplicate analysis relative percent difference is not within control limits. }\end{array}$ \\
\hline $\mathrm{Y}$ & Result obtained from unpreserved or improperly preserved sample. \\
\hline $\mathbf{Z}$ & $\begin{array}{l}\text { Calibration } \\
\text { Furnace Atomic Absorption QC } \\
\text { Correlation coefficient was less than } 0.995 \text {. }\end{array}$ \\
\hline 4 & Matrix interference; value cannot be determined. \\
\hline 5 & $\begin{array}{l}\text { The analytical value was four times higher than the standard concentration, and } \\
\text { percent recovery cannot be determined. }\end{array}$ \\
\hline
\end{tabular}

Data Summary Report for the 1997 Semiannual Tritium Survey

for Fourmile Branch and the F- and H-Area Seeplines (WSRC-TR-97-00414) 
Table D.2 Analysis Qualifiers (cont.)

\begin{tabular}{|l|l|}
\hline Qualifier & Description \\
\hline 6 & The analyte was detected in both the sample and associated field blank. \\
\hline 7 & $\begin{array}{l}\text { The analyte was detected in both the sample and associated rinsate or equipment } \\
\text { blank. }\end{array}$ \\
\hline 8 & The analyte was detected in both the sample and associated trip blank. \\
\hline 9 & $\begin{array}{l}\text { Field Duplicate Sample Analysis } \\
\text { Duplicate analysis relative percent difference is not within control limits. }\end{array}$ \\
\hline
\end{tabular}

Table D.3 Bias Qualifiers

\begin{tabular}{|l|l|}
\hline Qualifier & Description \\
\hline $\mathrm{L}$ & $\begin{array}{l}\text { Analytical factor causing bias. The associated result may underestimate the true } \\
\text { value. }\end{array}$ \\
\hline $\mathrm{H}$ & $\begin{array}{l}\text { Analytical factor causing bias. The associated result may overestimate the true } \\
\text { value. }\end{array}$ \\
\hline
\end{tabular}




\section{D.2 Number of Qualified Samples}

Tables D.4 and D.5 present the samples requested, received, and qualified for each analyte. Analytical results for both the primary laboratory and the laboratory receiving QC samples are included in the tables. Surrogates, matrix spikes, and other laboratory QC results are not included in the tables.

- The Samples Requested column contains the number of times the laboratory received a COC form and its associated sample (environmental samples, field-generated duplicates, field blanks, and trip blanks) requesting that a particular analysis be performed.

- The Samples Received column contains the total number of samples for which at least one analytical record was reported. Missing analyses are discussed in section 2.3.1, Missing Data, of this report.

- The Analyses Reported column contains the total number of reported results for the analyte. This number includes laboratory-initiated duplicate analyses and re-analysis results; it does not include analyses of associated laboratory blanks.

The remaining columns in the tables list the number of analyses that were qualified for meeting specified conditions.

- The column labeled Records Rejected contains the number of records for which the RQ was $R$. Samples having a rejected result also may have an acceptables reanalysis result.

- The column labeled Out of Holding contains the number of records for which the time between sample collection and analysis exceeded the maximum allowed by the analytical method. These records have an $\mathrm{AQ}$ of $Q$. All laboratory $\mathrm{pH}$ measurements exceed holding time, regardless of the laboratory's efficiency.

- The column labeled QC Problems contains the number of records having an AQ of $C$, $H, I, O, V$, or $X$ because at least one associated laboratory $\mathrm{QC}$ sample did not meet the required standards.

- The column labeled Preservation contains the number of records with preservation problems. These records have an AQ of $Y$.

- The column labeled Calibration contains the number of records with identified calibration problems. These records have an AQ of $L$. 
Table D.4 Number of Qualified Samples for FHST3

\begin{tabular}{|l|l|l|l|l|l|l|l|l|l|}
\hline Analyte & $\begin{array}{l}\text { Samples } \\
\text { Requested }\end{array}$ & $\begin{array}{l}\text { Samples } \\
\text { Received }\end{array}$ & $\begin{array}{l}\text { Analyses } \\
\text { Reported }\end{array}$ & $\begin{array}{l}\text { Records } \\
\text { Rejecteda }\end{array}$ & $\begin{array}{l}\text { Out of } \\
\text { Holdingb }\end{array}$ & $\begin{array}{l}\text { QC } \\
\text { Problems }\end{array}$ & $\begin{array}{l}\text { Preser- } \\
\text { vation }^{\mathbf{d}}\end{array}$ & $\begin{array}{l}\text { Calibra- } \\
\text { tione }\end{array}$ \\
\hline Radionuclides & \multicolumn{1}{|l|}{} \\
\hline Tritium & 65 & 65 & 68 & 0 & 0 & 3 & 0 \\
\hline
\end{tabular}

Table D.5 Number of Qualified Samples for FHST4

\begin{tabular}{|l|l|l|l|l|l|l|l|l|}
\hline Analyte & $\begin{array}{l}\text { Samples } \\
\text { Requested }\end{array}$ & $\begin{array}{l}\text { Samples } \\
\text { Received }\end{array}$ & $\begin{array}{l}\text { Analyses } \\
\text { Reported }\end{array}$ & $\begin{array}{l}\text { Records } \\
\text { Rejected }\end{array}$ & $\begin{array}{l}\text { Out of } \\
\text { Holding }\end{array}$ & $\begin{array}{l}\text { QC } \\
\text { Problems }\end{array}$ & $\begin{array}{l}\text { Preser- } \\
\text { vation }\end{array}$ & $\begin{array}{l}\text { Calibra- } \\
\text { tion }\end{array}$ \\
\hline Radionuclides & \multicolumn{10}{|l|l|l|l|l|l|}{} \\
\hline Tritium & 43 & 43 & 47 & 0 & 0 & 1 & 0 \\
\hline
\end{tabular}

a $\mathrm{RQ}=R$

b $\mathrm{AQ}=Q$

- $\mathrm{AQ}=C, H, I, O, V$, or $X$

d $\mathrm{AQ}=Y$

e $\mathrm{AQ}=L$ 
The numbers of analytical records sorted by analytical method and type of record are given in tables D.6 and D.7.

Table D.6 Number of Analytical Records by Method and Type of Record for FHST3

\begin{tabular}{|l|l|l|l|l|l|l|}
\hline Analytical Method & $\begin{array}{l}\text { Sample } \\
\text { Records }\end{array}$ & $\begin{array}{l}\text { Laboratory } \\
\text { Duplicates }\end{array}$ & $\begin{array}{l}\text { Laboratory } \\
\text { Blanks }\end{array}$ & $\begin{array}{l}\text { Matrix } \\
\text { Spikes }\end{array}$ & $\begin{array}{l}\text { Calibration } \\
\text { Checks }\end{array}$ & Totals \\
\hline 3Q161410 & 2 & 1 & 2 & 0 & 0 & 5 \\
\hline EPA906.0 & 63 & 2 & 10 & 2 & 0 & 77 \\
\hline
\end{tabular}

Table D.7 Number of Analytical Records by Method and Type of Record for FHST4

\begin{tabular}{|l|l|l|l|l|l|l|}
\hline Analytical Method & $\begin{array}{l}\text { Sample } \\
\text { Records }\end{array}$ & $\begin{array}{l}\text { Laboratory } \\
\text { Duplicates }\end{array}$ & $\begin{array}{l}\text { Laboratory } \\
\text { Blanks }\end{array}$ & $\begin{array}{l}\text { Matrix } \\
\text { Spikes }\end{array}$ & $\begin{array}{l}\text { Calibration } \\
\text { Checks }\end{array}$ & Totals \\
\hline EPA906.0 & 40 & 2 & 12 & 2 & 0 & 56 \\
\hline WSRC3Q161410 & 3 & 1 & 4 & 1 & 0 & 9 \\
\hline
\end{tabular}


Tables D.8 and D.9 list the minimum and maximum results for tritium, which was detected in all the routine environmental samples. These tables do not include field QC samples.

Table D.8 Analytes Detected in Environmental Samples for FHST3

\begin{tabular}{|l|l|l|l|}
\hline Analyte & Average Result & Minimum/Maximum MDA & Units \\
\hline Tritium & $1.53 \mathrm{E}+06$ & $6.29 \mathrm{E}+03 / 1.73 \mathrm{E}+07$ & $\mathrm{pCi} / \mathrm{L}$ \\
\hline
\end{tabular}

Table D.9 Analytes Detected in Environmental Samples for FHST4

\begin{tabular}{|l|l|l|l|}
\hline Analyte & Average Result & Minimum/Maximum MDA & Units \\
\hline Tritium & $2.57 \mathrm{E}+06$ & $2.94 \mathrm{E}+03 / 2.13 \mathrm{E}+07$ & $\mathrm{pCi} / \mathrm{L}$ \\
\hline
\end{tabular}




\section{D.3 Results Sorted by Sample}

Table D.10 Results Sorted by Sample for FHST3

SURVEY D: FHB 00103

Sample ID: 110547

Survey location: $54075 \mathrm{E}$ 73758N (SRS coordinates)

Sample type: Normal

Sample matrix: Water

Constituent

RQ AQ B Result

Unit ssEQL Method

Radionuclides

Tritium

$4.19 \mathrm{E}+04 \pm 4.37 \mathrm{E}+03 \mathrm{pCi} / \mathrm{L} \quad 5.62 \mathrm{E}+03 \quad \mathrm{EPA906.0}$

SURVEY ID: FHB 00203

Sample ID: 110546

Survey location: 54095E 73540 N (SRS coordinates)

Sample type: Normal

Sample matrix: Water

Constituent

RQ AQ B Result $\quad$ Unit ssEQL Method

Radionuclides

Tritium

1.23E+04 $\pm 9.29 \mathrm{E}+02 \mathrm{pCi} / \mathrm{L} \quad 9.48 \mathrm{E}+02 \mathrm{EPA} 906.0$

SURVEY ID: FHB 00303

Sample ID: 110558

Survey location: $53712 \mathrm{E} 73236 \mathrm{~N}$ (SRS coordinates)

Sample type: Normal

Sample matrix: Water

\section{Constituent}

RQ AQ B Result

Unit ssEQL Method

Radionuclides

Tritium

$1.01 \mathrm{E}+05 \pm 2.58 \mathrm{E}+03 \mathrm{pCi} / \mathrm{L} \quad 1.26 \mathrm{E}+03 \mathrm{EPA} 906.0$

SURVEY ID: FHB 00303D

Sample type: Split

Sample ID: 110559

Associated sample: 110558

Constituent

RQ AQ B Result

Unit ssEQL Method

3Q161410

Tritium

Tritium

I $\quad 1.16 \mathrm{E}+05 \pm 3.68 \mathrm{E}+03 \mathrm{pCi} / \mathrm{L} \quad 1.50 \mathrm{E}+063 \mathrm{Q} 161410$

I $\quad 1.14 \mathrm{E}+05 \pm 3.64 \mathrm{E}+03 \mathrm{pCi} / \mathrm{L} \quad 1.50 \mathrm{E}+063 \mathrm{Q} 161410$ 
SURVEY ID: FHB 00403

Sample ID: 110557

Survey location: 53741E 73029N (SRS coordinates)

Sample type: Normal

Sample matrix: Water

Constituent

RQ AQ B Result

Unit ssEQL Method

Radionuclides

Tritium

$1.58 \mathrm{E}+05 \pm 3.63 \mathrm{E}+03 \mathrm{pCi} / \mathrm{L} \quad 1.62 \mathrm{E}+03 \quad \mathrm{EPA} 906.0$

SURVEY ID: FHB 00503

Sample ID: 110561

Survey location: $53910 \mathrm{E} 72800 \mathrm{~N}$ (SRS coordinates)

Sample type: Normal

Sample matrix: Water

Constituent

RQ AQ B Result

Unit ssEQL Method

Radionuclides

Tritium

$4.35 \mathrm{E}+05 \pm 8.58 \mathrm{E}+03 \mathrm{pCi} / \mathrm{L} \quad 1.97 \mathrm{E}+03 \quad \mathrm{EPA} 906.0$

- SURVEY ID: FHB 00603

Sample ID: 110560

Survey location: $54129 \mathrm{E} 72672 \mathrm{~N}$ (SRS coordinates)

Sample type: Normal

Sample matrix: Water

Constituent

RQ AQ B Result

Unit ssEQL Method

Radionuclides

Tritium

$2.13 \mathrm{E}+05 \pm 4.23 \mathrm{E}+03 \mathrm{pCi} / \mathrm{L} \quad 1.08 \mathrm{E}+03 \mathrm{EPA} 906.0$

SURVEY ID: FHB 00803

Sample ID: 110562

Survey location: $54022 \mathrm{E} 72181 \mathrm{~N}$ (SRS coordinates)

Sample type: Normal

Sample matrix: Water

Constituent

RQ AQ B Result

Unit ssEQL Method

Radionuclides

Tritium

$1.11 \mathrm{E}+05 \pm 2.26 \mathrm{E}+03 \quad \mathrm{pCi} / \mathrm{L} \quad 8.53 \mathrm{E}+02 \mathrm{EPA906.0}$

SURVEY ID: FHB 01203

Sample ID: 110556

Survey location: 53878E 73424N (SRS coordinates)

Sample type: Normal

Sample matrix: Water

Constituent

RQ AQ B Result

Unit ssEQL Method

Radionuclides

Tritium

$1.73 \mathrm{E}+07 \pm 2.83 \mathrm{E}+05 \mathrm{pCi} / \mathrm{L} \quad 1.09 \mathrm{E}+04 \mathrm{EPA} 906.0$ 
SURVEY ID: FHB 01303

Sample ID: 110554

Survey location: $53848 \mathrm{E} 73508 \mathrm{~N}$ (SRS coordinates)

Sample type: Normal

Sample matrix: Water

Constituent

RQ AQ B Result

Unit ssEQL Method

Radionuclides

Tritium

$3.05 \mathrm{E}+06 \pm 5.89 \mathrm{E}+04 \mathrm{pCi} / \mathrm{L} \quad 6.42 \mathrm{E}+03 \mathrm{EPA} 906.0$

SURVEY ID: FHB 01403

Sample ID: 110555

Survey location: 53728E 73561N (SRS coordinates)

Sample type: Normal

Sample matrix: Water

Constituent

RQ AQ B Result

Unit ssEQL Method

Radionuclides

Tritium

$1.95 \mathrm{E}+05 \pm 3.89 \mathrm{E}+03 \quad \mathrm{pCi} / \mathrm{L} \quad 1.02 \mathrm{E}+03 \quad \mathrm{EPA} 906.0$

SURVEY ID: FHB 01603

Sample ID: 110548

Survey location: $54030 \mathrm{E} 73716 \mathrm{~N}$ (SRS coordinates)

Sample type: Normal

Sample matrix: Water

Constituent

RQ AQ B Result

Unit ssEQL Method

Radionuclides

Tritium

8.70E $+04 \pm 6.25 \mathrm{E}+03 \mathrm{pCi} / \mathrm{L} \quad 7.08 \mathrm{E}+03$ EPA906.0

SURVEY ID: FHB 01703

Sample ID: 110550

Survey location: $54000 \mathrm{E} 73668 \mathrm{~N}$ (SRS coordinates)

Sample type: Normal

Sample matrix: Water

Constituent

RQ AQ B Result

Unit ssEQL Method

Radionuclides

Tritium

$3.47 \mathrm{E}+06 \pm 6.75 \mathrm{E}+04 \mathrm{pCi} / \mathrm{L} \quad 7.40 \mathrm{E}+03 \mathrm{EPA} 906.0$

SURVEY ID: FHB 01803

Sample ID: 110551

Survey location: 54026E 73565N (SRS coordinates)

Sample type: Normal

Sample matrix: Water

Constituent

RQ AQ B Result

Unit ssEQL Method

Radionuclides

Tritium

$1.08 \mathrm{E}+07 \pm 2.02 \mathrm{E}+05 \mathrm{pCi} / \mathrm{L} \quad 1.30 \mathrm{E}+04 \mathrm{EPA} 906.0$ 
SURVEY ID: FHB 01903

Sample ID: 110553

Survey location: 53895E 73485N (SRS coordinates)

Sample type: Normal

Sample matrix: Water

Constituent

RQ AQ B Result

Unit ssEQL Method

Radionuclides

Tritium

$4.96 \mathrm{E}+06 \pm 9.53 \mathrm{E}+04 \mathrm{pCi} / \mathrm{L} \quad 9.88 \mathrm{E}+03 \mathrm{EPA} 906.0$

SURVEY ID: FHB 02003

Sample D: 110552

Survey location: $54008 E 73434 N$ (SRS coordinates)

Sample type: Normal

Sample matrix: Water

Constituent

RQ AQ B Result

Unit ssEQL Method

Radionuclides

Tritium

$1.63 \mathrm{E}+04 \pm 7.93 \mathrm{E}+02 \mathrm{pC} / \mathrm{L} \quad 6.33 \mathrm{E}+02 \mathrm{EPA} 906.0$

SURVEY ID: FMC001F03

Sample ID: 110563

Survey location: $57050 \mathrm{E} 70350 \mathrm{~N}$ (SRS coordinates)

Sample type: Normal

Sample matrix: Water

$\begin{array}{llllll}\text { Constituent } & \text { RQ AQ } & \text { Result } & \text { Unit } & \text { ssEQL Method } \\ \text { Radionuclides } & & & & \\ \text { Tritium } & & 3.29 \mathrm{E}+05 \pm 6.52 \mathrm{E}+03 & \mathrm{pCi} / \mathrm{L} & 1.37 \mathrm{E}+03 \text { EPA906.0 }\end{array}$

SURVEY ID: FMC001H02

Sample ID: 110609

Survey location: $5300 \mathrm{E} 72600 \mathrm{~N}$ (SRS coordinates)

Sample type: Normal

Sample matrix: Water

Constituent

RQ AQ B Result

Unit ssEQL Method

Radionuclides

Tritium

$9.07 \mathrm{E}+03 \pm 6.36 \mathrm{E}+02 \mathrm{pCi} / \mathrm{L} \quad 6.04 \mathrm{E}+02 \mathrm{EPA906.0}$

SURVEY D: FMC002H02

Sample ID: 110613

Survey location: 53000E $72600 \mathrm{~N}$ (SRS coordinates)

Sample type: Normal

Sample matrix: Water

Constituent

RQ AQ B Result

Unit ssEQL Method

Radionuclides

Tritium

$7.80 \mathrm{E}+04 \pm 1.61 \mathrm{E}+03 \mathrm{pCi} / \mathrm{L} \quad 6.51 \mathrm{E}+02 \mathrm{EPA} 906.0$ 
SURVEY ID: FSP 4703

Survey location:

Sample type: Normal

Constituent

Radionuclides

Tritium

SURVEY ID: FSP 00203
Sample ID: 110521

Sample matrix: Water

RQ AQ B Result Unit ssEQL Method

Survey location: 49133E 72796N (SRS coordinates)

Sample type: Normal

Constituent

RQ AQ

Radionuclides

Tritium

SURVEY ID: FSP 00703

Survey location: 49540E 73008N (SRS coordinates)

Sample type: Normal

Constituent

RQ AQ B Result

Radionuclides

Tritium

SURVEY ID: FSP 01203

Survey location: 49644E 73602N (SRS coordinates)

Sample type: Normal

Sample matrix: Water

Constituent

RQ AQ B Result

Unit ssEQL Method

Radionuclides

Tritium

$4.44 \mathrm{E}+04 \pm 1.30 \mathrm{E}+03 \mathrm{pCi} / \mathrm{L} \quad 6.81 \mathrm{E}+02 \mathrm{EPA} 906.0$
Sample matrix: Water

Unit ssEQL Method

$1.04 \mathrm{E}+06 \pm 2.04 \mathrm{E}+04 \mathrm{pCi} / \mathrm{L} \quad 3.65 \mathrm{E}+03$ EPA906.0

Sample ID: 110512

Unit ssEQL Method

pCi/L 1.56E+03 EPA906.0

Sample D: 110511

$\mathrm{pCi} / \mathrm{L} \quad 3.65 \mathrm{E}+03$ EPA906.0

(n)

SURVEY ID: FSP 01403

Survey location: 49802E $73685 N$ (SRS coordinates)

Sample type: Normal

Constituent

Radionuclides

Tritium

Tritium 
SURVEY ID: FSP 01903

Sample ID: 110514

Survey location: 49778E 73177N (SRS coordinates)

Sample type: Normal

Sample matrix: Water

Constituent

RQ AQ B Result

Unit ssEQL Method

Radionuclides

Tritium

$4.66 \mathrm{E}+06 \pm 8.96 \mathrm{E}+04 \mathrm{pCi} / \mathrm{L} \quad 8.06 \mathrm{E}+03 \mathrm{EPA} 906.0$

SURVEY ID: FSP 02603

Sample D: 110515

Survey location: 49801E 72932N (SRS coordinates)

Sample type: Normal

Sample matrix: Water

Constituent

RQ AQ B Result

Unit ssEQL Method

Radionuclides

Tritium

$6.77 \mathrm{E}+06 \pm 1.30 \mathrm{E}+05 \mathrm{pCi} / \mathrm{L} \quad 1.00 \mathrm{E}+04 \mathrm{EPA906.0}$

SURVEY ID: FSP 03203

Sample ID: 110516

Survey location: 50258E 73367N (SRS coordinates)

Sample type: Normal

Sample matrix: Water

Constituent

RQ AQ B Result

Unit ssEQL Method

Radionuclides

Tritium

$7.31 \mathrm{E}+04 \pm 1.52 \mathrm{E}+03 \quad \mathrm{pCi} / \mathrm{L} \quad 5.86 \mathrm{E}+02$ EPA906.0

SURVEY ID: FSP 03403

Sample D: 110518

Survey location: $50261 \mathrm{E} 73156 \mathrm{~N}$ (SRS coordinates)

Sample type: Normal

Sample matrix: Water

Constituent

RQ AQ B Result

Unit ssEQL Method

Radionuclides

Tritium

$2.18 \mathrm{E}+06 \pm 4.25 \mathrm{E}+04 \quad \mathrm{pCi} / \mathrm{L} \quad 5.41 \mathrm{E}+03 \mathrm{EPA906.0}$

SURVEY ID: FSP 03503

Sample ID: 110520

Survey location: 50297E 73065N (SRS coordinates)

Sample type: Normal

Sample matrix: Water

Constituent

RQ AQ B Result

Unit ssEQL Method

Radionuclides

Tritium

$5.09 \mathrm{E}+06 \pm 9.83 \mathrm{E}+04 \mathrm{pCi} / \mathrm{L} \quad 8.60 \mathrm{E}+03 \quad \mathrm{EPA} 906.0$

Data Summary Report for the 1997 Semiannual Tritium Survey

for Fourmile Branch and the F- and H-Area Seeplines (WSRC-TR-97-00414) 
Survey location: 50630E $73101 \mathrm{~N}$ (SRS coordinates)

Sample type: Normal Sample matrix: Water

Constituent RQ AQ B Result

Unit ssEQL Method

Radionuclides

Tritium $5.67 \mathrm{E}+06 \pm 1.13 \mathrm{E}+05 \mathrm{pCi} / \mathrm{L} \quad 9.76 \mathrm{E}+03$ EPA906.0

SURVEY ID: FSP 05603

Sample D: 110574

Survey location: $51488 E 73824 N$ (SRS coordinates)

Sample type: Normal

Sample matrix: Water

Constituent

RQ AQ B Result

Unit ssEQL Method

Radionuclides

Tritium

$6.29 \mathrm{E}+03 \pm 8.10 \mathrm{E}+02 \mathrm{pCi} / \mathrm{L} \quad 1.02 \mathrm{E}+03 \quad \mathrm{EPA} 906.0$

SURVEY ID: FSP 05603A

Sample ID: 110575

Sample type: Duplicate

Associated sample: 110574

Constituent

RQ AQ B Result

Unit ssEQL Method

Radionuclides

Tritium

$5.91 \mathrm{E}+03 \pm 5.83 \mathrm{E}+02 \quad \mathrm{pCi} / \mathrm{L} \quad 6.72 \mathrm{E}+02 \quad \mathrm{EPA9} 96.0$

SURVEY ID: FSP 20403

Sample ID: 110509

Survey location: 48801E 73281N (SRS coordinates)

Sample type: Normal

Sample matrix: Water

Constituent

RQ AQ B Result

Unit ssEQL Method

Radionuclides

Tritium

$2.40 \mathrm{E}+06 \pm 4.63 \mathrm{E}+04 \mathrm{pCi} / \mathrm{L} \quad 5.55 \mathrm{E}+03 \mathrm{EPA} 906.0$

SURVEY D: FSP 21303

Sample ID: 110506

Survey location: 48725E $73486 \mathrm{~N}$ (SRS coordinates)

Sample type: Normal

Sample matrix: Water

Constituent

RQ AQ B Result

Unit ssEQL , Method

Radionuclides

Tritium

$6.84 \mathrm{E}+05 \pm 1.35 \mathrm{E}+04 \mathrm{pCi} / \mathrm{L} \quad 2.55 \mathrm{E}+03 \quad \mathrm{EPA} 906.0$ 
SURVEY ID: FSP 22003

Sample ID: 110531

Survey location: 48644E 72983N (SRS coordinates)

Sample type: Normal

Sample matrix: Water

Constituent

RQ AQ B Result

Unit ssEQL Method

Radionuclides

Tritium

$5.05 \mathrm{E}+05 \pm 1.02 \mathrm{E}+04 \mathrm{pCi} / \mathrm{L} \quad 3.53 \mathrm{E}+03 \mathrm{EPA} 906.0$

SURVEY ID: FSP 22603

Sample ID: 110507

Survey location: 48601E 73308N (SRS coordinates)

Sample type: Normal

Sample matrix: Water

Constituent

RQ AQ B Result

Unit ssEQL Method

Radionuclides

Tritium

$7.58 \mathrm{E}+05 \pm 1.48 \mathrm{E}+04 \mathrm{pCi} / \mathrm{L} \quad 2.29 \mathrm{E}+03 \mathrm{EPA} 906.0$

SURVEY ID: FSP 23503

Sample ID: 110508

Survey location: 48587E 72979N (SRS coordinates)

Sample type: Normal

Sample matrix: Water

Constituent

RQ AQ B Result

Unit ssEQL Method

Radionuclides

Tritium

$2.42 \mathrm{E}+05 \pm 4.84 \mathrm{E}+03 \quad \mathrm{pCi} / \mathrm{L} \quad 1.36 \mathrm{E}+03 \mathrm{EPA} 906.0$

SURVEY ID: FSP 24103

Sample ID: 110503

Survey location: 48190E 72853N (SRS coordinates)

Sample type: Normal

Sample matrix: Water

Constituent

RQ AQ B Result

Unit ssEQL Method

Radionuclides

Tritium

$5.15 \mathrm{E}+05 \pm 1.02 \mathrm{E}+04 \mathrm{pCi} / \mathrm{L} \quad 2.04 \mathrm{E}+03 \mathrm{EPA} 906.0$

SURVEY 1D: FSP 24903

Sample ID: 110504

Survey location: 47905E 73107N (SRS coordinates)

Sample type: Normal

Sample matrix: Water

Constituent

RQ AQ B Result

Unit SsEQL Method

Radionuclides

Tritium

$1.93 \mathrm{E}+05 \pm 3.86 \mathrm{E}+03 \mathrm{pCi} / \mathrm{L} \quad 1.14 \mathrm{E}+03 \mathrm{EPA} 906.0$

Data Summary Report for the 1997 Semiannual Tritium Survey

for Fourmile Branch and the F- and H-Area Seeplines (WSRC-TR-97-00414) 
SURVEY ID: FSP 25603

Sample ID: 110505

Survey location: $47770 \mathrm{E} 73435 \mathrm{~N}$ (SRS coordinates)

Sample type: Normal

Sample matrix: Water

Constituent

RQ AQ B Result

Unit ssEQL Method

Radionuclides

Tritium

8.03E+04 $\pm 4.46 \mathrm{E}+03 \mathrm{pCi} / \mathrm{L} \quad 4.51 \mathrm{E}+03 \mathrm{EPA} 906.0$

SURVEY ID: FSP 27003

Sample ID: 110502

Survey location: $47411 \mathrm{E} 72805 \mathrm{~N}$ (SRS coordinates)

Sample type: Normal

Sample matrix: Water

Constituent

RQ AQ B Result

Unit ssEQL Method

Radionuclides

Tritium

$3.22 \mathrm{E}+04 \pm 1.18 \mathrm{E}+03 \quad \mathrm{pCi} / \mathrm{L} \quad 7.40 \mathrm{E}+02 \mathrm{EPA906.0}$

SURVEY ID: FSP 29003

Sample ID: 110500

Survey location: 46865E $73160 \mathrm{~N}$ (SRS coordinates)

Sample type: Normal

Sample matrix: Water

Constituent

RQ AQ B Result

Unit ssEQL Method

Radionuclides

Tritium

$2.38 \mathrm{E}+04 \pm 9.85 \mathrm{E}+02 \mathrm{pCi} / \mathrm{L} \quad 6.81 \mathrm{E}+02 \mathrm{EPA} 906.0$

SURVEY ID: FSP 29003A

Sample type: Duplicate

Sample ID: 110501

Associated sample: 110500

Constituent

RQ AQ B Result

Unit ssEQL Method

Radionuclides

Tritium

$2.56 \mathrm{E}+04 \pm 1.03 \mathrm{E}+03 \mathrm{pCi} / \mathrm{L} \quad 6.92 \mathrm{E}+02 \mathrm{EPA} 906.0$

SURVEY ID: HSP 00303

Sample ID: 110542

Survey location: 56879E 70711N (SRS coordinates)

Sample type: Normal

Sample matrix: Water

Constituent

RQ AQ B Result

Unit ssEQL Method

Radionuclides

Tritium

$1.48 \mathrm{E}+06 \pm 2.96 \mathrm{E}+04 \quad \mathrm{pCi} / \mathrm{L} \quad 9.33 \mathrm{E}+03 \quad \mathrm{EPA} 906.0$ 
SURVEY ID: HSP 00403

Sample ID: 110543

Survey location: $56819 \mathrm{E} 70710 \mathrm{~N}$ (SRS coordinates)

Sample type: Normal

Sample matrix: Water

Constituent

RQ AQ B Result

Unit ssEQL Method

Radionuclides

Tritium

$3.98 \mathrm{E}+05 \pm 7.83 \mathrm{E}+03 \mathrm{pCi} / \mathrm{L} \quad 1.56 \mathrm{E}+03 \mathrm{EPA} 906.0$

SURVEY ID: HSP 00803

Sample ID: 110540

Survey location: $56990 \mathrm{E} 71005 \mathrm{~N}$ (SRS coordinates)

Sample type: Normal

Sample matrix: Water

Constituent

RQ AQ B Result

Unit ssEQL Method

Radionuclides

Tritium

SURVEY ID: HSP 01103

$1.13 \mathrm{E}+06 \pm 2.22 \mathrm{E}+04 \mathrm{pCi} / \mathrm{L} \quad 2.81 \mathrm{E}+03 \mathrm{EPA906.0}$ Sample ID: 110541

Survey location: 57046E 71099N (SRS coordinates)

Sample type: Normal

Sample matrix: Water

Constituent

RQ AQ B Result

Unit ssEQL Method

Radionuclides

Tritium

$1.35 \mathrm{E}+05 \pm 4.88 \mathrm{E}+03 \quad \mathrm{pCj} / \mathrm{L} \quad 3.14 \mathrm{E}+03 \mathrm{EPA} 906.0$

SURVEY ID: HSP 01303

Sample ID: 110538

Survey location: $56878 \mathrm{E} 71056 \mathrm{~N}$ (SRS coordinates)

Sample type: Normal

Sample matrix: Water

\section{Constituent}

RQ AQ B Result

Unit ssEQL Method

Radionuclides

Tritium

$7.35 \mathrm{E}+05 \pm 1.45 \mathrm{E}+04 \mathrm{pCi} / \mathrm{L} \quad 3.12 \mathrm{E}+03 \mathrm{EPA} 906.0$

SURVEY ID: HSP 01503

Sample ID: 110537

Survey location: 56791E 71085N (SRS coordinates)

Sample type: Normal

Sample matrix: Water

\section{Constituent}

RQ AQ B Result

Unit ssEQL Method

Radionuclides

Tritium

$5.04 \mathrm{E}+05 \pm 9.99 \mathrm{E}+03 \mathrm{pCi} / \mathrm{L} \quad 2.15 \mathrm{E}+03 \quad \mathrm{EPA} 906.0$ 
SURVEY ID: HSP 02003

Sample ID: 110536

Survey location: $56849 \mathrm{E} 71142 \mathrm{~N}$ (SRS coordinates)

Sample type: Normal

Sample matrix: Water

Constituent

RQ AQ B Result

Unit ssEQL Method

Radionuclides

Tritium

$1.47 \mathrm{E}+05 \pm 7.00 \mathrm{E}+03 \mathrm{pCi} / \mathrm{L} \quad 6.53 \mathrm{E}+03 \quad \mathrm{EPA} 906.0$

SURVEY ID: HSP 02503

Sample ID: 110534

Survey location: 56297E 70960N (SRS coordinates)

Sample type: Normal

Sample matrix: Water

Constituent

RQ AQ B Result

Unit ssEQL Method

Radionuclides

Tritium

$2.58 \mathrm{E}+05 \pm 6.74 \mathrm{E}+03 \quad \mathrm{pCi} / \mathrm{L} \quad 3.33 \mathrm{E}+03 \quad \mathrm{EPA906.0}$

SURVEY ID: HSP 02903

Sample ID: 110535

Survey location: $56257 \mathrm{E} 71278 \mathrm{~N}$ (SRS coordinates)

Sample type: Normal

Sample matrix: Water

$\begin{array}{llll}\text { Constituent } & \text { RQ AQ B Result SsEQL Method }\end{array}$

Radionuclides

Tritium

$5.12 \mathrm{E}+04 \pm 1.30 \mathrm{E}+03 \mathrm{pCi} / \mathrm{L} \quad 6.25 \mathrm{E}+02 \mathrm{EPA} 906.0$

SURVEY ID: HSP 04303

Sample ID: 110529

Survey location: 55722E 71644N (SRS coordinates)

Sample type: Normal

Sample matrix: Water

Constituent

RQ AQ B Result

Unit ssEQL Method

Radionuclides

Tritium

$1.84 \mathrm{E}+06 \pm 3.61 \mathrm{E}+04 \mathrm{pCi} / \mathrm{L} \quad 4.97 \mathrm{E}+03 \quad \mathrm{EPA906.0}$

SURVEY ID: HSP 04603

Sample ID: 110533

Survey location: 56052E 71621N (SRS coordinates)

Sample type: Normal

Sample matrix: Water

Constituent

RQ AQ B Result

Unit ssEQL Method

Radionuclides

Tritium

$4.94 \mathrm{E}+05 \pm 9.91 \mathrm{E}+03 \quad \mathrm{pCi} / \mathrm{L} \quad 3.23 \mathrm{E}+03$ EPA906.0

Data Summary Report for the 1997 Semiannual Tritium Survey for Fourmile Branch and the F- and H-Area Seeplines (WSRC-TR-97-00414) 
SURVEY ID: HSP 04903

Sample ID: 110532

Survey location: $55987 \mathrm{E} 71389 \mathrm{~N}$ (SRS coordinates)

Sample type: Normal

Sample matrix: Water

Constituent

RQ AQ B Result

Unit ssEQL Method

Radionuclides

Tritium

$1.25 \mathrm{E}+06 \pm 2.45 \mathrm{E}+04 \mathrm{pCi} / \mathrm{L} \quad 4.13 \mathrm{E}+03$ EPA906.0

SURVEY ID: HSP 05203

Sample ID: 110530

Survey location: 55743E 71413N (SRS coordinates)

Sample type: Normal

Sample matrix: Water

Constituent

RQ AQ B Result

Unit ssEQL Method

Radionuclides .

Tritium

7.32E $+06 \pm 1.43 \mathrm{E}+05 \mathrm{pCi} / \mathrm{L} \quad 1.08 \mathrm{E}+04 \mathrm{EPA} 906.0$

SURVEY ID: HSP 05703

Sample ID: 110526

Survey location: $55516 \mathrm{E} 71567 \mathrm{~N}$ (SRS coordinates)

Sample type: Normal

Sample matrix: Water

Constituent

RQ AQ B Result

Unit ssEQL Method

Radionuclides

Tritium

$3.54 \mathrm{E}+05 \pm 7.04 \mathrm{E}+03 \mathrm{pCi} / 1.91 \mathrm{E}+03$ EPA906.0

SURVEY ID: HSP 06003

Sample ID: 110525

Survey location: $55190 \mathrm{E} 71629 \mathrm{~N}$ (SRS coordinates)

Sample type: Normal

Sample matrix: Water

Constituent

RQ AQ B Result

Unit ssEQL Method

Radionuclides

Tritium

1.47E+06 $2.87 \mathrm{E}+04 \mathrm{pCi} / \mathrm{L} \quad 4.38 \mathrm{E}+03$ EPA906.0

SURVEY ID: HSP 06403

Sample ID: 110576

Survey location: $54768 \mathrm{E} 71846 \mathrm{~N}$ (SRS coordinates)

Sample type: Normal

Sample matrix: Water

Constituent

RQ AQ B Result

Unit ssEQL Method

Radionuclides

Tritium

1.36E+04 $\pm 7.53 \mathrm{E}+02 \mathrm{pCi} / \mathrm{L} \cdot 6.51 \mathrm{E}+02 \mathrm{EPA} 906.0$

Data Summary Report for the 1997 Semiannual Tritium Survey

for Fourmile Branch and the F- and H-Area Seeplines (WSRC-TR-97-00414) 
SURVEY ID: HSP 06403A

Sample type: Duplicate

Constituent

Radionuclides

Tritium
Sample ID: 110577

Associated sample: 110576

RQ AQ B Result Unit ssEQL Method

SURVEY ID: HSP 07103

$1.45 \mathrm{E}+04 \pm 7.64 \mathrm{E}+02 \mathrm{pCi} / \mathrm{L} \quad 6.41 \mathrm{E}+02 \mathrm{EPA} 906.0$

Survey location: 54937E 71588N (SRS coordinates)

Sample type: Normal

Sample matrix: Water

Constituent

RQ AQ B Result

Unit ssEQL Method

Radionuclides

Tritium

$1.07 \mathrm{E}+06 \pm 2.12 \mathrm{E}+04 \mathrm{pCi} / \mathrm{L} \quad 2.54 \mathrm{E}+03 \quad \mathrm{EPA} 906.0$

SURVEY ID: HSP 07603

Sample ID: 110522

Survey location: 54571E 71494N (SRS coordinates)

Sample type: Normal

Sample matrix: Water

Constituent

RQ AQ B Result

Unit ssEQL Method

Radionuclides

Tritium

$2.02 \mathrm{E}+05 \pm 4.01 \mathrm{E}+03 \mathrm{pCi} / \mathrm{L} \quad 1.05 \mathrm{E}+03$ EPA906.0

SURVEY D: HSP 07603D

Sample type: Split

Sample ID: 110523

Associated sample: 110522

Constituent

RQ AQ B Result

Unit ssEQL Method

Radionuclides

Tritium

SURVEY ID: HSP 09703

Sample ID: 110545

Survey location: $54029 \mathrm{E} 72371 \mathrm{~N}$ (SRS coordinates)

Sample type: Normal

Sample matrix: Water

Constituent

RQ AQ B Result

Unit ssEQL Method

Radionuclides

Tritium

$1.37 \mathrm{E}+06 \pm 2.69 \mathrm{E}+04 \mathrm{pCi} / \mathrm{L} \quad 4.19 \mathrm{E}+03$ EPA906.0 
SURVEY ID: HSP 10303

Sample I: 110544

Survey location: 53665E $72448 \mathrm{~N}$ (SRS coordinates)

Sample type: Normal

Sample matrix: Water

Constituent

RQ AQ B Result

Unit ssEQL Method

Radionuclides

Tritium

9.27E $+05 \pm 1.82 \mathrm{E}+04 \mathrm{pCi} / \mathrm{L} \quad 2.32 \mathrm{E}+03$ EPA906.0

Tritium

$8.95 \mathrm{E}+05 \pm 1.76 \mathrm{E}+04 \mathrm{pCi} / \mathrm{L} \quad 2.18 \mathrm{E}+03 \mathrm{EPA} 906.0$ 


\section{Table D.11 Results Sorted by Sample for FHST4}

SURVEY ID: FHB 01204

Sample ID: 111731

Survey location: $53878 \mathrm{E} 73424 \mathrm{~N}$ (SRS coordinates)

Sample type: Normal

Sample matrix: Water

Constituent

RQ AQ B Result

Unit ssEQL Method

Radionuclides

Tritium

$2.13 \mathrm{E}+07 \pm 3.58 \mathrm{E}+05 \mathrm{pCi} / \mathrm{L} \quad 1.30 \mathrm{E}+04 \quad \mathrm{EPA906.0}$

SURVEY ID: FHB 01304

Sample ID: 111730

Survey location: 53848E 73508N (SRS coordinates)

Sample type: Normal

Sample matrix: Water

Constituent

RQ AQ B Result

Unit ssEQL Method

Radionuclides

Tritium

$6.66 \mathrm{E}+06 \pm 1.34 \mathrm{E}+05 \mathrm{pCi} / \mathrm{L}$

4.36E+04 EPA906.0

SURVEY ID: FHB 01404

Sample ID: 111762

Survey location: 53728E 73561N (SRS coordinates)

Sample type: Normal

Sample matrix: Water

Constituent

RQ AQ B Result

Unit

ssEQL Method

Radionuclides

Tritium

SURVEY ID: FHB 01704

Sample ID: 111727

Survey location: $54000 \mathrm{E} 73668 \mathrm{~N}$ (SRS coordinates)

Sample type: Normal

Sample matrix: Water

$\begin{array}{llllll}\text { Constituent } & \text { RQ AQ B Result } & \text { Unit ssEQ Method }\end{array}$

Radionuclides

Tritium

$2.11 \mathrm{E}+07 \pm 4.14 \mathrm{E}+05 \mathrm{pCi} / \mathrm{L}$

$5.89 \mathrm{E}+04 \quad$ EPA906.0

SURVEY ID: FHB 01804

Sample ID: 111726

Survey location: $54026 \mathrm{E} 73565 \mathrm{~N}$ (SRS coordinates)

Sample type: Normal

Sample matrix: Water

\section{Constituent}

RQ AQ B Result

Unit ssEQL Method

Radionuclides

Tritium

$3.06 \mathrm{E}+06 \pm 5.90 \mathrm{E}+04 \mathrm{pCi} / \mathrm{L}$

Tritium

$\begin{array}{llll}3.14 \mathrm{E}+06 \pm 6.12 \mathrm{E}+04 & \mathrm{pCi} / \mathrm{L} & 5.86 \mathrm{E}+03 & \mathrm{EPA} 906.0\end{array}$ 
SURVEY ID: FHB 02004

Sample ID: 111724

Survey location: 54008E 73434N (SRS coordinates)

Sample type: Normal

Sample matrix: Water

Constituent

RQ AQ B Result

Unit ssEQL Method

Radionuclides

Tritium

$7.81 \mathrm{E}+02$ EPA906.0

SURVEY ID: FMC001F04

Sample ID: 111760

Survey location: 57050E 70350N (SRS coordinates)

Sample type: Normal

Sample matrix: Water

\section{Constituent}

RQ AQ B Result

Unit ssEQL Method

Radionuclides

Tritium

$6.15 \mathrm{E}+05 \pm 1.21 \mathrm{E}+04 \mathrm{pCi} / \mathrm{L}$

1.85E+03 EPA906.0

SURVEY ID: FMC001F04A

Sample type: Duplicate

Constituent

Radionuclides

Tritium

SURVEY ID: FMC001H04

Survey location: 5300E 72600N (SRS coordinates)

Sample type: Normal

Constituent

Radionuclides

Tritium

SURVEY ID: FMC002H04

Survey location: 53000E $72600 \mathrm{~N}$ (SRS coordinates)

Sample type: Normal

RQ AQ B Result

\author{
Sample matrix: Water
}

$5.77 \mathrm{E}+05 \pm 1.13 \mathrm{E}+04 \mathrm{pCi} /$

$1.71 \mathrm{E}+03$ EPA906.0

Constituent

RQ AQ B Result

Unit

ssEQL Method

Radionuclides

Tritium

$6.05 \mathrm{E}+04 \pm 1.44 \mathrm{E}+03 \mathrm{pCi} / \mathrm{L}$

$6.34 \mathrm{E}+02 \quad \mathrm{EPA} 906.0$ 
SURVEY ID: FSP 00204

Sample ID: 111711

Survey location: 49133E 72796N (SRS coordinates)

Sample type: Normal Sample matrix: Water

Constituent

RQ AQ B Result

Unit ssEQL Method

Radionuclides

Tritium

$7.17 \mathrm{E}+05 \pm 1.40 \mathrm{E}+04 \mathrm{pCi} / \mathrm{L} \quad 1.89 \mathrm{E}+03 \quad \mathrm{EPA} 906.0$

SURVEY ID: FSP 00704

Sample ID: 111712

Survey location: 49540E 73008N (SRS coordinates)

Sample type: Normal

Sample matrix: Water

Constituent

RQ AQ B Result

Unit ssEQL Method

Radionuclides

Tritium

$1.00 \mathrm{E}+06 \pm 1.95 \mathrm{E}+04$

$\mathrm{pCi} / \mathrm{L}$

$2.49 \mathrm{E}+03$

EPA906.0

SURVEY ID: FSP 01204

Sample ID: 111713

Survey location: 49644E 73602N (SRS coordinates)

Sample type: Normal

Sample matrix: Water

Constituent

RQ AQ B Result

Unit ssEQL Method

Radionuclides

Tritium

$5.43 \mathrm{E}+04 \pm 1.36 \mathrm{E}+03 \mathrm{pCi} / \mathrm{L}$

$6.02 \mathrm{E}+02 \quad$ EPA906.0

SURVEY ID: FSP 01904

Sample ID: 111715

Survey location: $49778 \mathrm{E} 73177 \mathrm{~N}$ (SRS coordinates)

Sample type: Normal

Sample matrix: Water

Constituent

RQ AQ B Result

Unit ssEQL Method

Radionuclides

Tritium

$3.00 \mathrm{E}+06 \pm 5.82 \mathrm{E}+04 \mathrm{pCi} / \mathrm{L}$

$4.51 \mathrm{E}+03$ EPA906.0

SURVEY ID: FSP 02604

Sample ID: 111716

Survey location: 49801E 72932N (SRS coordinates)

Sample type: Normal

Sample matrix: Water

Constituent

RQ AQ B Result

Unit ssEQL Method

Radionuclides

Tritium

1.24E+04 EPA906.0 
SURVEY ID: FSP 03504

Sample ID: 111719

Survey location: 50297E 73065N (SRS coordinates)

Sample type: Normal

Sample matrix: Water

Constituent

RQ AQ B Result

Unit ssEQL Method

Radionuclides

Tritium

$8.38 \mathrm{E}+06 \pm 1.67 \mathrm{E}+05 \mathrm{pCi} / \mathrm{L}$

4.63E+04 EPA906.0

SURVEY ID: FSP 04004

Sample ID: 111720

Survey location: 50630E 73101N (SRS coordinates)

Sample type: Normal

Sample matrix: Water

Constituent

RQ AQ B Result

Unit ssEQL Method

Radionuclides

Tritium

$3.97 \mathrm{E}+06 \pm 7.90 \mathrm{E}+04 \mathrm{pCi} / \mathrm{L}$

$2.30 \mathrm{E}+04$

EPA906.0

SURVEY ID: FSP 04704

Sample ID: 111721

Survey location: 50607E 73609N (SRS coordinates)

Sample type: Normal

Sample matrix: Water

Constituent

RQ AQ B Result

Unit ssEQL Method

Radionuclides

Tritium

$1.14 \mathrm{E}+05 \pm 2.26 \mathrm{E}+03$

$\mathrm{pCi} / \mathrm{L}$

$7.09 \mathrm{E}+02$

EPA906.0

SURVEY ID: FSP 04704D

Sample ID: 111722

Sample type: Split

Associated sample: 111721

Constituent

RQ AQ

B Result

Unit

ssEQL் Method

WSRC3Q16

Tritium

$1.19 \mathrm{E}+05 \pm 2.50 \mathrm{E}+03 \mathrm{pCi} / \mathrm{L}$

$1.50 \mathrm{E}+03$

WSRC3Q161410

Tritium $1.18 \mathrm{E}+05 \pm 2.48 \mathrm{E}+03 \mathrm{pCi} / \mathrm{L}$

$1.50 \mathrm{E}+03$

WSRC3Q161410

SURVEY ID: FSP 05604

Sample ID: 111723

Survey location: $51488 \mathrm{E} 73824 \mathrm{~N}$ (SRS coordinates)

Sample type: Normal

Sample matrix: Water

\section{Constituent}

RQ AQ B Result

Unit ssEQL Method

Radionuclides

Tritium

J C

$9.02 \mathrm{E}+03 \pm 3.58 \mathrm{E}+03 \mathrm{pCi} / \mathrm{L}$

$5.57 \mathrm{E}+03$

EPA906.0

Data Summary Report for the 1997 Semiannual Tritium Survey for Fourmile Branch and the F- and H-Area Seeplines (WSRC-TR-97-00414) 
SURVEY ID: FSP 20404

Sample ID: 111710

Survey location: 48801E $73281 N$ (SRS coordinates)

Sample type: Normal

Sample matrix: Water

Constituent

RQ AQ B Result

Unit ssEQL Method

Radionuclides

Tritium

$2.07 \mathrm{E}+06 \pm 4.11 \mathrm{E}+04 \mathrm{pCi} / \mathrm{L}$

1.06E+04 EPA906.0

SURVEY ID: FSP 21304

Sample ID: 111709

Survey location: 48725E 73486N (SRS coordinates)

Sample type: Normal

Sample matrix: Water

Constituent

RQ AQ B Result

Unit ssEQL Method

Radionuclides

Tritium

$2.53 \mathrm{E}+06 \pm 4.86 \mathrm{E}+04 \mathrm{pCi} / \mathrm{L}$

4.09E+03 EPA906.0

SURVEY ID: FSP 22004

Sample ID: 111707

Survey location: 48644E 72983N (SRS coordinates)

Sample type: Normal

Sample matrix: Water

Constituent

RQ AQ B Result

Unit ssEQL Method

Radionuclides

Tritium

$8.47 \mathrm{E}+05 \pm 2.56 \mathrm{E}+04 \mathrm{pCi} / \mathrm{L}$

1.34E+04 EPA906.0

SURVEY ID: FSP 22604

Sample ID: 111708

Survey location: 48601E 73308 N (SRS coordinates)

Sample type: Normal

Sample matrix: Water

Constituent

RQ AQ B Result

Unit ssEQL Method

Radionuclides

Tritium

4.76E+05 $\pm 1.27 \mathrm{E}+04 \mathrm{pCi} / \mathrm{L}$

5.97E+03 EPA906.0

SURVEY ID: FSP 24104

Sample ID: 111705

Survey location: 48190E $72853 \mathrm{~N}$ (SRS coordinates)

Sample type: Normal

Sample matrix: Water

Constituent

RQ AQ B Result

Unit

ssEQL Method

Radionuclides

Tritium

$1.05 \mathrm{E}+06 \pm 2.09 \mathrm{E}+04 \mathrm{pCi} / \mathrm{L}$

$6.91 \mathrm{E}+03 \quad \mathrm{EPA} 906.0$ 
SURVEY D: FSP 24904

Sample ID: 111704

Survey location: 47905E 73107N (SRS coordinates)

Sample type: Normal

Sample matrix: Water

Constituent

RQ AQ B Result

Unit ssEQL Method

Radionuclides

Tritium

$7.02 \mathrm{E}+05 \pm 1.46 \mathrm{E}+04 \mathrm{pCi} / \mathrm{L}$

$5.50 \mathrm{E}+03$

EPA906.0

SURVEY ID: FSP 25604

Sample ID: 111703

Survey location: 47770E 73435N (SRS coordinates)

Sample type: Normal

Sample matrix: Water

Constituent

RQ AQ B Result

Unit ssEQL Method

Radionuclides

Tritium

$6.08 \mathrm{E}+05 \pm 1.19 \mathrm{E}+04 \mathrm{pCi} / \mathrm{L}$

$1.78 E+03 \quad$ EPA906.0

SURVEY ID: FSP 27004

Sample ID: 111702

Survey location: 47411E 72805N (SRS coordinates)

Sample type: Normal

Sample matrix: Water

Constituent RQ AQ B Result . Unit ssEQL Method

Radionuclides

Tritium

$4.69 \mathrm{E}+04 \pm 1.45 \mathrm{E}+03 \mathrm{pCi} / \mathrm{L} \quad 7.72 \mathrm{E}+02 \quad \mathrm{EPA906.0}$

SURVEY ID: FSP 29004

Sample ID: 111700

Survey location: 46865E 73160N (SRS coordinates)

Sample type: Normal

Sample matrix: Water

Constituent

RQ AQ B Result

Unit ssEQL Method

Radionuclides

Tritium

$4.10 \mathrm{E}+04 \pm 1.22 \mathrm{E}+03 \mathrm{pCi} / \mathrm{L}$

$6.28 \mathrm{E}+02$ EPA906.0

SURVEY ID: FSP 29004D

Sample ID: 111701

Sample type: Split

Associated sample: 111700

Constituent

RQ AQ B Result

Unit

ssEQL Method

WSRC3Q16

Tritium

$4.09 \mathrm{E}+04 \pm 1.57 \mathrm{E}+03 \mathrm{pCi} / \mathrm{L}$

1.50E+03 WSRC3Q161410

Data Summary Report for the 1997 Semiannual Tritium Survey for Fourmile Branch and the F- and H-Area Seeplines (WSRC-TR-97-00414) 
SURVEY ID: HSP 00804

Sample ID: 111747

Survey location: $56990 \mathrm{E} 71005 \mathrm{~N}$ (SRS coordinates)

Sample type: Normal

Sample matrix: Water

Constituent

RQ AQ B Result

Unit

SsEQL Method

Radionuclides

Tritium

$8.84 \mathrm{E}+05 \pm 1.75 \mathrm{E}+04 \mathrm{pCi} / \mathrm{L}$

$4.41 \mathrm{E}+03 \quad$ EPA906.0

SURVEY ID: HSP 01304

Sample ID: 111750

Survey location: $56878 \mathrm{E} 71056 \mathrm{~N}$ (SRS coordinates)

Sample type: Normal

Sample matrix: Water

Constituent

RQ AQ B Result

Unit

ssEQL Method

Radionuclides

Tritium

$1.65 \mathrm{E}+05 \pm 7.23 \mathrm{E}+03 \mathrm{pCi} / \mathrm{L}$

$5.06 \mathrm{E}+03 \quad$ EPA906.0

Tritium

SURVEY ID: HSP 01504

Sample ID: 111749

Survey location: 56791E 71085N (SRS coordinates)

Sample type: Normal

Sample matrix: Water

Constituent

RQ AQ B Result

Unit ssEQL Method

Radionuclides

Tritium

$5.93 \mathrm{E}+05 \pm 1.35 \mathrm{E}+04 \mathrm{pCi} / \mathrm{L}$

$5.51 \mathrm{E}+03 \quad \mathrm{EPA} 906.0$

SURVEY ID: HSP 02504

Sample ID: 111756

Survey location: 56297E 70960N (SRS coordinates)

Sample type: Normal

Sample matrix: Water

Constituent

RQ AQ B Result

Unit

ssEQL Method

Radionuclides

Tritium

$$
4.41 \mathrm{E}+05 \pm 8.70 \mathrm{E}+03 \mathrm{pCi} / \mathrm{L}
$$

$1.78 \mathrm{E}+03$ EPA906.0

SURVEY ID: HSP 02904

Sample ID: 111757

Survey location: 56257E 71278N (SRS coordinates)

Sample type: Normal

Sample matrix: Water

Constituent

RQ AQ B Result

Unit ssEQL Method

Radionuclides

Tritium

$6.21 \mathrm{E}+02 \quad \mathrm{EPA} 906.0$ 
SURVEY ID: HSP 04904

Sample ID: 111744

Survey location: 55987E 71389N (SRS coordinates)

Sample type: Normal

Sample matrix: Water

$\begin{array}{lllll}\text { Constituent } & \text { RQ AQ } & \text { B Result SsEQL Method }\end{array}$

Radionuclides

Tritium

$1.24 \mathrm{E}+06 \pm 4.70 \mathrm{E}+04 \mathrm{pCi} / \mathrm{L} \quad 2.91 \mathrm{E}+04 \quad \mathrm{EPA} 906.0$

SURVEY ID: HSP 05204

Sample ID: 111743

Survey location: 55743E 71413N (SRS coordinates)

Sample type: Normal

Sample matrix: Water

$\begin{array}{llllll}\text { Constituent } & \text { RQ AQ } & \text { B } & \text { Result } & \text { Unit } & \text { ssEQL Method }\end{array}$

Radionuclides

Tritium

$8.12 \mathrm{E}+06 \pm 1.53 \mathrm{E}+05 \mathrm{pCi} / \mathrm{L}$

1.01E+04 EPA906.0

SURVEY ID: HSP 07104

Sample ID: 111741

Survey location: 54937E $71588 \mathrm{~N}$ (SRS coordinates)

Sample type: Normal

Sample matrix: Water

Constituent

RQ AQ B Result

Unit ssEQL Method

Radionuclides

Tritium

$1.83 \mathrm{E}+06 \pm 3.50 \mathrm{E}+04 \mathrm{pCi} / \mathrm{L}$

$3.17 \mathrm{E}+03 \quad$ EPA906.0

SURVEY ID: HSP 07604

Sample ID: 111740

Survey location: $54571 \mathrm{E} 71494 \mathrm{~N}$ (SRS coordinates)

Sample type: Normal

Sample matrix: Water

Constituent

RQ AQ B Result

Unit ssEQL Method

Radionuclides

Tritium

$9.56 \mathrm{E}+04 \pm 1.92 \mathrm{E}+03$

$\mathrm{pCi} / \mathrm{L}$

$6.61 \mathrm{E}+02 \quad \mathrm{EPA} 906.0$

SURVEY ID: HSP 09704

Sample ID: 111751

Survey location: $54029 \mathrm{E} 72371 \mathrm{~N}$ (SRS coordinates)

Sample type: Normal

Sample matrix: Water

Constituent

RQ AQ B Result

Unit ssEQL Method

Radionuclides

Tritium

$1.58 \mathrm{E}+06 \pm 3.07 \mathrm{E}+04 \mathrm{pCi} / \mathrm{L}$

3.10E+03 EPA906.0 
SURVEY ID: HSP 09704A

Sample type: Duplicate

Constituent

Radionuclides

Tritium

SURVEY ID: HSP 10304

Survey location: $53665 \mathrm{E} 72448 \mathrm{~N}$ (SRS coordinates)

Sample type: Normal

Constituent

Radionuclides

Tritium

SURVEY ID: HSP 10304D

Sample type: Split

Constituent

Radionuclides

Tritium
Sample ID: 111752

Associated sample: 111751

RQ AQ B Result Unit ssEQL Method

$1.60 \mathrm{E}+06 \pm 3.11 \mathrm{E}+04 \mathrm{pCi} / \mathrm{L} \quad 2.85 \mathrm{E}+03 \quad \mathrm{EPA} 906.0$
Sample matrix: Water

RQ AQ B Result Unit ssEQL Method

$$
1.94 \mathrm{E}+06 \pm 3.77 \mathrm{E}+04 \mathrm{pCi} / \mathrm{L} \quad 3.30 \mathrm{E}+03 \quad \mathrm{EPA906.0}
$$

Sample ID: 111763

Associated sample: 111735

RQ AQ B Result Unit ssEQL Method

$1.96 \mathrm{E}+06 \pm 9.84 \mathrm{E}+03 \mathrm{pCi} / \mathrm{L} \quad 1.50 \mathrm{E}+03 \quad \mathrm{WSRC} 3 \mathrm{Q} 161410$ 


\section{D.4 Results Sorted by Analyte}

\section{Table D.12 Sample Results Sorted by Analyte for FHST3}

ANALYTE: Tritium
Analytical Group: Radionuclides

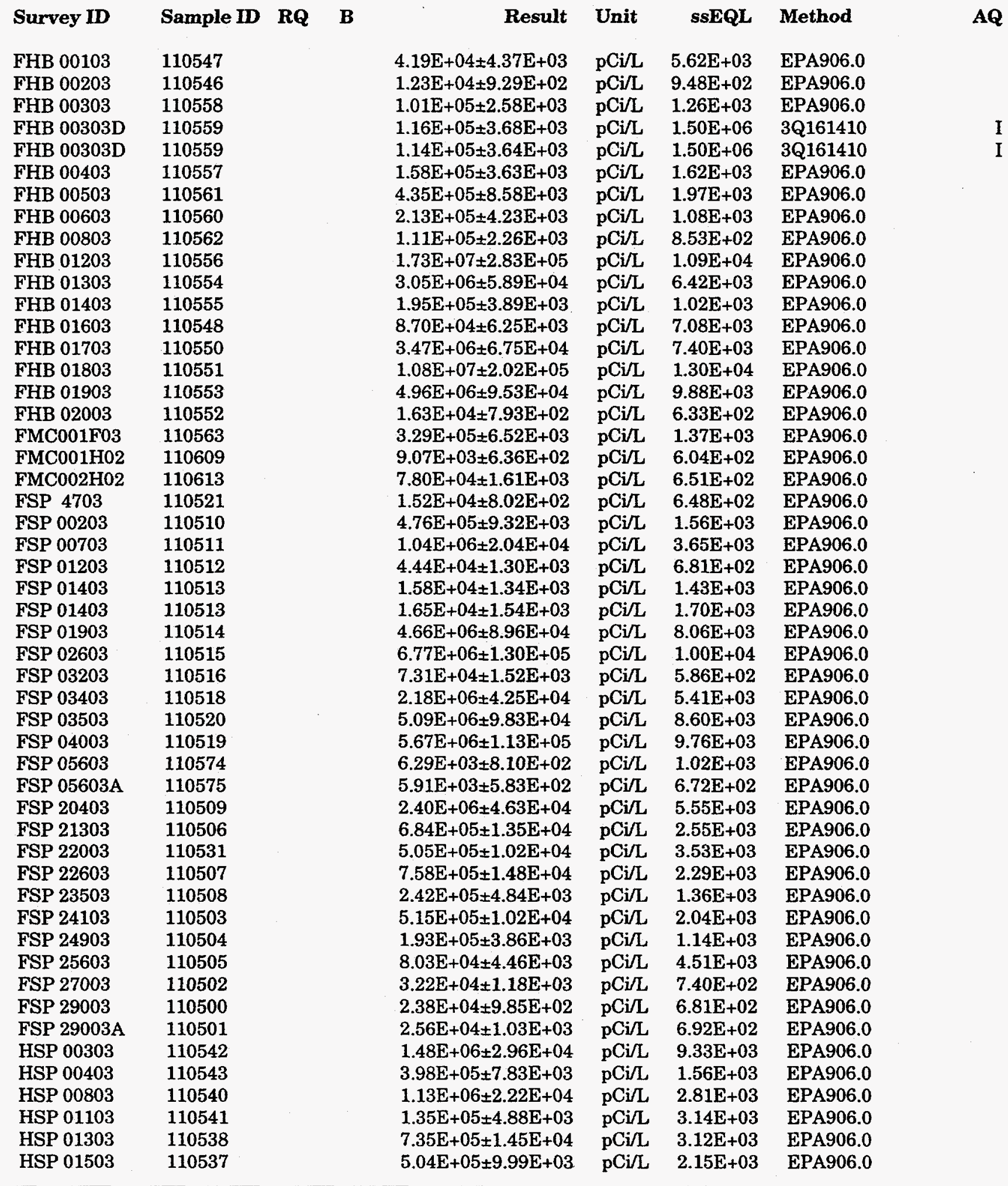


ANALYTE: Tritium (cont.)

\begin{tabular}{|c|c|c|c|c|c|c|}
\hline Survey ID & Sample ID RQ & $\mathbf{B}$ & Result & Unit & ssEQL & Method \\
\hline HSP 02003 & 110536 & & $1.47 \mathrm{E}+05 \pm 7.00 \mathrm{E}+03$ & $\mathrm{pCi} / \mathrm{L}$ & $6.53 \mathrm{E}+03$ & EPA906.0 \\
\hline HSP 02503 & 110534 & & $2.58 \mathrm{E}+05 \pm 6.74 \mathrm{E}+03$ & $\mathrm{pCi} / \mathrm{L}$ & $3.33 E+03$ & EPA906.0 \\
\hline HSP 02903 & 110535 & & $5.12 \mathrm{E}+04 \pm 1.30 \mathrm{E}+03$ & $\mathrm{pCi} / \mathrm{L}$ & $6.25 E+02$ & EPA906.0 \\
\hline HSP 04303 & 110529 & & $1.84 E+06 \pm 3.61 E+04$ & $\mathrm{pCi} / \mathrm{L}$ & $4.97 \mathrm{E}+03$ & EPA906.0 \\
\hline HSP 04603 & 110533 & & $4.94 \mathrm{E}+05 \pm 9.91 \mathrm{E}+03$ & $\mathrm{pCi} / \mathrm{L}$ & $3.23 \mathrm{E}+03$ & EPA906.0 \\
\hline HSP 04903 & 110532 & & $1.25 \mathrm{E}+06 \pm 2.45 \mathrm{E}+04$ & $\mathrm{pCi} / \mathrm{L}$ & $4.13 E+03$ & EPA906.0 \\
\hline HSP 05203 & 110530 & & $7.32 \mathrm{E}+06 \pm 1.43 \mathrm{E}+05$ & $\mathrm{pCi} / \mathrm{L}$ & $1.08 \mathrm{E}+04$ & EPA906.0 \\
\hline HSP 05703 & 110526 & & $3.54 \mathrm{E}+05 \pm 7.04 \mathrm{E}+03$ & $\mathrm{pCi} / \mathrm{L}$ & $1.91 E+03$ & EPA906.0 \\
\hline HSP 06003 & 110525 & & $1.47 \mathrm{E}+06 \pm 2.87 \mathrm{E}+04$ & $\mathrm{pCi} / \mathrm{L}$ & $4.38 \mathrm{E}+03$ & EPA906.0 \\
\hline HSP 06403 & 110576 & & $1.36 \mathrm{E}+04 \pm 7.53 \mathrm{E}+02$ & $\mathrm{pCi} / \mathrm{L}$ & $6.51 E+02$ & EPA906.0 \\
\hline HSP 06403A & 110577 & & $1.45 \mathrm{E}+04 \pm 7.64 \mathrm{E}+02$ & $\mathrm{pCi} / \mathrm{L}$ & $6.41 E+02$ & EPA906.0 \\
\hline HSP 07103 & 110524 & & $1.07 \mathrm{E}+06 \pm 2.12 \mathrm{E}+04$ & $\mathrm{pCi} / \mathrm{L}$ & $2.54 \mathrm{E}+03$ & EPA906.0 \\
\hline HSP 07603 & 110522 & & $2.02 \mathrm{E}+05 \pm 4.01 \mathrm{E}+03$ & $\mathrm{pCi} / \mathrm{L}$ & $1.05 \mathrm{E}+03$ & EPA906.0 \\
\hline HSP 07603D & 110523 & & $1.63 \mathrm{E}+05 \pm 1.19 \mathrm{E}+04$ & $\mathrm{pCi} / \mathrm{L}$ & $1.50 \mathrm{E}+06$ & 3Q161410 \\
\hline HSP 09703 & 110545 & & $1.37 \mathrm{E}+06 \pm 2.69 \mathrm{E}+04$ & $\mathrm{pCi} / \mathrm{L}$ & $4.19 E+03$ & EPA906.0 \\
\hline HSP 10303 & 110544 & & $9.27 \mathrm{E}+05 \pm 1.82 \mathrm{E}+04$ & $\mathrm{pCi} / \mathrm{L}$ & $2.32 \mathrm{E}+03$ & EPA906.0 \\
\hline HSP 10303 & 110544 & & $8.95 E+05 \pm 1.76 E+04$ & $\mathrm{pCi} / \mathrm{L}$ & $2.18 \mathrm{E}+03$ & EPA906.0 \\
\hline
\end{tabular}

$1.47 \mathrm{E}+05 \pm 7.00 \mathrm{E}+03$

$.58 \mathrm{E}+05 \pm 6.74 \mathrm{E}+03$

$1.84 \mathrm{E}+06+3.61 \mathrm{E}+04$ $4.94 \mathrm{E}+05 \pm 9.91 \mathrm{E}+03$

$1.25 \mathrm{E}+06 \pm 2.45 \mathrm{E}+04$

$+06+1.43 \mathrm{E}+05$

$1.45 \mathrm{E}+04+7.64 \mathrm{E}+02$

$1.07 \mathrm{E}+06 \pm 2.12 \mathrm{E}+04$

$2.02 \mathrm{E}+05 \pm 4.01 \mathrm{E}+03$

$137 \mathrm{E}+06 \pm 269 \mathrm{E}+04$

$8.95 \mathrm{E}+05 \pm 1.76 \mathrm{E}+04$

EPA906.0 
Table D.13 Sample Results Sorted by Analyte for FHST4

ANALYTE: Tritium
Analytical Group: Radionuclides

\begin{tabular}{|c|c|c|c|c|c|c|c|}
\hline Survey ID & Sample ID & $\mathbf{R Q}$ & $\mathbf{B}$ & Result & Unit & EQL & Method \\
\hline FHB 01204 & 111731 & & & $2.13 \mathrm{E}+07 \pm 3.58 \mathrm{E}+05$ & $\mathrm{pCi} / \mathrm{L}$ & $1.30 \mathrm{E}+04$ & EPA906.0 \\
\hline FHB 01304 & 111730 & & & $6.66 \mathrm{E}+06 \pm 1.34 \mathrm{E}+05$ & $\mathrm{pCi} / \mathrm{L}$ & $4.36 \mathrm{E}+04$ & EPA906.0 \\
\hline FHB 01404 & 111762 & & & $1.50 \mathrm{E}+06 \pm 2.96 \mathrm{E}+04$ & $\mathrm{pCi} / \mathrm{L}$ & $6.34 \mathrm{E}+03$ & EPA906.0 \\
\hline FHB 01704 & 111727 & & & $2.11 E+07 \pm 4.14 E+05$ & $\mathrm{pCi} / \mathrm{L}$ & $5.89 E+04$ & EPA906.0 \\
\hline FHB 01804 & 111726 & & & $3.06 \mathrm{E}+06 \pm 5.90 \mathrm{E}+04$ & $\mathrm{pCi} / \mathrm{L}$ & $5.68 \mathrm{E}+03$ & EPA906.0 \\
\hline FHB 01804 & 111726 & & , & $3.14 E+06 \pm 6.12 E+04$ & $\mathrm{pCi} / \mathrm{L}$ & $5.86 \mathrm{E}+03$ & EPA906.0 \\
\hline FHB 02004 & 111724 & . & & $2.94 \mathrm{E}+03 \pm 5.66 \mathrm{E}+02$ & $\mathrm{pCi} / \mathrm{L}$ & $7.81 \mathrm{E}+02$ & EPA906.0 \\
\hline FMC001F04 & 111760 & & & $6.15 \mathrm{E}+05 \pm 1.21 \mathrm{E}+04$ & $\mathrm{pCi} / \mathrm{L}$ & $1.85 \mathrm{E}+03$ & EPA906.0 \\
\hline FMC001F04A & 111764 & & & $5.77 \mathrm{E}+05 \pm 1.13 \mathrm{E}+04$ & $\mathrm{pCi} / \mathrm{L}$ & $1.71 \mathrm{E}+03$ & EPA906.0 \\
\hline FMC001H04 & 111746 & & & $1.63 \mathrm{E}+04 \pm 8.11 \mathrm{E}+02$ & $\mathrm{pCi} / \mathrm{L}$ & $6.39 E+02$ & EPA906.0 \\
\hline FMC002H04 & 111759 & & & $6.05 E+04 \pm 1.44 E+03$ & $\mathrm{pCi} / \mathrm{L}$ & $6.34 \mathrm{E}+02$ & EPA906.0 \\
\hline FSP 00204 & 111711 & & & $7.17 \mathrm{E}+05 \pm 1.40 \mathrm{E}+04$ & $\mathrm{pCi} / \mathrm{L}$ & $1.89 \mathrm{E}+03$ & EPA906.0 \\
\hline FSP 00704 & 111712 & & & $1.00 E+06 \pm 1.95 E+04$ & $\mathrm{pCi} / \mathrm{L}$ & $2.49 \mathrm{E}+03$ & EPA906.0 \\
\hline FSP 01204 & 111713 & & & $5.43 \mathrm{E}+04 \pm 1.36 \mathrm{E}+03$ & $\mathrm{pCi} / \mathrm{L}$ & $6.02 E+02$ & EPA906.0 \\
\hline FSP 01904 & 111715 & & & $3.00 E+06 \pm 5.82 E+04$ & $\mathrm{pCi} / \mathrm{L}$ & $4.51 E+03$ & EPA906.0 \\
\hline FSP 02604 & 111716 & & & $2.75 \mathrm{E}+06 \pm 5.42 \mathrm{E}+04$ & $\mathrm{pCi} / \mathrm{L}$ & $1.24 \mathrm{E}+04$ & EPA906.0 \\
\hline FSP 03504 & 111719 & & & $8.38 \mathrm{E}+06 \pm 1.67 \mathrm{E}+05$ & $\mathrm{pCi} / \mathrm{L}$ & $4.63 \mathrm{E}+04$ & EPA906.0 \\
\hline FSP 04004 & 111720 & & & $3.97 E+06 \pm 7.90 E+04$ & $\mathrm{pCi} / \mathrm{L}$ & $2.30 \mathrm{E}+04$ & EPA906.0 \\
\hline FSP 04704 & 111721 & & & $1.14 \mathrm{E}+05 \pm 2.26 \mathrm{E}+03$ & $\mathrm{pCi} / \mathrm{L}$ & $7.09 \mathrm{E}+02$ & EPA906.0 \\
\hline FSP 04704D & 111722 & & & $1.19 \mathrm{E}+05 \pm 2.50 \mathrm{E}+03$ & $\mathrm{pCi} / \mathrm{L}$ & $1.50 \mathrm{E}+03$ & WSRC3Q161410 \\
\hline FSP 04704D & 111722 & & & $1.18 \mathrm{E}+05 \pm 2.48 \mathrm{E}+03$ & $\mathrm{pCi} / \mathrm{L}$ & $1.50 \mathrm{E}+03$ & WSRC3Q161410 \\
\hline FSP 05604 & 111723 & $J$ & & $9.02 \mathrm{E}+03 \pm 3.58 \mathrm{E}+03$ & $\mathrm{pCi} / \mathrm{L}$ & $5.57 \mathrm{E}+03$ & EPA906.0 \\
\hline FSP 20404 & 111710 & & & $2.07 E+06 \pm 4.11 E+04$ & $\mathrm{pCi} / \mathrm{L}$ & $1.06 \mathrm{E}+04$ & EPA906.0 \\
\hline FSP 21304 & 111709 & & & $2.53 \mathrm{E}+06 \pm 4.86 \mathrm{E}+04$ & $\mathrm{pCi} / \mathrm{L}$ & $4.09 \mathrm{E}+03$ & EPA906.0 \\
\hline FSP 22004 & 111707 & & & $8.47 \mathrm{E}+05 \pm 2.56 \mathrm{E}+04$ & $\mathrm{pCi} / \mathrm{L}$ & $1.34 \mathrm{E}+04$ & EPA906.0 \\
\hline FSP 22604 & 111708 & & & $4.76 \mathrm{E}+05 \pm 1.27 \mathrm{E}+04$ & $\mathrm{pCi} / \mathrm{L}$ & $5.97 \mathrm{E}+03$ & EPA906.0 \\
\hline FSP 24104 & 111705 & & & $1.05 \mathrm{E}+06 \pm 2.09 \mathrm{E}+04$ & $\mathrm{pCi} / \mathrm{L}$ & $6.91 E+03$ & EPA906.0 \\
\hline FSP 24904 & 111704 & & & $7.02 \mathrm{E}+05 \pm 1.46 \mathrm{E}+04$ & $\mathrm{pCi} / \mathrm{L}$ & $5.50 \mathrm{E}+03$ & EPA906.0 \\
\hline FSP 25604 & 111703 & & & $6.08 \mathrm{E}+05 \pm 1.19 \mathrm{E}+04$ & $\mathrm{pCi} / \mathrm{L}$ & $1.78 \mathrm{E}+03$ & EPA906.0 \\
\hline FSP 27004 & 111702 & & & $4.69 E+04 \pm 1.45 E+03$ & pCi/ & $7.72 E+02$ & EPA906.0 \\
\hline FSP 29004 & 111700 & & & $4.10 \mathrm{E}+04 \pm 1.22 \mathrm{E}+03$ & $\mathrm{pCi} / \mathrm{L}$ & $6.28 E+02$ & EPA906.0 \\
\hline FSP 29004D & 111701 & & & $4.09 \mathrm{E}+04 \pm 1.57 \mathrm{E}+03$ & $\mathrm{pCi} / \mathrm{L}$ & $1.50 \mathrm{E}+03$ & WSRC3Q161410 \\
\hline HSP 00804 & 111747 & & & $8.84 \mathrm{E}+05 \pm 1.75 \mathrm{E}+04$ & $\mathrm{pCi} / \mathrm{L}$ & $4.41 E+03$ & EPA906.0 \\
\hline HSP 01304 & 111750 & & & $1.65 \mathrm{E}+05 \pm 7.23 \mathrm{E}+03$ & $\mathrm{pCi} / \mathrm{L}$ & $5.06 \mathrm{E}+03$ & EPA906.0 \\
\hline HSP 01304 & 111750 & & & $1.68 \mathrm{E}+05 \pm 7.45 \mathrm{E}+03$ & $\mathrm{pCi} / \mathrm{L}$ & $5.24 \mathrm{E}+03$ & EPA906.0 \\
\hline HSP 01504 & 111749 & & & $5.93 E+05 \pm 1.35 E+04$ & $\mathrm{pCi} / \mathrm{L}$ & $5.51 E+03$ & EPA906.0 \\
\hline HSP 02504 & 111756 & & & $4.41 \mathrm{E}+05 \pm 8.70 \mathrm{E}+03$ & $\mathrm{pCi} / \mathrm{L}$ & $1.78 \mathrm{E}+03$ & EPA906.0 \\
\hline HSP 02904 & 111757 & & & $3.76 \mathrm{E}+04 \pm 1.14 \mathrm{E}+03$ & $\mathrm{pCi} / \mathrm{L}$ & $6.21 E+02$ & EPA906.0 \\
\hline HSP 04904 & 111744 & & & $1.24 \mathrm{E}+06 \pm 4.70 \mathrm{E}+04$ & $\mathrm{pCi} / \mathrm{L}$ & $2.91 \mathrm{E}+04$ & EPA906.0 \\
\hline HSP 05204 & 111743 & & & $8.12 \mathrm{E}+06 \pm 1.53 \mathrm{E}+05$ & $\mathrm{pCi} / \mathrm{L}$ & $1.01 \mathrm{E}+04$ & EPA906.0 \\
\hline HSP 07104 & 111741 & & & $1.83 E+06 \pm 3.50 E+04$ & $\mathrm{pCi} / \mathrm{L}$ & $3.17 E+03$ & EPA906.0 \\
\hline HSP 07604 & 111740 & & & $9.56 \mathrm{E}+04 \pm 1.92 \mathrm{E}+03$ & $\mathrm{pCi} / \mathrm{L}$ & $6.61 \mathrm{E}+02$ & EPA906.0 \\
\hline HSP 09704 & 111751 & & & $1.58 \mathrm{E}+06 \pm 3.07 \mathrm{E}+04$ & $\mathrm{pCi} / \mathrm{L}$ & $3.10 E+03$ & EPA906.0 \\
\hline HSP 09704A & 111752 & & & $1.60 E+06 \pm 3.11 E \div 04$ & $\mathrm{pCi} / \mathrm{L}$ & $2.85 E+03$ & EPA906.0 \\
\hline HSP 10304 & 111735 & & & $1.94 \mathrm{E}+06 \pm 3.77 \mathrm{E}+04$ & $\mathrm{pCi} / \mathrm{L}$ & $3.30 \mathrm{E}+03$ & EPA906.0 \\
\hline HSP $10304 \mathrm{D}$ & 111763 & & & $1.96 \mathrm{E}+06 \pm 9.84 \mathrm{E}+03$ & $\mathrm{pCi} / \mathrm{L}$ & $1.50 \mathrm{E}+03$ & WSRC3Q161410 \\
\hline
\end{tabular}




\section{Appendix E: Data Management/Administrative Files}

This section discusses the generation, processing, and storage of paper and computer records produced during the completion of this project. The processing of the materials follows methodology prescribed by EGG EPD/EMS.

EGG establishes administrative files for each project that are maintained as permanent SRS records. The following materials are placed in the administrative files:

- Bound sample-collection logbooks

- Original copies of the chain-of-custody forms

- Case narratives from the laboratories

- Data-validation logbooks

- Data-entry cover sheets for data files created by EGG

- Copies of all correspondence between data validation personnel and the laboratories

EGG generates computer data files from paper records using double-entry methods to ensure a low transcription error rate. Computer data files for analytical data also are received from the laboratories. Changes to the data are recorded in the data-validation logbook, approved by the project technical manager, and confirmed through a computer program by comparing the modified and original data files. EGG stores the final computer data files, original source files, and computer listings of all changes made to the original files in the administrative files.

Access to the administrative files remains with the manager of EGG. Paper materials eventually will be transferred to permanent box storage; however, EGG plans to make the final data files available to SRS computer users indefinitely. Please contact the manager of EGG to obtain access to this data. 
Acceptance limits: The range of acceptable analytical results established by a laboratory for spike recovery, duplicate precision, and contamination levels.

Accuracy: The closeness of agreement between an observed value and an accepted reference value.

Activity: The rate of decay of a radioactive source at a given time.

Advisory range: The limits of acceptable analytical results established by the provider of certified quality control standards.

Aliquot: A measured portion of a sample taken for analysis.

Analysis: The separation and determination of the component parts or a specific property or element contained within a sample. The determination of the concentration or activity of an analyte contained within a sample.

Analysis date/time: The date and military time (24-hour clock) of the start of analysis on a prepared sample.

Analysis qualifier (AQ): See Qualifier.

Analyte: The specific compound, element, isotope, or radionuclide of interest that an analyst seeks to determine.

Analytical batch: A group of samples of the same matrix analyzed together using the same method and containing the required number of method blanks, matrix spike samples, laboratory control samples, and duplicate samples.

Analytical narrative: A portion of the data package that includes laboratory, contract, and sample identification. The analytical narrative also contains descriptive documentation of any problems encountered in processing the samples, along with corrective action taken and problems resolved.

Analytical sample: Any solution or medium introduced into an instrument on which an analysis is performed, excluding instrument calibration standards, calibration verification standards, and calibration blanks.

Appendix IX analytes: The list of analytes specified in Appendix IX of the Code of Federal Regulations, Title 40, Part 264 that is required by the Resource Conservation and Recovery Act.

Aquifer: A geologic formation, group of formations, or part of a formation capable of yielding groundwater to wells or springs.

Associated sample: Any sample that is related to another sample or quality control sample. Some examples are the parent sample of a matrix spike, a sample in a preparation batch, a split sample, a duplicate sample, and a sample related to a blank.

Data Summary Report for the 1997 Semiannual Tritium Survey 
Batch: A group of samples prepared at the same time, in the same location, using the same method.

\section{Bias qualifier (BQ): See Qualifier.}

Blank: An artificial sample designed to monitor the introduction of artifacts into the measurement process. For aqueous samples, deionized water is used as the blank matrix. A universal matrix does not exist for solid samples; therefore, no matrix blank is routinely used. There are several types of blanks that monitor a variety of processes. They are

- A Field Blank for Soils consists of DI water or dry quartz sand placed in a stainless steel bowl and exposed to the atmosphere while the associated sample is being taken. The field blank is shipped to the laboratory with the samples. The field blank measures contamination introduced during sample collection.

- A Field Blank for Groundwater is a sample container filled with DI water and capped in the WSRC well building. It is taken to the field during sampling, but is not opened. It is shipped to the laboratory with the samples to be analyzed.

- A Rinsate or Equipment Blank is deionized water poured over or through sample collection devices that tests for cleanliness of sampling equipment.

- A Trip Blank is shipped to the laboratory in the same cooler with the sample containers for volatile organic analytes. It provides a test for contamination from sample preservation and transport as well as sample storage, preparation, and analysis.

- A Method Blank is prepared in the laboratory and analyzed exactly as the samples it accompanies. It is a test for contamination in laboratory sample preparation and analyses.

These blanks are handled by the laboratory as actual samples; however, they are not to be used for matrix spike or duplicate samples.

\section{Blank spike (BS): See Laboratory Control Sample.}

Calibration: The establishment of an instrument response curve or mathematical correlation based on the measured response of known concentrations of an analyte or group of analytes.

Calibration blank: A volume of deionized water in the same matrix as the calibration standards, an empty planchet, or the instrument geometry that is analyzed to establish the instrument accuracy at the low end of the calibration curve.

Calibration verification: The periodic analysis of one or more standards independent of the calibration standards to verify the accuracy and stability of the initial instrument calibration.

Cation exchange capacity: The sum of exchangeable cations a soil can absorb expressed in milli-equivalents per 100 grams of soil. The cation exchange capacity is determined by sampling to the depth of solid waste placement and analyzing by the summation method for distinctly acid soils or the sodium acetate method for neutral, calcareous, or saline soils. 
Certified value: The known concentration of an analyte in a reference sample as affirmed by the preparer.

Chain-of-custody (COC) form: A document designed to trace the custody of a sample(s) from the point of origin to final disposition, with the intent of legally proving that custody remained intact and that tampering or substitutions were precluded.

Coefficient of variation (CV): The standard deviation as a percent of the arithmetic mean.

Comparability: The degree of confidence with which one set of data can be compared to a related set of data.

Completeness: A measure of the amount of valid data obtained from a measurement system relative to the amount that was expected to be obtained under current, normal conditions.

Comprehensive Environmental Response, Compensation, and Liability Act (CERCLA): A federal law passed in 1980 and periodically modified by the Superfund Amendments and Reauthorization Acts passed by the U.S. Congress. The acts created a special tax that goes into a trust fund, commonly known as Superfund, to investigate and clean up abandoned or uncontrolled hazardous waste sites. Under the program, the EPA has the following options:

- pay for the site cleanup when parties responsible for the contamination cannot be located or are unwilling or unable to perform the work

- take legal action to force parties responsible for site contamination to clean up the site or repay the federal government for the cost of the cleanup

Concentration: The relative fraction of one substance in another, normally expressed in weight percent, in volume percent, as a weight per volume ratio, or as a weight per weight ratio.

Confidence limits: The limits within which, at some specified level of probability, the true value of a result lies.

Confined aquifer: An aquifer bounded above and below by impermeable beds or by beds of distinctly lower permeability than the aquifer itself. Also, an aquifer containing confined groundwater.

Congener: Any one particular member of a class of chemical substances. A specific congener is denoted by a unique chemical structure e.g., 2,3,7,8-tetrachlorodibenzofuran.

Contaminant: A chemical or biological substance that is harmful if it is incorporated into, onto, or ingested by organisms, consumers of organisms, or users of the environment.

Continuing calibration blank (CCB): A blank analyzed periodically during an analytical run to detect carryover contamination.

Continuing calibration verification (CCV): The periodic analysis of one or more standards during an analytical run to verify that the initial calibration continues to be valid. 
Contract-required quantitation limit (CRQL): The lowest required concentration of an analyte the laboratory may report for a specific contract. The contract-required quantitation limit is usually greater than the method detection limit.

Control limits: A range within which specified measurement results must fall to be compliant. Control limits may be mandatory, requiring corrective action if exceeded, or advisory, requiring that noncompliant data be flagged.

Correlation coefficient (r): A numeric value ( $r$ ) that indicates the degree of dependence between two variables (concentration vs. response). The more dependent they are, the closer the value is to one. The correlation coefficient is determined on the basis of the least squares function.

Custody: Immediate charge, control, or possession exercised by a competent authority on a sample.

Data quality objectives: The objectives for precision, accuracy, representativeness, completeness, comparability, and detection levels that are required to support the intended use of the data.

Definitive data: Data for which the accuracy of the concentration level and the identity of the analyte of interest are assessed. Definitive data are determined for samples considered essential in the decision-making process.

Deionized (DI) water: Water from which all charged species or ionizable organic and inorganic salts are removed by means of ion exchange.

Detection: The act of measuring the quantity of a property, compound, or element contained in a sample.

Dilution factor: The mathematical factor by which a sample is diluted to bring the concentration of an analyte in the sample within the analytical range of the instrument (e.g., $1 \mathrm{~mL}$ of sample $+9 \mathrm{~mL}$ of solvent $=1: 10$ dilution, or a dilution factor of 10 ).

Dry weight: The weight of a sample based on percent solids or the weight after drying in an oven for a specified time period at a specified temperature.

Electronic data deliverable (EDD): The summary of analytical results on machinereadable media received from a laboratory.

Estimated quantitation limit (EQL): The minimum concentration of a substance that can be reliably measured and reported within specified limits of precision and accuracy during routine laboratory operating conditions.

Field blank: See Blank.

Field duplicate: A second sample taken at the same time as the primary sample and sent to the laboratory for analysis as an unknown. The field duplicate is used to determine the precision of the entire sampling and analytical process.

Field sample: The material received at the laboratory to be analyzed that is contained in single or multiple containers and identified by a unique WSRC sample identification number. 
Frequency: The specified intervals between samples in which quality control samples or standards must be analyzed during an analytical run.

Groundwater: Water in a saturated zone or stratum beneath the surface of land.

Half-life: The time required for one-half of the initial number of radioactive nuclei of a specific isotopic species to undergo radioactive decay.

Holding time: The maximum amount of time allowed for samples to be held from sample collection to laboratory analysis.

Independent standard: A laboratory-prepared standard solution that is composed of analytes from a different source than those used in the standards for the initial calibration.

Initial calibration: The analysis of standards containing varying concentration levels of the analytes of interest in order to establish the ratio of concentration vs. response across the working range of the analytical technique. The initial calibration is used to define the linearity and dynamic range of response of the detector to the target analytes.

Initial calibration blank (ICB): A blank analyzed immediately after the initial calibration verification but before the analytical run to detect carryover contamination.

Initial calibration verification (ICV): The analysis of one or more standards immediately after the initial calibration but before the analytical run to verify that the initial calibration was valid.

Instrument detection limit (IDL): The minimum concentration of an analyte that can be measured and reported with $99 \%$ confidence that the analyte concentration is greater than zero. It is determined from analysis of a deionized water blank containing the analyte.

Interference check sample (ICS): Two solutions, one consisting of interferents only (ICSA) and one consisting of interferents mixed with the analytes (ICSAB), that are analyzed consecutively to verify the interelement and background correction factors for inductively coupled plasma metal analyses.

Interferents: Substances that affect the analysis for the element of interest.

Interlaboratory comparison: The comparison of results from split samples analyzed by two laboratories.

Internal standard: A chemically inert compound not expected to occur in an environmental sample that is added to a sample prior to analysis; it is used as an instrument response check.

Intralaboratory comparison: The comparison of duplicate results from a single sample analyzed by a laboratory.

Isomer: One of two or more chemical substances having the same elementary percentage composition and molecular weight but differing in structure and properties.

Data Summary Report for the 1997 Semiannual Tritium Survey for Fourmile Branch and the F- and H-Area Seeplines (WSRC-TR-97-00414) 
Isotope: One of a number of specific atoms with identical atomic numbers but with discrete atomic weights, or similarly specific atoms whose nuclei have the same number of protons but different numbers of neutrons.

Laboratory control sample (LCS): A control sample of known composition. Aqueous and solid laboratory control samples are analyzed using the same sample preparation, reagents, and analytical methods employed for the samples received.

Laboratory data records review (LDRR): The investigation of technical data validation issues that are not adequately addressed by the computer checking of EDDs, the review of the analytical narratives, and the review of the COC forms. The review is conducted at the laboratory using the laboratory's instrument logs, raw analytical data, and other pertinent documentation.

Laboratory duplicate: A second aliquot of a homogenized sample that is analyzed as an individual sample, using the same procedure. This duplicate is used to determine the precision of the method.

Laboratory ID: The identifier assigned by the laboratory for its internal use during the analytical process.

Linear range, linear dynamic range: The concentration range over which the calibration curve remains linear.

Lowest practical quantitation limit (LPQL): The lowest concentration of an analyte that can be reliably achieved within specified limits of precision and accuracy during routine laboratory operating conditions.

Matrix: The predominant material of which the sample to be analyzed is composed. For the purpose of this document, a sample matrix is either water or soil/sediment.

Matrix interference: The influence of the sample matrix or sample components upon the ability to quantitatively measure compounds in environmental samples.

Matrix spike/matrix spike duplicate: A first and second aliquot of a matrix fortified (spiked) with a known quantity of analyte(s) and subjected to the entire analytical procedure in order to determine the appropriateness of the method for the matrix by measuring accuracy (recovery) and precision (relative percent difference).

Maximum contaminant level (MCL): The maximum permissible level of a contaminant in a specified medium.

Mean relative difference (MRD): The average of the absolute difference of the results from two laboratories for the $i^{\text {th }}$ sample that is expressed as a percentage of the mean of both laboratories.

Method blank: See Blank.

Method detection limit (MDL): The minimum concentration of an analyte that can be measured and reported with $99 \%$ confidence that the analyte concentration is greater than zero. It is determined from analysis of a sample in a given matrix containing the analyte. 
Minimum detectable activity (MDA): The smallest quantity of a radionuclide that can be detected in a sample with a $95 \%$ confidence level.

Nuclide: General term applied to all isotopes of all elements including stable and radioactive forms. Nuclides are not considered isotopes; rather, a given nuclide is characterized by the number of neutrons and protons contained in the atomic nuclei of that species.

Null hypothesis: A statement that can be tested statistically to determine if there is a significant difference between duplicate/split results.

Parts per billion (ppb)/Parts per million (ppm): Units commonly used to express low concentrations of contaminants. For example, 5 micrograms of benzene in 1 kilogram of soil is $5 \mathrm{ppb}$; milligrams of nitrate in 1 liter of water is $3 \mathrm{ppm}$.

Percent moisture: An approximation of the amount of water in a soil/sediment sample determined by drying an aliquot of sample at a specified temperature until constant weight is achieved.

Percent recovery: A measure of recovery that is calculated as the measured value relative to the true value, expressed as a percent.

Percent solids: The proportion of solid in a soil/sediment sample determined by the percent moisture procedure.

Performance evaluation sample: A sample of known composition that may be provided by the EPA or WSRC for laboratory analysis that is used to evaluate laboratory performance.

PicoCurie (pCi): The unit of radiation equivalent to $3.7 \times 10^{-2}$ disintegrations per second.

Precision: The agreement or repeatability of a set of replicate results among themselves, usually expressed in terms of the deviation of a set of results from the arithmetic mean. Precision may be qualified in terms of possible sources of variability, replicability, repeatability, and reproducibility.

Preparation log: An official record of the sample preparation.

Preservative: A chemical compound added to a sample or a physical process (such as cooling) to prevent or slow decomposition or degradation of a target analyte. Physical and chemical preservation may be used in tandem to prevent sample deterioration.

Primary laboratory: The laboratory having a contract with WSRC to perform a specific set of analyses for field-generated samples, duplicates, and blanks. A primary laboratory may subcontract this work to other laboratories.

Qualifier: A code used to convey additional information about an analytical result. See the following examples.

- A Result Qualifier is used to indicate the usability of the result for regulatory purposes.

Data Summary Report for the 1997 Semiannual Tritium Survey for Fourmile Branch and the F- and H-Area Seeplines (WSRC-TR-97-00414) 
- An Analysis Qualifier is used to describes analytical conditions which apply to the datum. Analysis qualifiers are included for information only.

- A Bias Qualifier is a code used to indicate whether a result may overestimate or underestimate the true value. It also may be used to indicate poor precision.

See Appendix $D$ for additional information and the specific qualifiers used.

Qualitative analysis: An analysis to determine the presence or absence of a target analyte.

Quality assurance plan: The documented data quality objectives and the actions to be performed to meet those objectives.

Quality control (QC): The performance of actions that provide a way to control and measure the characteristics of measurement equipment and processes to meet the established data quality objectives.

Quantitative analysis: An analysis to measure or determine the amount of a target compound or analyte within the limits of defined precision and accuracy requirements.

Radionuclide: Any radioactive isotope of an element.

Range: The difference between the maximum and minimum values within a set of values.

RCRA Facility Investigation/Remedial Investigation (RFI/RI) program: The EPAregulated investigation of a solid-waste management site, including CERCLA and hazardous-substance regulations, with regard to its potential impact on the environment.

Recovery: A determination of accuracy of the analytical procedure made by comparing measured values for a reference or fortified (spiked) sample against the known true reference or spike values.

Reference detection limit (RDL): The detection limit chosen to allow comparison of multiple analyses with different detection limits. For this report, the individual detection limits of at least $90 \%$ of the analyses are less than the reference detection limit.

Relative percent difference (RPD): A measure of precision that is calculated as the absolute value of the difference between two results, relative to their arithmetic mean, expressed as a percent.

Reporting limit: The value reported in the result field when an analyte is not detected.

Reproducibility: The precision of measurements of the same sample at different laboratories using the same protocols.

Resolution: The degree to which two signal peaks are separated. Resolution is calculated by dividing the height of the valley between the peaks by the height of the peak being resolved, multiplied by 100 .

Resource Conservation and Recovery Act (RCRA): A 1976 federal law that established a regulatory system to define and track hazardous wastes from the time of generation to disposal. The law requires safe and secure procedures to be used in treating, transporting, storing, and disposing of hazardous substances.

Data Summary Report for the 1997 Semiannual Tritium Survey for Fourmile Branch and the F- and H-Area Seeplines (WSRC-TR-97-00414) 


\section{Rinsate blank: See Blank.}

Run: A continuous analytical sequence consisting of prepared samples and all associated quality control measurements.

Sample: A portion of material to be analyzed that is contained in single or multiple containers and identified by a unique sample number.

Sample ID: A unique identification number designated by WSRC for each sample. The WSRC sample ID appears on the sample chain of custody that documents information on that sample.

Sample matrix: All of the chemical components and physical characteristics of a sample other than the parameter of interest.

Sample-specific estimated quantitation limit (ssEQL): The estimated quantitation limit multiplied by factors of concentration, dilution, aliquot size, and percent solids.

Sediment: The unconsolidated inorganic and organic material that is suspended in and being transported by surface water or that has settled out and has deposited into beds.

Self-absorption: The internal absorption of radiation by material in which radioactive atoms are located.

Sensitivity: The ability of a measurement system to detect and accurately quantitate a parameter at a critical level within a specific sample matrix. The critical level may be a regulatory maximum contaminant level (MCL), MDA, or risk-based exposure level.

Significance of probability: The probability of observing a statistical value as significant as, or even more significant than, the value actually observed.

Soil: All unconsolidated materials normally found on or near the surface of the earth including, but not limited to, silts, clays, sands, gravel, and small rocks.

Solvent: Liquid that is capable of dissolving another substance.

Split sample: A second aliquot of a sample, generated in the field, that is sent to a secondary laboratory for analysis; a split sample serves as a quality control check.

Standard deviation: The measurement of dispersion about a mean value of a series of observations expressed in the same units as the mean value.

Surface water: All water that is open to the atmosphere and subject to surface runoff.

Surrogate: A chemically inert organic compound similar in composition and test performance to an analyte of interest added to samples prior to analysis as a quality control check.

Surrogate recovery: A quality control measurement to monitor unusual matrix effects, gross sample processing errors, etc. It is evaluated for acceptance by determining whether the measured concentration falls within the statistical acceptance limits established by the laboratory.

Target analyte list (TAL): The list of inorganic analytes required by CERCLA.

Data Summary Report for the 1997 Semiannual Tritium Survey for Fourmile Branch and the F- and H-Area Seeplines (WSRC-TR-97-00414) 
Target compound list (TCL): The list of organic analytes required by CERCLA.

Technical holding time: The storage time allowed between sample collection and sample analysis when designated preservation and storage techniques are employed. This is determined by the elapsed time in days from the date and time of collection to the date and time of sample preparation and analysis.

- Technical holding time $=($ sample analysis date and time - sample collection date and time).

Tentatively identified compound (TIC): Chromatographic peak in volatile and semivolatile fraction analysis that is not a target analyte, surrogate, or internal standard.

Time: When required to record time on any deliverable item, time is expressed as military time, i.e., on a 24 -hour clock.

Toxicity characteristic leaching procedure (TCLP): An analytical extraction procedure used to determine the mobility of both inorganic and organic analytes present in solid, liquid, and multiphasic wastes.

Tracer: A quantity of a unique radioisotope of the same element added to a sample, chemically prepared, or separated and counted. The quantity of tracer measured is compared to the quantity of target radioactive element measured, and the target quantity is calculated on the basis of unity with the tracer concentration.

Trip blank: See Blank.

Wet weight: The weight of a sample aliquot including moisture (undried). 